\title{
FORMAÇÃO DE EDUCADORES AMBIENTAIS E POTÊNCIA DE AÇÃO: UM ESTUDO DE CASO
}

\author{
CLÁUDIA COELHO SANTOS
}

\begin{abstract}
Dissertação apresentada à Escola Superior de Agricultura "Luiz de Queiroz", Universidade de São Paulo, para obtenção do título de Mestre em Recursos Florestais, com opção em Conservação de Ecossistemas Florestais.
\end{abstract}

PIR A C I C A B A

Estado de São Paulo - Brasil

Dezembro - 2002 


\title{
FORMAÇÃO DE EDUCADORES AMBIENTAIS E POTÊNCIA DE AÇÃO: UM ESTUDO DE CASO
}

\section{CLÁUDIA COELHO SANTOS}

Bióloga

Orientador: Prof. Dr. MARCOS SORRENTINO

\begin{abstract}
Dissertação apresentada à Escola Superior de Agricultura "Luiz de Queiroz", Universidade de São Paulo, para obtenção do título de Mestre em Recursos Florestais, com opção em Conservação de Ecossistemas Florestais.
\end{abstract}

PIR A CICABA

Estado de São Paulo - Brasil

Dezembro - 2002 


\section{Dados Internacionais de Catalogação na Publicação (CIP)}

DIVISÃO DE BIBLIOTECA E DOCUMENTAÇÃO - ESALQ/USP

Santos, Cláudia Coelho

Formação de educadores ambientais e potência de ação : um estudo de caso /

Cláudia Coelho Santos. - - Piracicaba, 2002.

$164 \mathrm{p}$.

Dissertação (mestrado) - - Escola Superior de Agricultura Luiz de Queiroz, 2002.

Bibliografia.

1. Avaliação da educação 2. Curso de especialização 3. Educação [estudo e ensino] 4. Educação ambiental 5. Formação de professores 6 . Mudança de atitude I. Título

CDD 370.71

"Permitida a cópia total ou parcial deste documento, desde que citada a fonte - $\mathrm{O}$ autor" 


\section{DEDICATÓRIA}

Dedico este trabatho i Camilla, Fiago, Poliana, Simone, Guitherme Gabiclas, sobrinhas e sobrinhos queridos, que me fazem acreditar a cada dia na forc a dos sontwos e das utofias.

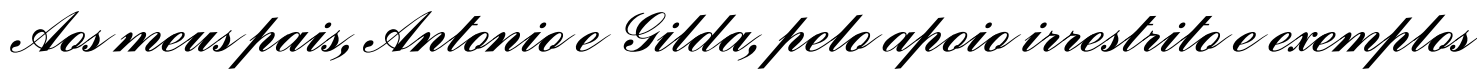
defore a, yana e nobreza de caraiter.

A

Telma, Solange, Marcos e Alex, imnäs e irmãos, pelo caninho e apoio.

Dedico, especialmente, is minhar avó Alice Coetho, pelo olhar brithante e repleto de esperanç a, de resistê ncia e, sobretudo, de amov. Pelo exemplo constante, inestrito e incondicional, de amor, de tolerância e de confianç a no ser humano. 


\section{AGRADECIMENTOS}

Ao Marcos pela orientação e, sobretudo, por ter-me permitido compartilhar de seus ideais de transformação.

À Prof. Eda Tassara, Prof. Carlos Rodrigues Brandão e Prof. Dálcio Caron , pelas valiosas contribuições no exame de qualificação e pela aprendizagem proporcionada pelo convívio.

À Raquel, ao Vitor e ao Japi, amizades preciosas que vieram junto com este mestrado, pelas inúmeras oportunidades de amadurecimento pessoal e profissional compartilhadas.

Aos amigos e amigas, também "estrangeiros em Pira", Andréia, Ana Paula B., Anderson, Valquíria, Aninha e Maria Cláudia, que tive o prazer de conhecer e conviver ao longo desse período.

Aos companheiros do Laboratório de Educação e Política Ambiental, Ana Paula, Isis, Flavia, Rita, Fábio, Marcos B., Mário, Valéria e Sandra pelas contribuições e incentivos.

Ao Alexandre Halle, do Departamento de Ciências Florestais, pelo incentivo, apoio e, especialmente, paciência nos momentos finais deste trabalho. 
À Valéria Lessa, por toda força, apoio e amizade que, mesmo à distância, foram fundamentais para a realização deste estudo.

Aos colegas do Departamento de Ciências Biológicas da Universidade Estadual do Sudoeste da Bahia, pelas experiências compartilhadas que resultaram em amadurecimento profissional.

Aos especialistas egressos do Curso de Especialização em Educação para Sociedades Sustentáveis, pela atenção e disposição na prestação das informações e dados utilizados na pesquisa.

À minha família, pais, irmãos e irmãs, sobrinhos e sobrinhas, pelo carinho 


\section{SUMÁRIO}

Página

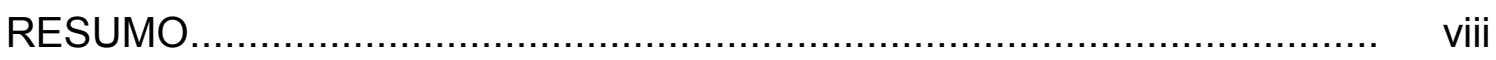

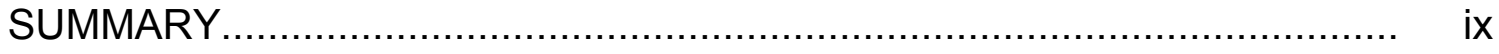

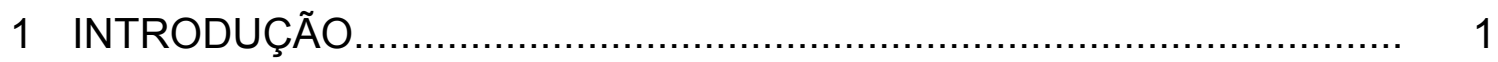

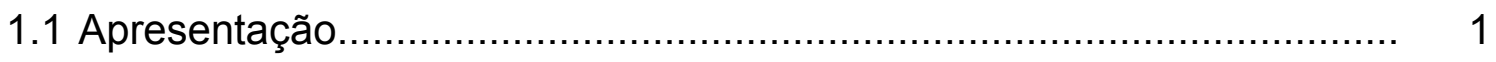

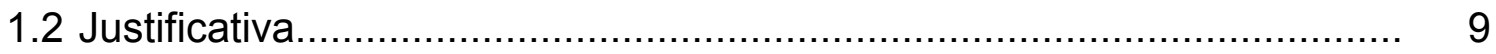

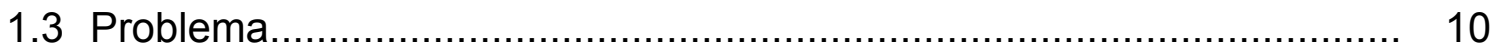

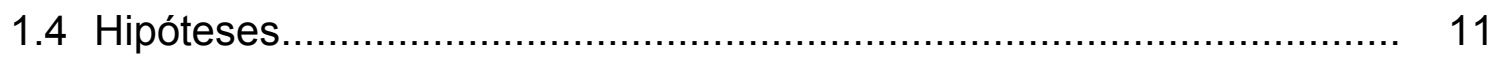

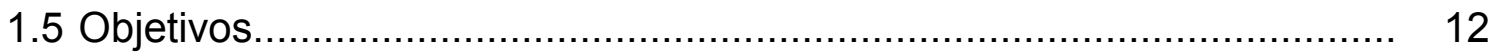

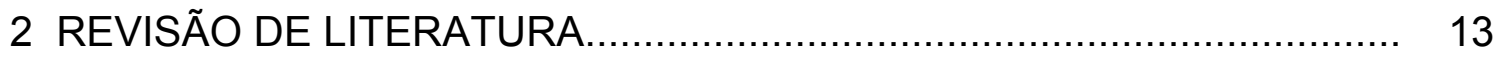

2.1 A sociedade em transformação: desafios à emancipação social............ 13

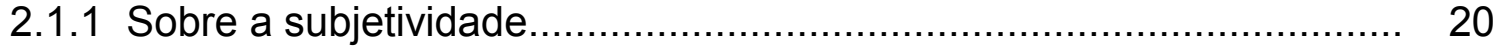

2.2. A Potência de Ação : uma leitura preliminar de Espinosa.................... 23

2.3 Educação Ambiental para Sociedades Sustentáveis ........................ 39

2.4 Universidade e emancipação social......................................... 43

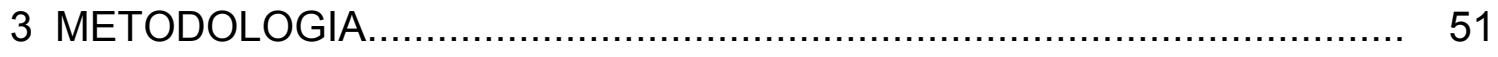

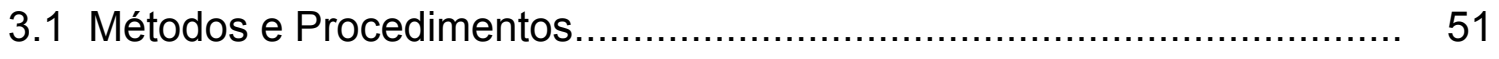

3.1.1 Pesquisa Qualitativa....................................................... 56

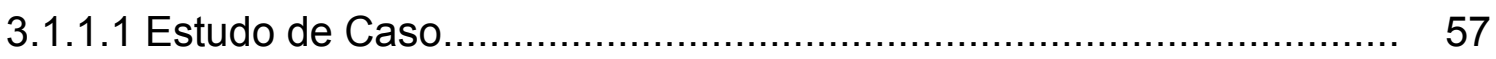

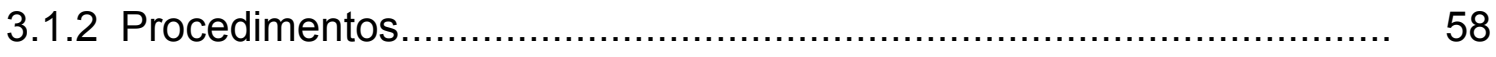




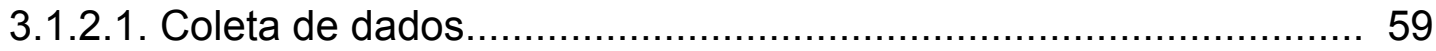

3.1.2.2 Análise e interpretação dos dados........................................... 60

3.2 Cenário de estudo................................................................. 62

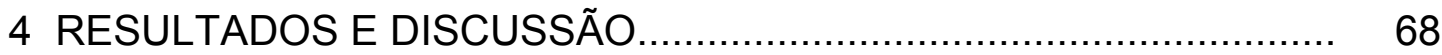

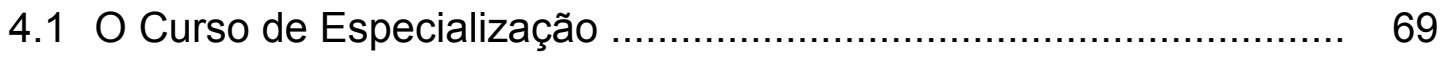

4.2 Sobre o Curso de Especialização................................................ 79

4.2.1 Percepção da proposta educativa............................................... 79

4.3 O impacto no cotidiano............................................................. 104

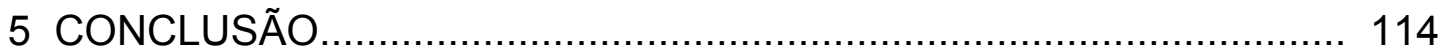

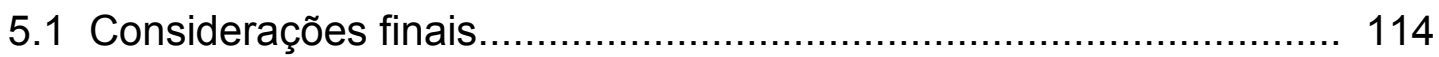

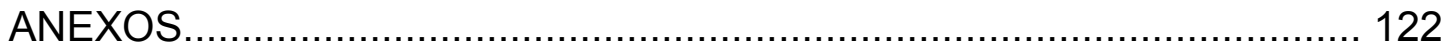

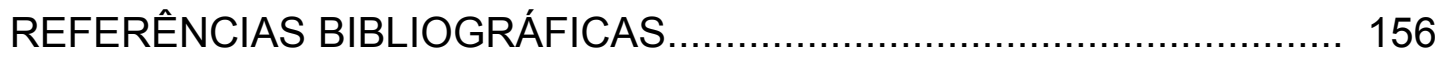




\title{
FORMAÇÃO DE EDUCADORES AMBIENTAIS E POTÊNCIA DE AÇÃO: UM ESTUDO DE CASO
}

\author{
Autora: CLÁUDIA COELHO SANTOS \\ Orientador: Prof. Dr. MARCOS SORRENTINO
}

\section{RESUMO}

Este estudo foi realizado com o objetivo de contribuir para a produção de conhecimentos que visem a constituição, consolidação e promoção de processos educacionais voltados à potencializar os sujeitos para uma ação comprometida com a sustentabilidade socioambiental. Assim, utilizando elementos da pesquisa qualitativa e procedimentos do estudo de caso, buscouse identificar, no Curso de Especialização em Educação para Sociedades Sustentáveis, desenvolvido pela Universidade Estadual do Sudoeste da Bahia, campus de Jequié, os elementos que poderiam estimular mudanças de atitude e valores no sentido da transformação social, refletindo no incremento da potência dos sujeitos envolvidos. A pesquisa apresenta aspectos que devem ser contemplados em um programa de Educação Ambiental. Processos pautados na autonomia dos educandos, no diálogo entre os envolvidos e na prática reflexiva, podem contribuir para a formação de educadores críticos, competentes tecnicamente e comprometidos ética e politicamente com as questões ambientais. 


\title{
FORMATION OF ENVIRONMENTAL EDUCATORS AND THE POTENTIAL OF ACTION: A STUDY CASE
}

\author{
Author: CLÁUDIA COELHO SANTOS \\ Adviser: Dr. MARCOS SORRENTINO
}

\section{SUMMARY}

This study was carried out aiming contributing for the production of knowledge viewing constitution, consolidation, and promotion of educational processes related to powering the subjects for an action committed with the social and environmental sustainability. Thus, in the Specialization Course on Education for Sustainable Societies developed by State University of Southeast Bahia, campus Jequié, and by using the elements of a qualitative research and proceedings of this study case, the identification of elements that could promote changes of values and attitudes toward the social transformation through increasing the power of the subjects involved. The research shows points that must be presented in Environmental Education programs. Processes based on the autonomy of the students, on the dialog between the involved ones and the reflexive practice can contribute for the formation of critical, technically competent, and committed educators ethically and politically active toward the social-environmental matters. 


\section{INTRODUÇÃO}

\begin{abstract}
"Na travessia da vida muitas vezes percorremos um caminho que contém, antes que um ponto de chegada, um percurso. É neste caminhar que se entrelaçam várias experiências em que vozes entrecruzam-se, diversos olhares às vezes contraditórios, às vezes ambíguos, aliam-se à nossa vida, dando-nos uma convicção de trabalho, de compromisso com a ciência, com o conhecimento adquirido e a adquirir".
\end{abstract}

Ivanise Leite

\subsection{Apresentação}

A presente dissertação representa mais do que uma pesquisa acadêmica. Ouso afirmar que a mesma insere-se no universo dos projetos inéditos viáveis ${ }^{1}$ que buscam uma utopia concreta de transformação da sociedade, neste caso, através de processos educativos fundados na participação e emancipação humana. Nasceu desta inquietação, passando da curiosidade ingênua à curiosidade epistemológica ${ }^{2}$ e, nesse sentido, socializar

\footnotetext{
${ }^{1}$ Freire, Ana Maria (1992 e 2000).

${ }^{2}$ A curiosidade epistemológica é, para Paulo Freire, aquela que ao viabilizar a tomada de distância do objeto, transcende os limites da cotidianeidade na qual nossa mente não opera epistemologicamente. Segundo ele a curiosidade epistemológica, própria da "consciência crítica, aquela que não se satisfaz com
} 
minhas reflexões é um desafio à autoconsciência de que muitos saberes encontram-se ainda em construção e de que este estudo colocou-me frente a novas indagações, novas reflexões o que exige novas buscas.

Nesse percurso tive a oportunidade de dialogar com vários interlocutores, com os quais muito tenho aprendido, dentre estes destaco Boaventura de Sousa Santos, Paulo Freire, Marcos Sorrentino, Eda Tassara e, por que não citar, Ernesto Che Guevara, agente revolucionário crítico e auto-reflexivo, para quem, assim como para Marx, "a ação educativa (...) carrega consigo a garantia político-ética de não apenas entender o mundo, mas de transformá-lo" (McLaren, 1999, p.134).

Contudo, não tenho a pretensão de falar como uma profunda conhecedora do assunto e sim, a partir da perspectiva de uma bióloga envolvida há alguns anos com a educação e com a militância política, trajetória esta que me conduziu para a educação ambiental e ao questionamento sobre as suas possibilidades de contribuir para a reinvenção do futuro ${ }^{3}$. Assim, considero pertinente falar desta trajetória que não é individual, mas coletiva, forjada a partir dos encontros e desencontros vividos em espaços e tempos distintos, e que foi determinante para os contornos deste estudo.

Formada em Biologia, a minha aproximação com a Educação Ambiental (EA) aconteceu quando ingressei como professora da área de Zoologia, no então Departamento de Ciências Exatas e Naturais - DCEN (dividido, posteriormente, originando aos Departamentos de Ciências Biológicas e de Química e Exatas - DCB e DQE, respectivamente), da Universidade Estadual do Sudoeste da Bahia, no campus de Jequié-Ba. Nesse período, além das aulas de disciplinas da área de Zoologia nos cursos de graduação - Licenciatura Curta em Ciências e Plena em Biologia, atuei como colaboradora de um projeto relacionado à Educação Ambiental no Ensino de Ciências.

as aparências" (1979, p.40) busca a compreensão dos problemas em maior profundidade e é relacionada ao tão difícil quanto prazeroso ato de estudar.

${ }^{3}$ Termo utilizado por Boaventura de Sousa Santos $(1997,2000)$. 
Contudo, percebi que o mencionado projeto partia de uma compreensão de EA vinculada estreitamente com conteúdos de Ecologia, o que não atendia aos meus anseios de uma atuação mais politizada. Assim, dediquei-me à leituras diversas na área ambiental, no intuito de encontrar o meu próprio caminho no interior da EA, de modo a conciliar a perspectiva da defesa do meio natural aos meus anseios de militância política.

Entre julho de 1996 e janeiro de 1998 cursei a Especialização em Metodologia do Ensino de Biologia e, dentre as muitas contribuições que esse curso trouxe à minha prática profissional, cabe registrar o encontro com a professora Terezinha Fróes Burnham e as suas idéias sobre complexidade e multirreferencialidade. Além disso, possibilitou uma fundamentação filosófica, teórica e metodológica mais profunda sobre a educação em geral.

Nessa época iniciaram-se as atividades do Programa de Apoio ao Ensino Fundamental da Região Sudoeste da Bahia, conhecido pela comunidade acadêmica como SEF, financiado pela Secretaria do Ensino Fundamental do Ministério de Educação e Cultura e que objetivava a capacitação de professores da rede pública municipal e estadual de ensino de seis municípios da região sudoeste do Estado- Jequié, Itapetinga, Vitória da Conquista, Itagi, Itarantim e Anagé.

Considero que o SEF constituiu-se em uma contribuição extremamente importante para a institucionalização do tema "Meio Ambiente", assim como da perspectiva interdisciplinar, no interior da universidade, visto que foi o primeiro projeto institucional a contemplar essa área, com tal opção metodológica e filosófica. Assim, possibilitou o incremento de um processo ousado e pioneiro ao reunir cerca de quarenta docentes e quarenta alunos de áreas distintas, propondo a constituição de uma verdadeira "comunidade de aprendizagem".

O programa foi estruturado de maneira a possibilitar que os integrantes de cada área - professores e alunos - contassem com a colaboração de um consultor que os auxiliasse na elaboração do plano de ação, voltado à capacitação dos professores do ensino fundamental de maneira disciplinar, 
porém sem perder de vista o objetivo final que era a consolidação de uma ação interdisciplinar. Assim, Marcos Sorrentino foi convidado para ser o consultor da área de Meio Ambiente do projeto SEF, que era coordenada por mim.

Durante os dois anos de funcionamento do SEF foram realizados inúmeros encontros que serviam à discussão e elaboração das propostas educativas de cada área; avaliação das ações e da própria estrutura administrativa e concepção do programa; capacitação dos participantes professores e alunos - em temas de interesse do grupo, com a mediação de profissionais de outras instituições; articulação das áreas para implantarem no campo as ações interdisciplinares. Hoje percebo que essa experiência promoveu a emergência de uma comunidade interpretativa na perspectiva apontada por Boaventura Sousa Santos (1997), na medida em que possibilitou um encontro bastante produtivo e prazeroso entre pessoas que aceitaram o desafio de aprender e construir juntos uma outra forma de fazer educação.

Considero, ainda, que a aprendizagem proporcionada durante esse processo foi fundamental para o caminho dado ao projeto político-pedagógico e à proposta curricular do novo curso de Ciências Biológicas que, além da licenciatura, foi implementado como bacharelado em 1998. Foram incorporadas disciplinas como Ecologia Humana, Educação e Meio Ambiente, Bioética, Educação e Orientação para a Sexualidade, além da perspectiva de abordagem interdisciplinar. Nesse momento, optei por transferir-me da área de Zoologia uma vez que atuando na área não conseguia unir a "sensibilidade social e eficiência pedagógica" , essenciais ao reencantamento da educação na visão de Assmann (1999, p.34). Assim, fui para a área de Ecologia e sou responsável pelas disciplinas Ecologia Humana para o curso de Biologia e Educação e Meio Ambiente nos cursos de Biologia e Pedagogia.

É importante registrar que nesse período (1994 a 2001) exerci atividades acadêmicas relacionadas ao ensino e à extensão, assim como atividades administrativas (Vice-direção do DCEN, Coordenação Setorial de Laboratórios e Direção do DCB) e sindicais (Secretaria e Vice-Presidência Regional, em dois 
mandatos - cerca de quatro anos, da Associação de Docentes da UESB ADUSB). A participação nesses diferentes espaços contribuiu sobremaneira para a compreensão da estrutura universitária, tanto nos aspectos acadêmicos quanto nos relacionados à questão administrativa e à política de ensino superior, a partir de duas visões e ou vivências diferenciadas: a burocracia administrativo-acadêmica e a militância no movimento docente.

O engajamento político e ideológico e a percepção da importância da universidade enquanto instância geradora de um saber que, além de atender às demandas impostas pelo mercado, deveria pautar-se em ações de ensino, pesquisa e extensão que resultassem em uma prática educativa comprometida, ética e politicamente, com a transformação social foram determinantes para a busca da consolidação de uma parceria entre a USP, através do Prof. Marcos Sorrentino e a UESB, através do DCB.

Após dois anos de discussão conseguiu-se a formalização da parceria, através da assinatura de um convênio entre a USP e a UESB, que previa a realização de cursos de especialização voltados à formação de educadores ambientais, que deveriam capacitar os referidos agentes de sustentabilidade. Assumi a coordenação do convênio pela UESB e elaborei, com o auxílio do Prof. Marcos, a proposta do curso de Especializacão em Educação para Sociedades Sustentáveis realizado entre fevereiro de 2000 e fevereiro de 2001, sendo que o mesmo também ficou sob a minha coordenação.

Este período, de realização do curso, foi extremamente conturbado. Pelas inquietações e angústias geradas no decorrer do processo e pelo momento vivido na UESB: conflitos e desencontros na direção do DCB e uma greve das universidades estaduais da Bahia, que durou cerca de três meses. Foi nessa conjuntura que resolvi fazer o mestrado.

Os constantes encontros, antes e durante o mestrado, entre os integrantes do coletivo que planejou e desenvolveu os cursos ( de Feira de Santana e de Piracicaba) foram momentos de uma fecunda reflexão, apresentando a cada dia uma nova inquietação, um novo desafio a ser 
enfrentado. E, a partir desses diálogos, cheguei à conclusão de que a decodificação do conceito de potência de ação seria essencial para a compreensão das possibilidades da proposta educativa formulada e implementada nos cursos atingir os seus ideais de consolidação de uma cultura participativa e emancipatória.

Assim, a presente pesquisa enfoca as contribuições que o campo da Educação Ambiental pode trazer para o estabelecimento de processos educativos emancipatórios que possibilitem o incremento na potência de ação, individual e coletiva, visando a melhoria do meio ambiente e da qualidade de vida, a partir da análise da proposta educacional do curso de Especialização em Educação para Sociedades Sustentáveis, implementado pela Universidade Estadual do Sudoeste da Bahia, campus de Jequié.

Conforme dito anteriormente, a minha intenção aqui é apresentar algumas reflexões que emergiram a partir das leituras e estudos de diferentes autores e sua relação com o trabalho de campo. Ivanise Leite $(1999$, p.10) sintetiza, com muita precisão, o que representa essa dissertação:

"É interessante perceber o paradoxo entre o aliviado término de uma etapa da pesquisa, e a ansiosa e sufocada retomada da etapa seguinte. Ao atuar-se no passado, tece-se um destino, origem deste trabalho. Ele é fruto de um trabalho vivido, refletido, que foi se instituindo na produção do universo científico com momentos de recusa e de esperança, de busca e de recuo, de encontros e desencontros, de certezas e incertezas, que são muitas, de contradições, e de confrontos, mas de busca incessante".

Durante os dois anos de pesquisa muitas coisas mudaram, o próprio conceito norteador das reflexões e das buscas - potência de ação - foi incorporado no decorrer do percurso mas, apesar dos desencantos e da frustração pela impossibilidade de apresentar reflexões melhor embasadas e, a 
despeito das lacunas e ausências que permeiam esse texto, o desvelamento do significado deste termo e o entendimento da sua relação com a construção do projeto alternativo da sociedade desejada têm um significado muito especial para mim.

Para além do entendimento do significado do conceito de potência de ação, meus questionamentos apontavam a necessidade da criação de instrumentos metodológicos que pudessem viabilizar um processo educativo comprometido com uma concepção emancipatória de educação. Nesse contexto, a questão que motivou o desenvolvimento dessa pesquisa traduz-se na seguinte pergunta: Quais elementos devem estar presentes em uma proposta educacional que se proponha ao aumento da potência de ação das pessoas como forma de consolidação de sociedades sustentáveis?

Para tentar responder a essa questão a pesquisa objetivou identificar os indicadores que traduzem o incremento na potência de ação dos indivíduos e de que forma isso é contemplado no curso de especialização objeto deste estudo de caso. Para tanto, aventurei-me em incursões a diferentes áreas de conhecimento, como a filosofia, a psicologia e a sociologia, procurando desvelar em que concepção de homem, de sociedade e de mundo se apoia o projeto alternativo de sociedade.

As reflexões reunidas aqui organizam-se da seguinte forma:

Capítulo 1 - trata-se da "Introdução" destinada a apresentação dos motivos que conduziram à realização dessa pesquisa. Assim, tem-se a justificativa, a apresentação do problema, das hipóteses e dos objetivos que a nortearam.

Capítulo 2 - tem-se a "Revisão de Literatura" que dará subsídio à análise dos dados do campo. Baseia-se, essencialmente, nas idéias do sociólogo português Boaventura de Sousa Santos e de autores que convergem com sua perspectiva de emancipação social e reinvenção do futuro, cerne do projeto que 
origina essa pesquisa. Em seguida busco apresentar o conceito de potência de ação, baseada na obra do filósofo holandês Baruch Espinosa, principalmente a partir da leitura de Marilena Chauí, e a sua possível relação com as propostas defendidas por uma EA emancipatória.

Capítulo 3 - "Metodologia", traz uma reflexão sobre a concepção de ciência que norteou a pesquisa, assim como a apresentação dos métodos e procedimentos adotados.

Capítulo 4 - "Resultados e Discussão", trata-se do desvelamento dos contextos da formação dos educadores ambientais por meio da interpretação das suas falas, na tentativa de apreender em sua prática cotidiana as contribuições do curso. Por meio da análise das entrevistas e dos cadernos de campo/diário de bordo procuro interpretar as suas falas, relacionando-as ao contexto teórico pesquisado.

Capítulo 5 - muito embora esse estudo não tenha a pretensão de ser conclusivo encontram-se, neste item, reflexões sobre os resultados da pesquisa e considerações que poderão contribuir para a continuidade da busca aqui iniciada.

Concordando com Leite (1999, p.10) quando afirma que "a construção do conhecimento teórico não ocorre de forma imediata, mas num processo de múltiplas aproximações frente ao objeto de estudo", credito as lacunas existentes nesse texto à insuficiência de tempo para apreender os sentidos e significados contidos nas mensagens de cada autor lido e a sua relação com o processo educativo, objeto de estudo.

Tendo ciência de que essa foi uma primeira etapa deste percurso pretendo continuar, durante o curso de doutorado a ser iniciado em março de 2003, os estudos e as reflexões sobre as propostas político-pedagógicas implementadas nesses cursos e as possibilidades que as mesmas representam 
de promoverem a emergência e a consolidação de uma outra sociedade, pautada em uma cultura emancipatória.

\subsection{Justificativa}

Um dos aspectos mais representativos do momento atual é a dualidade que o caracteriza. No limiar de um novo século vivemos em um terreno fronteiriço entre velho e novo mundo. Como assinala Morin (2000, p.41) "um que está prestes a morrer, mas que não morreu ainda, e outro, que quer nascer, mas que não nasceu ainda". Boaventura de Sousa Santos $(1997,2000)$ afirma que atravessamos um período de transição de paradigmas e, como em toda transição, não sabemos bem onde estamos, tampouco para onde vamos.

Contudo, esse é um momento de grandes desafios, de chamamento à criatividade e à resistência, nunca de submissão ou rendição aos arautos do conformismo e da passividade. O discurso do "fim da história", do "fim da ideologia" ou ainda o "fim das utopias", defendido por Francis Fukuyama (1992), amplamente difundido na última década com o intuito de fortalecer a idéia de que as condições oferecidas pelo neoliberalismo, no presente, serão as únicas com possibilidade de continuidade no futuro, objetiva a despolitização da sociedade, a acomodação e passividade frente a um futuro já dado.

$\mathrm{Na}$ rejeição e na crítica do presente, com sua conformação injusta e excludente, a "idéia de utopia aqui implícita persistiu, resistindo às certidões de óbito justamente pela sua obstinação em contradizer o esboço de um mundo 'acabado' tendo suscitado um novo e apaixonado debate sobre o rumo da nossa civilização " (Dias, 2000). Tassara (1997, p. 40) afirma que caberia à Educação Ambiental, nesse contexto, "o papel de reencontrar o fio de Ariadne, ligando o presente ao futuro utópico".

Mas, sob tal perspectiva, como a EA alimentaria esses processos? 
Tassara (1997, p. 48) propõe "a implementação intencional e planejada de instâncias de reflexividade" , ou seja, a implementação de espaços de locução, coerentes com um projeto de construção de um novo ethos social, que formem sujeitos políticos capazes de agir criticamente na sociedade, com base em valores democráticos, solidários e emancipatórios.

O curso de especialização em Educação para Sociedades Sustentáveis, desenvolvido pela Universidade do Sudoeste da Bahia - UESB, objeto desta pesquisa, buscou implementar uma proposta político-pedagógica que atendesse a esses ideais e princípios. Porém, como em todo processo inovador, construído sobre bases teórico-metodológicas ainda inconsistentes, conflitos e contradições emergem no seu decorrer e, dependendo de como os processos são elaborados e conduzidos, podem levar à incorporação de ações e atitudes transformadoras ou à acomodação e à passividade.

Nesse contexto, acredito que a análise de um programa de EA, voltado à formação de educadores ambientais em uma perspectiva educacional participativa e emancipatória, poderá contribuir tanto para a compreensão, quanto para a formulação de políticas públicas nas áreas de educação e meio ambiente. Contribuirá, ainda, para a consolidação do campo ainda emergente da EA com o aporte de novos conhecimentos.

\subsection{Problema}

A proposta desse estudo surgiu da indagação de como a EA poderia contribuir para a transformação da sociedade. Compreende-se que tal contribuição passa pela implementação de processos educacionais que promovam uma interação crescente entre os(as) educadores(as) e os(as) educandos(as) e destes com o meio social, em um ambiente de aprendizagem pautado na superação das práticas pedagógicas tradicionais, como forma de promover o seu empoderamento. 
Neste sentido, essa pesquisa visa investigar quais aspectos devem ser contemplados em um programa de formação de educadores ambientais destinado ao incremento da potência de ação dos(as) educando(as), em uma perspectiva de transformação social. Dessa forma, utilizaremos como objeto de análise e reflexão o curso de Especialização em Educação para Sociedades Sustentáveis desenvolvido na Universidade Estadual do Sudoeste da Bahia.

Assim, buscamos respostas às questões abaixo:

1. Quais indicadores podem revelar que houve o incremento na potência de ação dos sujeitos que participaram do curso?

2. Quais princípios, conceitos, referenciais e procedimentos embasaram a proposta educacional do curso de Especialização em Educação para Sociedades Sustentáveis?

3. Considerando os indicadores identificados, em que medida o referido curso contribuiu para que os sujeitos se tornassem mais potentes para a ação?

4. Quais elementos devem estar presentes em uma proposta educacional que proponha-se ao aumento da potência de ação das pessoas, como forma de consolidação de sociedades sustentáveis?

\subsection{Hipóteses}

1. O curso de especialização, nos moldes em que foi implementado, estimulou o envolvimento crítico e uma ação propositiva e transformadora dos participantes.

2. O curso em foco contribuiu para o aumento da potência de ação dos indivíduos e dos coletivos envolvidos.

3. A proposta político pedagógica do curso de especialização em foco constitui-se em um processo educacional deflagrador de ações emancipatórias, portanto transformadoras, na medida em que potencializa os indivíduos a se verem como sujeitos de sua própria história. 


\subsection{Objetivos}

\subsubsection{Geral}

Contribuir para a produção de conhecimentos que visem a constituição, consolidação e promoção de processos educacionais voltados à potencializar os sujeitos para uma ação comprometida com a sustentabilidade sócioambiental .

\subsubsection{Específicos}

i) Analisar os possíveis nexos de causalidade entre a potência de ação individual e coletiva e processos educacionais voltados à construção de sociedades sustentáveis.

ii) Contribuir para a avaliação e o planejamento de cursos de formação de educadores ambientais voltados para a construção de sociedades sustentáveis; iii) Identificar e analisar os aspectos que interferiram na formação de educadores ambientais que formulem e implementem projetos de intervenção educacional voltados à formação de agentes locais de sustentabilidade.

iv) Identificar e analisar os princípios que embasaram a proposta do curso. 


\section{REVISÃO DE LITERATURA}

\subsection{A sociedade em transformação: desafios à emancipação social}

O século XXI inicia-se em meio a grandes e céleres transformações nos campos político, econômico, social, cultural e ambiental evidenciados pelos seguintes aspectos, dentre outros: a difusão de uma nova escala de valores; o fortalecimento do capitalismo transnacional; o conflito entre a globalização e a cultura regional; a cultura da submissão e a erosão das subjetividades (Santos, 1997, 2001; Ianni, 1997; Carvalho, 2001).

Essa "nova ordem mundial", segundo Edgard de Assis Carvalho (2001):

"inundou de desigualdades todas as sociedades sem distinção de longitude ou latitude aumentando os sem-emprego, os sem-terra, os sem-teto. Todas essas ausências sociais (...) repercutem a cada dia na pauperização do trabalho e da vida como um todo se deixadas a seu bel prazer conterão três possibilidades: ou o sistema se autodestrói por si próprio ou se recompõe por soluções paliativas, ou se nega por uma utópica revolta civil acionada pela legião de estarrecidos do planeta".

Boaventura de Sousa Santos $(1997 ; 2000)$ afirma que se atravessa um período de transição. Fazendo um balanço crítico do projeto da 
modernidade, afirma que a mesma que assenta-se em dois pilares fundamentais: o da "regulação" e o da "emancipação", sendo que o equilíbrio pretendido entre eles obtém-se através do desenvolvimento harmonioso de cada um dos pilares e das suas inter-relações dinâmicas.

À medida que a trajetória da modernidade identificou-se com a trajetória do capitalismo, houve o fortalecimento do pilar da regulação, "à custa do pilar da emancipação num processo histórico não linear e contraditório, com oscilações recorrentes entre um e outro, nos mais diversos campos da vida coletiva e sob diversas formas: entre cientificismo e utopismo, entre liberalismo e marxismo, entre modernismo e vanguarda, entre reforma e revolução, entre corporativismo e luta de classes, entre capitalismo e socialismo, entre fascismo e democracia participativa, entre doutrina social da Igreja e teologia da libertação" (op. cit. p.236).

A idéia de emancipação, enquanto promessa da Modernidade e herança do lluminismo, ainda não se efetivou à toda população configurando-se em uma das inquietações da atualidade. Entretanto, esta não é a única promessa não efetivada, tem-se também as promessas de democracia e da cidadania universal trazidas ao debate da atualidade como condições essenciais à constituição de uma outra sociedade, mais justa e igualitária.

Ao trabalhar com os conceitos de subjetividade, cidadania e emancipação, Santos (1997, p.240) ressalta a existência, na Modernidade, de uma tensão entre os mesmos. A cidadania refere-se muito mais a sociedade civil e política, sendo que o seu exercício reside quase exclusivamente no voto. A subjetividade, contudo, para além das idéias de

\footnotetext{
${ }^{4}$ Segundo Santos (1997) o pilar da regulação constitui-se pelos princípios do Estado, da Comunidade e do mercado, que devem estar articulados e organizados de tal forma que se auto-sustentem internamente. Entretanto, dentre estes, destacaram-se o Estado e o Mercado. O pilar da emancipação constitui-se da articulação entre três dimensões da racionalidade: racionalidade moral-prática do direito moderno, racionalidade cognitivo experimental da ciência e da técnica modernas, e pela racionalidade estético expressiva das artes e da literatura modernas; aqui também houve a superposição da ciência e da técnica a serviço da tecnologia e do capital.
} 
autonomia e liberdade envolve "as idéias de auto-reflexibilidade e de autoresponsabilidade, a materialidade de um corpo (...), e as particularidades potencialmente infinitas que conferem $\mathrm{o}$ cunho próprio e único à personalidade". Conclui-se, portanto, que a cidadania ao igualar as pessoas se choca com a alteridade da subjetividade sendo que a sua mediação se dá a nível da regulação, o que impossibilita a superação dessa tensão que apenas se dará no marco da emancipação.

O autor (1997, p.247) ressalta que os processos históricos da cidadania e da subjetividade são autônomos, ainda que intimamente relacionados, concluindo que, do ponto de vista da emancipação, é "possível pensar em novas formas de cidadania (colectivas e não individuais; menos assentes em direitos e deveres do que em formas e critérios de participação), não liberais e não-estatizantes, em que seja possível uma relação mais equilibrada com a subjectividade".

A crise da cidadania social deveu-se à crise do Estado- providência e revela, segundo Santos, em parte:

"a revolta da subjetividade contra a cidadania, da subjetividade pessoal e solidária contra a cidadania atomizante e estatizante. $\mathrm{O}$ compromisso social-democrático amarrou de tal modo os trabalhadores e a população em geral à obsessão e às rotinas da produção e do consumo que não deixou nenhum espaço para o exercício da autonomia e da criatividade (...) transformaram a solidariedade social numa prestação abstrata de serviços burocráticos benevolentemente repressivos (...) por último (...) acabou (...) por reduzir ainda mais o campo político. A representação democrática perdeu o contacto com os anseios e as necessidades da população representada e fez-se refém dos interesses corporativos poderosos" (op.cit., p.248-9). 
Diante desse quadro, a época contemporânea exige uma nova teoria democrática voltada a "reconstruir o conceito de cidadania, uma nova teoria da subjetividade (...) e uma nova teoria da emancipação" (op. cit. 270).

Para além do ato de votar é necessário o estabelecimento de critérios democráticos de participação, caso pretenda-se efetivamente promover a renovação da teoria democrática, o que implica na articulação entre democracia representativa e democracia participativa. Nesse sentido é urgente "que o campo político seja radicalmente redefinido e ampliado" (op. cit. p.271). Essa nova teoria democrática implica na transformação profunda do espaço da cidadania, no sentido de "eliminar os novos mecanismos de exclusão da cidadania, de combinar formas individuais com formas coletivas de cidadania e, finalmente, no sentido de ampliar esse conceito para além do princípio da reciprocidade e simetria entre direitos e deveres" (p.276).

Ações nesse sentido emergiram nos anos sessenta e oitenta, com a ação dos movimentos sociais e, posteriormente, dos "novos" movimentos sociais. Segundo Gohn (1995, p.44) movimentos sociais:

"são ações coletivas de caráter sociopolítico, construídas por atores sociais pertencentes a diferentes classes e camadas sociais. Eles politizam suas demandas e criam um campo político de força social na sociedade civil. Suas ações estruturam-se a partir de repertórios criados sobre temas e problemas em situações de: conflitos, litígios e disputas. As ações desenvolvem um processo social e político-cultural que cria uma identidade coletiva ao movimento, a partir de interesses em comum. Esta identidade decorre da força do princípio da solidariedade e é construída a partir da base referencial de valores culturais e políticos compartilhados pelo grupo".

Por outro lado os "novos" movimentos sociais compreendem aos movimentos das mulheres, ecológicos, pacifistas, étnicos, contra a fome, 
dentre outros, indicando um distanciamento do caráter classista predominante nos movimentos sindicais e operários em torno do mundo do trabalho e da produção. Reivindicam as demandas coletivas e também subjetivas das pessoas e têm revelado mais cabalmente a alteridade e as diversas especificidades que marcam a existência humana. Para SchererWarren (1996, p.49-50) os "novos" movimentos sociais:

"almejam atuar no sentido de estabelecer um novo equilíbrio de forças entre Estado (aqui entendido como o campo da política institucional: o governo, dos partidos e dos aparelhos burocráticos de dominação) e sociedade civil (campo da organização social que se realiza a partir das classes sociais ou de todas as outras espécies de agrupamentos sociais fora do Estado enquanto aparelho), bem como no interior da própria sociedade civil nas relações de força entre dominantes e dominados, entre subordinantes e subordinados".

Na visão de Santos (1997, p.261) a importância maior dos novos movimentos sociais deve-se à tentativa de procurar um novo equilíbrio entre cidadania e subjetividade. Nesse sentido, ampliaram-se o debate sobre as limitações da cidadania social e daquela circunscrita ao liberalismo que, a despeito da conquistas realizadas, estão longe de ser plenas e de atender às demandas da população. Por isso defendem e buscam uma "cidadania de nível superior capaz de compatibilizar o desenvolvimento pessoal com 0 coletivo e fazer da "sociedade civil uma sociedade política onde o Estado seja um autor privilegiado mas não único" (op. cit. , p.268).

O autor afirma (2001, p.344-5), ainda, que encontra-se em curso não uma transição, mas duas transições paradigmáticas autônomas, embora intimamente relacionadas. $\mathrm{E}$ a unir estas duas transições está o conceito de subjetividade, uma subjetividade emergente caracterizada, por um lado pela necessidade "de se conhecer a si mesma e ao mundo através do 
conhecimento-emancipação, recorrendo a uma retórica dialógica e a uma lógica emancipatória; por outro lado tem de ser capaz de conceber e desejar alternativas sociais assentes na transformação das relações de poder em relações de autoridade partilhada e na transformação das ordens jurídicas despóticas em ordens jurídicas democráticas".

Essa subjetividade deve ter o futuro como uma questão pessoal e o passado como uma "metonímia de tudo o que fomos e não fomos", ou seja, repleto de possibilidades não realizadas. Daí a necessidade de realizar a "arqueologia virtual do presente", buscando identificar o que não foi feito e refletir sobre o que impediu tal realização. Esta "escavação" deve possibilitar a exploração das possibilidades emancipatórias abertas pela subjetividade (Santos, 1997, 2001).

Nesse sentido, é preciso refletir com muito cuidado sobre os reais interesses da disseminação por todo o planeta de conclusões relacionadas ao fim da história e da utopia. Está claro que, na perspectiva da produção de subjetividades que sempre permeou o ideário capitalista, essa idéia é muito útil na configuração de uma humanidade apática, acomodada, individualista e submissa.

Perante a crise das velhas utopias e as imensas nuvens de incerteza que se deparam ao mundo contemporâneo, os desafios futuros e a recriação de novas utopias exigem, pois, uma permanente reinvenção do passado como resposta ao risco de eternização do presente que as subjetividades fragmentárias e simplificadas acarretam.

Dessa forma, assiste-se em diferentes locais do planeta, ao surgimento de "projetos utópicos, disparados por desejos de transformação mobilizados por energias utópicas" (Tassara, 1997, p. 43). Exemplos como os do Fórum Social Mundial, já em sua terceira edição, demonstram a pertinência da retomada da idéia de utopia e de projeto. A partir do que existe, do que existiu e, acima de tudo, do que pode existir, trabalhar na 
construção de um outro mundo, que abra possibilidades reais à liberdade, à solidariedade e à felicidade. Nesse sentido Santos afirma que

"A utopia é (...) o realismo desesperado de uma espera que se permite lutar pelo conteúdo da espera, não em geral, mas no exacto lugar e tempo em que se encontra. A esperança não reside, pois, num princípio geral que providencia por um futuro geral. Reside antes na possibilidade de criar campos de experimentação social onde seja possível resistir localmente às evidências da inevitabilidade, promovendo com êxito alternativas que parecem utópicas em todos os tempos e lugares excepto naqueles em que ocorrem efetivamente. É este o realismo utópico que preside às iniciativas dos grupos oprimidos que, num mundo onde parece ter desaparecido a alternativa, vão construindo, um pouco por toda a parte, alternativas locais que tornam possível uma vida digna e decente."

Tal afirmação chama a atenção para a necessidade de exploração, através da imaginação, de novas possibilidades humanas e novas formas de vontade indicando que existe algo radicalmente melhor pelo que vale a pena lutar e ao qual a humanidade tem direito. Dessa forma, a reinvenção do futuro através do estabelecimento de uma cultura emancipatória passa pela criação de espaços voltados ao empoderamento dos sujeitos e dos coletivos visando uma atuação que promova a melhoria da qualidade de vida e do meio ambiente. 


\subsubsection{Sobre a subjetividade}

"Na medida em que se faz subjetividade, o ser humano pode questionar-se $e$ considerar-se como origem, certamente parcial, da sua história passada, como também querer uma história que está por vir e querer ser seu co-autor".

Cornelius Castoriadis

Sawaia (2001) ressalta que ao relacionar a questão da subjetividade e a consolidação de processos emancipatórios é importante observar os dois perigos dessa mediação analítica. Um relaciona-se ao que a autora denomina "caráter fashion" da subjetividade, ou seja, a pressão resultante do consenso instalado na modernidade contemporânea fazendo com que o conceito seja incorporado por diversos setores e amplamente difundido na mídia, o que ocasiona sérias distorções conceituais. O outro perigo refere-se à lógica que impera na sociedade atual, que tudo subordina aos interesses eminentemente econômicos, ou seja, ao que determina o mercado e o capital. Nesse sentido, o uso do conceito da subjetividade ao invés de relacionar-se à recuperação da dimensão humana, esquecida na Modernidade, pode promover a manipulação e exploração dos indivíduos em benefício do lucro.

Nesse sentido Guattari $(1999$, p.26) ressalta que, enquanto os marxistas e os progressistas não entenderam a questão da subjetividade, isso "não aconteceu com as forças sociais que administram o capitalismo hoje. Elas entenderam que a produção da subjetividade talvez seja mais importante do que qualquer outro tipo de produção, mais essencial que o petróleo e as energias". Essa produção da subjetividade objetiva, no presente caso, o controle da sociedade. E conclui afirmando que: 
"Tais mutações da subjetividade não funcionam apenas no registro das ideologias, mas no próprio coração dos indivíduos, em sua maneira de perceber o mundo, de se articular como tecido urbano, com os processos maquínicos do trabalho, com a ordem social suporte dessas forças produtivas. E se isso é verdade, não é utópico considerar que uma revolução, uma mudança social a nível macropolítico, macrossocial, diz respeito também à questão da produção da subjetividade, o que deverá ser levado em conta pelos movimentos de emancipação" (op.cit, p.26).

Castoriadis (1992) caracteriza a subjetividade humana a partir de duas possibilidades: a reflexividade e a vontade ou capacidade de atividade deliberada. Segundo o autor na reflexividade tem-se "a possibilidade de que a própria atividade do "sujeito" torne-se "objeto", a explicitação de si como um objeto não-objetivo", ou como "objeto simplesmente por posição e não por natureza". E na medida em que alguém pode ser para si mesmo um objeto por posição e não por natureza é que "outrem", no verdadeiro sentido do termo torna-se possível.(...) A reflexão implica a possibilidade da "cisão" e da "oposição interna", portanto, também a possibilidade do "questionamento" de si mesmo". O autor aponta que a condição de possibilidade absoluta da reflexividade é a imaginação.

A vontade ou capacidade deliberada é entendida como a possibilidade de um ser humano integrar nas retransmissões que condicionam os seus atos os resultados de seu processo de reflexão. Ou seja, é a "dimensão refletida do que nós somos enquanto seres imaginários, a saber criativos, ou ainda: a dimensão refletida e prática da nossa imaginação como fonte de criação". Nesse sentido há uma relação profunda entre a imaginação e a vontade na medida que "é necessário poder imaginar outra coisa fora daquilo 
que é para poder querer; e é necessário querer outra coisa fora daquilo que é para liberar a imaginação" (Castoriadis, 1992, p.260).

Entende-se que a sociedade contemporânea ao negar e destruir a vida da imaginação e ao não compreender a subjetividade, caminha rapidamente no sentido da inexpressividade, da paralisia e da neutralidade e, o que é mais grave, da coisificação do homem e da sua existência.

É necessário, pois, recolocar no cenário social o humano enquanto humano, enquanto valor, muito além do individualismo egoístico e narcísistico que marca a modernidade, revalorizando sentimentos, afetos e desejos. Sawaia (2000) considera que "a afetividade (emoção e sentimentos) é um universo particular de estudo e de ação social transformadora que supera a cisão universal/particular e mente e corpo. Ela é a dimensão particular de uma ação política: encontrar um meio de entrar no que há de mais singular da vida social e coletiva, em sua singularidade, para promover a transformação social".

Com relação à conscientização política a autora afirma que abrir mão da dimensão ético-estética ${ }^{5}$ é cair na práxis reducionista. Ressalta, também, o que considera ser a principal lição dos movimentos sociais no final do século XX: a importância da dimensão subjetiva e intersubjetiva da participação social. Participação e subjetividade são indissociáveis, mas não reduzem-se umas às outras.

Por fim, afirma que:

"As ciências do homem podem colaborar com esse processo, promovendo a revisão crítica das teorias da subjetividade, no sentido de superar a dicotomia entre subjetividade individual e coletiva, entre subjetividade contextualizada e universal, bem como superar a concepção de subjetividade como fonte de erro e parcialidade ou de subjetividade asséptica, expurgada dos vícios da carne ou ainda da 
subjetividade como mônada consciente que conhece e interpreta o mundo" (Sawaia, 1998, p. 100).

Considera fundamental recorrer a autores como Espinosa, Schiller, Fourier e Heller, para aprender com eles e recuperar a afetividade e as emoções como dimensão fundamental do comportamento político. Seguindo essa recomendação realizou-se um estudo sobre a obra de Espinosa, fundamental para o planejamento de programas educativos que visem à transformação social. Sawaia (1998, p.121) defende que:

"a qualidade emancipadora da idéia de sujeito traduz-se: 1) Enquanto epistemologia, na recusa ao fechamento de horizontes, de expectativas e de possibilidades, unindo ação e pensamento e sujeito e objeto; 2) enquanto psicologia, na recusa à subjetividade do conformismo, da determinação e na criação da vontade de lutar e 3) enquanto ação política, na união entre o individual e o coletivo e entre o público e o privado".

\subsection{Potência de Ação - uma leitura preliminar da filosofia de Espinosa}

Merleau-Ponty citado por Marilena Chauí (1995, p. 81) diz que um clássico é aquele que sempre terá alguma coisa a nos dizer porque, ao pensar, nos deu o que pensar e que no modo como enfrenta as questões de seu tempo e a elas oferece respostas, ensina-nos a interrogar nosso próprio tempo. Chauí (op. cit.) complementa afirmando:

\footnotetext{
${ }^{5}$ Vide nota anterior, referente aos pilares da emancipação e da regulação (Santos, B., 1997)
} 
"Uma obra de pensamento é grande quando é fecunda. É fecunda quando nos faz pensar para além dela, e graças a ela. E nos dá a pensar porque cria, por sua própria força, um campo de pensamento no qual aprendemos a ouvir uma interrogação que abre caminho para a nossa. Quanto mais imerso em seu tempo, mais o verdadeiro pensador se abre para o tempo futuro".

Acredita-se ser oportuno transcrever, aqui, o texto com que Deleuze inicia a sua obra Espinoza e os Signos:

" - Diga-me o que o levou a ler Espinoza? (...)

Encontrei o volume em casa de um antiquário na cidade vizinha; paguei-Ihe um kopeck, arrependendo-me imediatamente de gastar esse dinheiro que tanto me custou a ganhar. Mais tarde li umas páginas, e depois continuei como se uma rajada de vento me impelisse. Digo-lhe que não compreendi tudo, mas desde que alguém toma contato com idéias semelhantes, é como se montasse uma vassoura de bruxa. Deixei de ser o mesmo homem...

- Quer explicar-me qual o significado que tem para você a obra de Espinoza? Por outras palavras, se é uma filosofia, em que consiste ela?

- Não é fácil dizê-lo. Conforme o assunto tratado em diversos capítulos, e ainda que tudo se sustente subterraneamente, o livro significa diferentes coisas. Mas eu creio que ele significa sobretudo que Espinoza quis fazer de si mesmo um homem livre - tão livre quanto é possível, de acordo com a sua filosofia, se compreende o que quero dizer - indo até ao limite dos seus pensamentos, e unindo todos os elementos uns aos outros.

Não é um mau modo de abordar o problema. Mais através do homem, que através da sua obra. Mas..." 
É a partir de uma perspectiva de busca de respostas e ou outras questões, que pretendo apresentar a obra de Espinosa e as suas possíveis conexões com um processo educacional que voltado à emancipação.

Para o entendimento adequado de Espinosa e, consequentemente, de sua obra seria necessário a contextualização do momento histórico que ele viveu, suas preocupações, seus interlocutores, ou seja, seria necessário a explicitação da rede complexa de relações que resultaram na sua produção. Porém, tamanho desafio confronta-se com a limitação de tempo para a realização dessa pesquisa, o que inviabiliza o aprofundamento teórico necessário ao entendimento de sua obra. Portanto, busca-se apresentar, de forma preliminar, aspectos que são relevantes e ou indispensáveis para a compreensão do conceito de potência de ação e suas múltiplas relações com uma proposta de educação ambiental emancipadora.

Cabral Pinto (1990, p.12) ressalta que a obra de Espinosa:

"não é compatível com nenhum regime que faça diminuir, em proveito exclusivo de alguns, a potência de agir e compreender de outros; por outras palavras, não é compatível com nenhum regime que faça da ignorância e da superstição instrumentos da exploração do homem pelo homem".

Essa compreensão é possível quando tem-se claro o foco central da sua obra, ou seja, a servidão humana em todas as suas formas e os caminhos pelos quais a verdadeira liberdade pudesse tornar-se desejada e acessível a todos os seres humanos.

Sua obra, especialmente a Ética, é fundamentalmente política e possui como grande objetivo revelar o que é a liberdade humana, considerada por ele a maior de todas as necessidades do homem. Andrade (1997, p.8) considera ser a tese central da sua obra a afirmação de que a 
liberdade nada mais é do que o domínio racional do sujeito sobre si mesmo. Nesse sentido, a Ética se volta para o entendimento da relação entre a razão e os afetos na mente humana.

Espinosa demonstra que para o ser humano a maior virtude a ser alcançada é apreender-se como um ser que toma parte ativa na Natureza, isto é, como um ser que é simultaneamente capaz de conhecer sua essência singular envolvida pela ordem inteira da Natureza, e que persevera no esforço de tornar-se a cada dia mais apto a viver singularmente esse envolvimento com ela, exprimindo-a de um modo singular, certo e determinado, no interior de um sistema de forças produzidas por outras essências singulares que a afetam e são afetadas por ela - essa é a própria essência do homem livre (Balila, 2000).

Espinosa defende que corpo e alma estão sob as mesmas leis e sob os mesmos princípios, expressos diferenciadamente, rompendo-se a idéia de supremacia da alma (pura e divina) sobre o corpo (impuro e pecador). Sendo implacável quanto à questão da vontade livre. Para ele, o que é vontade na alma, é vontade no corpo; e o que é desejo no corpo, desejo na alma.

Para Espinosa o ser humano não nasce livre: torna-se livre. E a razão do engano, quanto a idéia de ser naturalmente livre, vem da consciência. Esta, que apenas sofre os efeitos dos encontros, ou seja, alegria quando realiza um bom encontro e tristeza, ao se deparar com um corpo que enfraquece sua potência, é desconhecedora das causas e, por isso, toma efeitos por causas. Além disso, há uma tendência do homem a considerar-se causa primeira dos seus atos, invocando assim o poder sobre seu corpo (estaria aqui a ilusão dos decretos livres ou livre-arbítrio). Por essas e por outras razões, Espinosa considera que o homem desconhece não só o que 
pode seu corpo, mas também toda a problemática das relações existenciais. Observe o que diz o escólio à Proposição 35, do Livro II , da Ética ${ }^{6}$ :

“(...) os homens enganam-se quando se julgam livres; e esta opinião consiste apenas em que eles têm consciência das suas ações e são ignorantes das causas pelas quais são determinados. O que consistiu, portanto, a idéia da sua liberdade é que eles não conhecem nenhuma causa das suas ações. Com efeito, quando dizem que as ações humanas dependem da vontade, dizem meras palavras das quais não têm nenhuma idéia".

Portanto, as opções que o ser humano faz não são livres: são determinados pelo nível dos seus conhecimentos. Se o conhecimento for inadequado (submetido aos mitos e à ilusão), as opções serão feitas no sentido de bens instáveis (o homem estará sujeito às flutuações da alma); se, ao contrário disso, o conhecimento é adequado, os bens serão duradouros (o homem descobrirá o proprium uitile) (Cabral Pinto, 1990, p. 12-3).

Isso deve-se ao fato dos homens preocuparem-se mais em deplorar as paixões (consideradas vícios da vontade) do que em compreendê-las e explicá-las. Segue daí que nada que se passa com os homens, ou com qualquer outra criatura, pode ser desqualificado ou deixado de lado. Há que se entender que as paixões resultam de leis necessárias da própria natureza divina.

A filosofia espinosana considera que para ser feliz é necessário seguir o caminho da razão, compreendida não como negação dos afetos, mas como um produto deles próprios. A natureza humana não é exclusivamente

\footnotetext{
${ }^{6}$ Forma de citação: nome da obra abreviado, em romano a parte, em arábico definições, axiomas, postulados, lemas, proposições, corolários e escólios antecedidos da letra correspondente. Exemplo EII P7 D - Ética, parte II, proposição 7, demonstração.
} 
racional, nem é primordialmente racional: o homem é fundamentalmente um ser passional, um ser afetivo, que tanto pode ser levado pelas paixões (o que significa ser o seu servo), quanto pode agir por meio delas (o que significa ser racional). O que move o sujeito não é a razão, mas sim o desejo; a razão é apenas um instrumento para a realização do que se deseja (Andrade, 1997, p. 9).

A desvantagem em tornar-se servo das paixões não está em cometer uma imoralidade, visto que a imoralidade não existe; está, sim, em destruirse a si próprio. A autodestruição é uma contradição da natureza humana.

"Toda coisa se esforça, enquanto está em si, por perseverar no seu ser" (EIII, PVI).

Esta potência de autopreservação é o conatus, presente em todos os seres. E é tão essencial a todas as coisas do real que, no caso do ser humano, dotado de consciência e vontade, é impossível desejar não ter essa capacidade de autopreservação (Andrade, 1997; Chauí, 1983).

É importante que se faça, nesse momento, uma breve descrição da teoria dos afetos. Os afetos podem ser compreendidos como fenômenos mentais que possuem uma causa bem determinada, cujo grau de inteligibilidade é a condição para a diferenciação da ação e da paixão. A causa divide-se em adequada e inadequada; sendo a causa adequada condição para a determinação de um movimento mental enquanto ação e a inadequada condição para a determinação de um movimento mental enquanto paixão.

Para Espinosa nossa alma age - é ativa - quanto a certas coisas, e sofre - é passiva - quanto a outras. Todos os corpos se relacionam, e isto porque todo corpo tem o poder de afetar e de ser afetado. Segundo Espinosa existem dois tipos de afeç̧ões: as paixões e as ações. Sou um ser apaixonado quando algo que está fora produz, em mim, um afeto, ou seja, 
quando a causa de um afeto meu é exterior a minha "natureza". Ao contrário disso, ajo quando sou a causa de algo exterior a mim.

Segue-se daí que, no decorrer de nossa existência, nosso ${ }^{7}$ corpo sofre numerosas transformações. Nossa alma age ou, de outra maneira, nosso corpo aumenta sua potência de agir, quando somos a causa adequada de algo que se produz em nós ou fora de nós. Causa adequada é aquela cujo efeito pode ser clara e distintamente compreendido por ela, não havendo nada fora dela que a explique. Nossa alma, então, age enquanto tem em si idéias adequadas, e sofre enquanto tem idéias inadequadas. Daí se segue que a alma está sujeita a um número de paixões tanto maior, quanto maior é o número de idéias inadequadas que tem; e, ao contrário, é tanto mais ativa quanto mais idéias adequadas tem.

A essência singular humana é conhecimento, ou seja, buscamos estabelecer relações entre as coisas, ao mesmo tempo em que vamos construindo teorias interpretativas sobre os nossos comportamentos e sobre o mundo em que vivemos.

Não é possível ao ser humano viver sem relacionar-se. E dessas relações tem-se que distinguir duas possibilidades: ou o ser humano encontra outros seres que convenham consigo e compõem a sua relação com a sua, como por exemplo, um alimento, um ser amado, um aliado; ou então encontra-se com outros seres que com que ele não convêm e tendem a decompô-lo, a destruí-lo como, por exemplo, um veneno, um inimigo, um ser odiado. No primeiro, somos afetados por afetos-sentimentos alegres, à base de gozo e amor; no outro caso, pelos afetos-sentimentos tristes, à base de tristeza e ódio. O processo de aprendizagem do homem caminha no sentido de buscar atrair as coisas que Ihe dão prazer, isto é, aumentam sua força ou potência de existir e agir, e de afastar-se das coisas e ou relações

\footnotetext{
${ }^{72}$ Nesse item uso o verbo na terceira pessoa do plural, por considerar mais adequado à explicação da obra de Espinosa.
} 
que Ihe causem sofrimento, consequentemente, diminuindo sua potência de agir (Deleuze, s/d).

Esses sentimentos, de prazer e sofrimento, de alegria e tristeza, suprem, embora com menos eficácia, a falta de um conhecimento adequado do bem e do mal verdadeiros, isto é, do que na realidade seria verdadeiramente útil - proprium utile - ou prejudicial a cada ser humano tendo em vista a sua conservação. Eles servem de guia na ausência da razão.

Em sua teoria do conhecimento Espinosa distingue três gêneros de conhecimento: o conhecimento imaginativo, o conhecimento racional e o conhecimento intuitivo.

"Na passividade produzimos idéias imaginativas das coisas que nos fazem conhecer os objetos exteriores segundo a maneira pela qual afetam o nosso corpo, nesse caso, desconhecemos a essência dos mesmos e passamos a conceber a realidade a partir das impressões deixadas por eles em nós, ou seja, formamos um conhecimento da realidade e formulamos interpretações sobre a mesma à partir dos efeitos provocados pelas coisas exteriores em nosso corpo, desconhecendo então tanto a essência dessas coisas quanto a essência de nosso próprio corpo" (Balila, 2000).

Enfim, o que se conhece dessa forma não é senão a modificação que se produz no nosso corpo por ação de outros corpos, uma vez que este conhecimento - situado ao nível do primeiro conhecimento - diz respeito à imaginação que os sentimentos representam de forma mutilada, confusa e sem ordem ao entendimento.

$\mathrm{O}$ conhecimento racional diz respeito às idéias adequadas. É quando nos tornamos plenamente ativos, uma vez que conhecemos por nós mesmos as causas e efeitos das idéias, a gênese necessária delas, os nexos que 
formam com outras em conexões e ordens internas e necessárias; ou seja, na razão as idéias adequadas nos fornecem sistemas de relação - leis de realidade (Chauí, 1996, p. 39).

Daí surge uma questão essencial para o entendimento da filosofia espinosana: Como se formam as idéias adequadas? Como passamos do conhecimento imaginativo para o conhecimento racional?

Nesse momento Espinosa introduz a idéia de noção comum que, segundo Deleuze (s/d, p. 109-111), é a representação de uma composição entre dois ou vários corpos, e de uma unidade dessa composição, ou seja, exprime as relações de conveniência ou de composição dos corpos existentes. As noções comuns, ao representarem uma unidade de composição, tanto estão na parte como no todo e não podem ser concebidas senão adequadamente, conforme as Proposições XXXVIII e XXXIX, do livro II, da Ética, respectivamente:

"As coisas que são comuns a todas as coisas e existem igualmente no todo e nas partes não podem ser concebidas senão adequadamente".

"Aquilo que é comum e próprio ao corpo humano e a certos corpos exteriores, pelos quais o corpo humano é habitualmente afetado, e é comum e próprio a cada uma das suas partes assim como ao todo, a sua idéia existirá adequada na alma".

Quando encontramos um corpo que convém com o nosso, experimentamos um afeto ou sentimento de alegria-paixão, mesmo que ainda não conheçamos o que ele tem de comum conosco. Jamais a tristeza, que nasce do nosso encontro com um corpo que não convém com o nosso, nos induzirá a formação de uma noção comum; mas a alegria-paixão, enquanto aumento da potência de agir e de compreender, induz-nos a fazêlo, ou seja, é causa ocasional da noção comum. 
Tal situação confirma que o homem não nasce racional, mas torna-se racional. Segundo Deleuze (s/d, p.40), de duas maneiras se define a razão:

" $1^{\circ}$ - um esforço para selecionar e organizar os bons encontros, isto é, os encontros dos modos que se compõem conosco e nos inspiram paixões alegres (sentimentos que convêm a razão);

$2^{\circ}$ - a percepção e compreensão das noções comuns, isto é, das relações que entram nesta composição, de onde se deduzem outras relações (raciocínio) e a partir das quais se experimentam novos sentimentos, desta vez activos (sentimentos que nascem da razão)".

Ou seja, o que desejamos é sempre uma coisa útil à conservação do nosso ser, algo que faz aumentar a nossa potência de agir.

Em seguida tem-se o terceiro gênero de conhecimento: a ciência intuitiva, que nos permite apreender a essência íntima da relação entre as partes e o todo. A ciência intuitiva oferece-nos o conhecimento de essências singulares, isto é, a natureza e a realidade íntimas e verdadeiras de alguma coisa (Chauí, 1995, p. 39).

Faz-se necessário, nesse momento, que retomemos a discussão sobre o conatus, para o entendimento do que é potência de agir. O conatus pode dizer respeito ao corpo apenas, à mente apenas, ou à mente e o corpo juntos, sendo tal distinção importante porque a partir dela Espinosa diferencia de maneira explícita a vontade e o apetite, como esclarece o escólio à Proposição IX, da Ética:

"Este esforço, enquanto se refere apenas à alma, chama-se vontade; mas quando se refere ao mesmo tempo à alma e ao corpo, chama-se apetite. $O$ apetite não é senão a própria essência do homem, da natureza da qual se segue necessariamente o que serve para a sua 
conservação; e o homem e, assim, determinado a fazer essas coisas. Além disso, entre o apetite e o desejo não há nenhuma diferença, a não ser que o desejo se aplica geralmente aos homens quando têm consciência do seu apetite e, por conseguinte, pode ser assim definido: o desejo é o apetite de que se tem consciência. É, portanto, evidente, em virtude de todas estas coisas, que nos não esforçamos por fazer uma coisa que não queremos, não apetecemos nem desejamos qualquer coisa porque a consideramos boa; mas, ao contrário, julgamos que uma coisa é boa porque tendemos para ela, porque a queremos, a apetecemos a desejamos" .

Em síntese,

"dizer que somos apetite corporal e desejo psíquico é dizer que as as afecções do corpo são afetos da alma. Em outras palavras, as afecções do corpo são imagens que, na alma, se realizam como idéias afetivas ou sentimentos. Assim, a relação originária da alma com o corpo e de ambos com o mundo é a relação afetiva" (Chaui, 1995, p. 64).

Do exposto até aqui compreende-se que ação é a postura ética positiva e a paixão a postura negativa de forma que a primeira, enquanto atividade favorece e a outra, enquanto passividade, prejudica a realidade física do sujeito, ou seja, a potência de existir e agir. A condição para a atividade do sujeito é a consciência racional e precisa que ele tem de si mesmo enquanto causa para os efeitos que se produzem no real. $O$ sujeito só pode ser ativo com relação aos efeitos de que ele próprio reconhecer ser a causa; com relação aos demais fenômenos do real dos quais ele também é a causa, mas não detém uma compreensão precisa da maneira como o é, a postura do sujeito é necessariamente passiva, e sua causalidade meramente 
parcial, tanto que a compreensão que ele pode ter de tais fenômenos não tem como não ser equívoca.

A potência é a própria essência dos seres, é o seu poder de ação, daí que as relações existenciais devem ser pensadas em termos de composições e decomposições: quando um corpo se compõe ao outro, aumenta o seu poder de ação. Mas nem todos os corpos e idéias se compõem: a morte, por exemplo, é o resultado de um mau encontro de corpos. A causa da morte de um corpo nunca pode estar no próprio corpo, sendo sempre algo exterior a ele; daí porque a morte é também considerada um efeito das relações existenciais. Uma idéia que exclui a existência do nosso corpo não pode existir na nossa alma, mas é-lhe contrária. Disto conclui-se que: 1) o que pode destruir nosso corpo não pode existir nele, nem em Deus, enquanto ele tem a idéia do nosso corpo; 2) nem todos os encontros de corpos são bons para a natureza dos mesmos.

"O homem livre em nada pensa menos que na morte; e a sua sabedoria não é uma meditação da morte, mas da vida" (EV, PLXVII).

"A virtude de um homem livre revela-se tão grande quando evita como quando supera os perigos" (EV, PLXIX).

Daí, o bom encontro estar associado a um aumento de nossa potência, e a liberdade ser pensada como a força de provocar tais encontros e não viver ao acaso deles. Como essência singular, como um grau de potência, o homem deve, dentro de seus próprios limites, procurar provocar encontros que aumentem ao máximo sua potência de agir.

Segundo Espinosa, todos os apetites e desejos humanos são variantes da combinação de três afetos imaginários: o desejo, a alegria e a tristeza, sendo que a tristeza resulta de nossa incapacidade para vencer obstáculos que se interpõem a nossa existência, expressão e realização 
plenas; a alegria é uma paixão positiva, que conduz o homem à superação de sua passividade por sua tendência ao conhecimento claro e distinto daquilo que aumenta o seu conatus. Alegria e tristeza estão posicionados nos domínios extremos da vida passional, como formas de manifestação da intensidade da atividade de nosso conatus quando o nosso desejo está direcionado a coisas externas (Balila, 2000).

Pode-se dizer que o rancor, o ressentimento e a inveja são resultados diretos das paixões tristes. São eles que envenenam a nossa alma, destruindo nosso poder de agir e enfraquecendo a nossa vida. São os nossos valores que regem a nossa existência e não a nossa vontade. Se não compreendermos isso, jamais nos tornarmos senhores de nós mesmos. $O$ conhecimento, aliado aos bons encontros, é o que torna o homem livre.

$\mathrm{Na}$ filosofia de Espinosa a relação entre a dimensão subjetiva da potência de ação e a dimensão política é evidente, como veremos. Sempre enfatizando o esforço que o homem faz para conservar sua existência conatus - o filósofo traça, em linhas gerais, o que pressupõe como uma sociedade que funcione de maneira adequada. Na política, entretanto, o conatus chama-se direito natural.

A sociedade política - o coletivo dos seres regidos por normas previamente estabelecidas - existe como efeito desse esforço humano para conservar-se, como vemos abaixo:

"Se duas pessoas concordam entre si e unem as suas forças, terão mais poder conjuntamente e, consequentemente, um direito superior (...) que cada uma delas não possui sozinha e, quanto mais numerosos forem os homens que tenham posto as suas forças em comum, mais direito terão eles todos" (TP cap. II, 13) ${ }^{8}$.

\footnotetext{
${ }^{8}$ Tratado Político, capítulo II, 13.
} 
"Como, aliás, todos os homens temem a solidão, porque nenhum deles na solidão tem força para se defender e obter as coisas necessárias à vida" (TP, VI, 1).

"Aos homens é-lhes útil, primeiro que tudo, estreitar as relações e unirem-se pelos vínculos que melhor podem fazer deles todos uma só coisa, e, de uma maneira geral, é-lhes útil fazer aquilo que serve para consolidar as amizades " (EIV PLXXIII, cap. XII).

Pode-se afirmar que a convivência nessa sociedade política pressupõe a existência de um pacto firmado entre os seus membros através do qual, cada um compromete-se a orientar os seus atos sociais pelos princípios comuns e a refrear as paixões de tendência oposta aos interesses da vida comunitária. Nessa perspectiva, as decisões sobre os interesses da coletividade deveriam ser tomados em assembléias com a participação de todos os seus membros ou daqueles eleitos democraticamente.

Essa sociedade pauta-se na igualdade sem reservas entre os cidadãos, uma vez que ninguém transfere os seus direitos para um outro indivíduo, de tal modo que jamais tivesse de ser consultado em matéria de governo, mas para a totalidade da sociedade de que faz parte (Cabral Pinto, 1990, p. 101-2).

E mesmo o soberano ou o Governo, também eleito pelos cidadãos, deve observar tais postulados, uma vez que sua função restringe-se à execução do que foi deliberado em assembléia, devendo buscar a promoção da segurança indispensável para que cada um possa explorar como the aprouver, as faculdades do seu corpo e da sua alma. Não cabe tentar transformar os cidadãos em seres sem reflexão crítica ou vontade própria, próprios da servidão.

Nesse sentido, os homens determinados a agir pela força das idéias adequadas e não das inadequadas, preferem sofrer a perseguição dos 
tiranos a suportar uma tirania que resultará na redução da sua potência de agir. No Tratado Teológico Político, Espinosa afirma que os primeiros à resistir à tirania não são os bajuladores, os ambiciosos e ou outros indivíduos sem escrúpulos, para quem a salvação suprema consiste em contemplar as moedas de ouro da sua bolsa e em ter bem cheia a barriga, mas aqueles a quem a cultura, a pureza dos costumes e a virtude deram um pouco de liberdade.

Eis porque as primeiras ações dos tiranos - de ontem e de hoje - vão sempre no caminho de impedir a liberdade de opinião e o desenvolvimento das ciências e das artes.

Nisto reside a atualidade do pensamento de Espinosa: perceber que a associação dos homens em grupos - cooperativas, associações, municípios, etc - potencializa o seu direito natural de existir, já que nos unimos para suplantar o medo, o ódio e todas as coisas e ou sentimentos que possam nos trazer sofrimentos e reduzir-nos ao estado de servidão. É e nessa busca de liberdade e felicidade que, com base na experiência e na razão, viabilizamos diferentes formas de organização da vida coletiva, rejeitando umas, preferindo outras; mas sempre exercendo o nosso direito de escolher.

As lutas sociais são necessárias quando instala-se na sociedade uma situação inadequada - a dominação de uns sobre os outros - que entrava a nossa força de existir ou a nossa potência de ação, resultando que "o temor experimentado em comum pela maioria dos cidadãos se transforme em indignação" (TP, cap. III, 6).

Vale a pena refletir sobre o que Espinosa escreve a esse respeito no Tratado Político, capítulo 3, 6 :

"É preciso notá-lo ainda, o Estado que refiro como instituído com o fim de fazer reinar a concórdia deve ser entendido como instituído por uma população livre, e não como estabelecido por direito de conquista sobre uma população vencida. Sobre uma população livre a 
esperança exerce maior influência que o medo; sobre uma população submetida pela força, pelo contrário, é o medo o grande móbil, não a esperança. Da primeira pode-se dizer que tem o culto da vida, da Segunda que procura apenas escapar à morte; uma, digo que se esforça por viver por si mesma, a outra obedece constrangida à lei do vencedor".

Então, como passar da paixão à ação? Ou, como nos tornarmos causa adequada, isto é, causa total dos efeitos daquilo que se passa em nós, ou seja, como nos libertamos?

A princípio, diria que é perdendo o medo de viver em ato, como fala Marilena Chauí (1995). Mas a questão continuaria. Então, proponho refletirmos sobre essas possibilidades:

- Denunciar tudo o que nos separa da vida, todos os valores transcendentes que se orientam contra a vida unidos às condições e as ilusões da nossa consciência.

- Produzir alegrias, produzir encontros alegres. Transformar os encontros casuais, inadequados e predominantemente tristes dos corpos sociais e torná-los encontros coerentes, adequados e alegres.

- Entender que a participação nos diferentes espaços, públicos e privados, nos fortalecem enquanto sujeitos na luta contra a servidão e todas as formas de dominação.

Essas e outras possibilidades que apresentam-se a partir da reflexão sobre a obra de Espinosa demonstram a pertinência de aliar-se suas idéias ao planejamento e implementação de programas de Educação Ambiental voltados à formação de sujeitos críticos, criativos e autonômos. 


\subsection{Educação Ambiental para Sociedades Sustentáveis}

Ao longo dos últimos anos, especialmente na última década tem-se observado o crescente aumento das ações e publicações no campo da Educação Ambiental (EA), expressando uma diversidade de olhares e fazeres. À primeira vista pode até parecer que compartilham os mesmos valores, objetivos, interesses e ideário. Contudo, ao observar-se com mais atenção, percebe-se que escondem posturas políticas e visões de mundo bastante diversas, podendo possibilitar tanto a emergência de práticas educativas emancipatórias quanto privatizantes, que "remetem os indivíduos para "dentro de si" e para fora da história e da política" (Carvalho, 1998, p. 272).

Nesse sentido é relevante situar historicamente o seu surgimento e explicitar as principais tendências que compõem o campo da EA brasileira na atualidade .

Carvalho (1997, p.277-9) considera que a EA brasileira incrementa-se a partir do surgimento dos novos movimentos sociais e ONGs ambientalistas na década de 80. A autora afirma que "é principalmente no contexto de uma política afirmativa das novas temáticas culturais e atores sociais que mais e mais educadores incorporam um ideário ecológico em sua prática educativa e passam a chamar-se educadores ambientais".

Lima (2002, p. 121-2) entende que o processo de institucionalização da questão ambiental e, consequentemente, da EA se deu em duas principais direções: i) a primeira, pela expansão da informação, da problematização e da consciência ambiental, sendo que apesar da superficialidade e parcialidade das informações, a causa ambiental penetrou novos setores sociais e ganhou status de tema prioritário na agenda políticoeconômica contemporânea; ii) a outra funcionou na diluição dos conteúdos críticos do ambientalismo original e na substituição da perspectiva do conflito por uma perspectiva conciliatória. 
Como dito anteriormente, o campo da EA é marcado pela pluralidade e diversidade de ações, atores, porém esse estudo concentrar-se-a na tarefa de apresentar uma análise preliminar das principais matrizes políticopedagógicas que orientam o universo da EA. Para tanto baseia-se nos critérios diferenciadores dessas matrizes apontados por Lima (2002: 125-7) quais sejam:

a) A perspectiva de mudança social para indicar o potencial de conservação ou transformação de cada uma das matrizes;

b) O grau de integração para sinalizar o nível de complexidade ou de reducionismo na abordagem da questão e da educação ambiental;

c) O compromisso social, que mostrará a orientação comunitária/individualista das principais matrizes políticopedagógicas que orientam, em maior ou menor intensidade, todas as propostas teórico/práticas de EA.

Lima (Op.cit., 125-7) identifica as propostas teórico-práticas de EA polarizadas entre duas grandes concepções político-culturais que estruturam o debate da sustentabilidade, as quais chama de "conservadora e emancipatória". A primeira interessa-se pela manutenção da atual estrutura social, com as suas características e valores econômicos, políticos, éticos e culturais. Por outro lado, a emancipatória define-se no compromisso de transformação da ordem social vigente, de renovação plural da sociedade e de sua relação com o meio ambiente. $O$ autor propõe uma terceira categoria, como variante da conservadora, denominada "conservadorismo dinâmico", caracterizada por um perfil reformista, superficial e reducionista, já que opera "por mudanças aparentes e parciais nas relações entre a sociedade e o ambiente enquanto conserva o essencial" .

O autor entende que dentre os obstáculos para uma abordagem transformadora dos problemas ambientais está o conservadorismo dinâmico por: 
"representar o discurso hegemônico no campo ambiental, avalizado por um grande número de organismos governamentais, não governamentais e privados, nacionais e internacionais é, sem sombra de dúvida, o mais visível e freqüente nos meios de comunicação e, portanto, o mais acessível à maioria do público leigo. Em segundo lugar, por utilizar uma linguagem científica e técnica e transmitir uma imagem de neutralidade desses saberes, convertendo-os em argumentos de autoridade sobre os quais não cabem questionamentos. (...) por último, as iniciativas reformistas do conservadorismo dinâmico, ainda que paliativas, e sua ampla divulgação na mídia atuam no sentido de esvaziar a insatisfação pública e desmobilizar as possíveis reações das populações prejudicadas pelos efeitos da degradação ambiental" (op. cit. p. 126).

Assim, compreendo que uma proposta educativa relacionada à questão ambiental deve originar-se do desejo de contribuir para a "liberdade" do ser humano e não para a manutenção do seu estado de "servidão" e, para isso, deve-se primar por uma compreensão da educação enquanto resistência e busca da emancipação.

A tendência emancipatória de EA tem as seguintes características, segundo Lima (2002, p. 127) baseado em Carvalho (1991) e Demo (1999):

a) uma compreensão complexa e multidimensional da questão ambiental;

b) uma defesa do amplo desenvolvimento das liberdades e possibilidades humanas e não-humanas;

c) uma atitude crítica diante dos desafios da crise civilizatória;

d) uma politização e publicização da problemática socioambiental;

e) uma associação dos argumentos técnico-científicos à orientação ética do conhecimento, de seus meios e fins, e não sua negação; 
f) um entendimento da democracia como pré-requisito fundamental para a construção de uma sustentabilidade plural;

g) uma conviç̧ão de que o exercício da participação social e a defesa da cidadania são práticas indispensáveis à democracia e à emancipação socioambiental;

h) um cuidado em estimular o diálogo e a complementaridade entre as ciências e as múltiplas dimensões da realidade entre si, atentando-se para não tratar separadamente as ciências sociais e naturais, os processos de produção e consumo, os instrumentos técnicos dos princípios ético-políticos, a percepção dos efeitos e das causas dos problemas ambientais e os interesses privados (individuais) dos interesses públicos (coletivos), entre outros possíveis;

i) uma vocação transformadora dos valores e práticas contrárias ao bem-estar público.

Essa perspectiva nos convida a acreditar em algo irremediavelmente novo e ousado, que implica em nos despirmos das certezas e mergulhar conscientemente "num mar de incertezas ${ }^{9}$ " esperando encontrar do outro lado o mundo desejado.

Nesse sentido, a concepção de Educação Ambiental que permeou o referido curso enfatiza a participação como condição essencial para a transformação em direção do estabelecimento de uma sociedade mais justa, igualitária, ética e, portanto, feliz. E tem um compromisso irrestrito com a vida, com a liberdade e com a elevação de cada ser humano à condição de sujeito, não só de sua história, mas da história de todo um país, um planeta.

Para isso, é preciso considerar, nos projetos educacionais que compartilham dessa perspectiva, o educando como portador de direitos e deveres. Para tanto, o entendimento do acesso ao meio ambiente saudável deve estar aliado ao estímulo à participação social como uma prática que

\footnotetext{
${ }^{9}$ Morin, E. Os Sete Saberes necessários à Educação do Futuro, 2000.
} 
transforma a "consciência cidadã em ação social ou cidadania participante" (Lima, 2002, p. 134).

Por fim, deve-se pautar no que diz Carvalho (1992, p.33):

"É preciso recolocar os objetivos da prática educativa, situando-os para além da esfera comportamental. Se a educação quer realmente transformar a realidade não basta intervir na mudança dos comportamentos sem intervir nas condições do mundo em que as pessoas habitam... Neste sentido, podemos redefinir a prática educativa como aquela que, juntamente com outras práticas sociais, está implicada no fazer histórico, é produtora de saberes e valores e, por excelência, constitutiva da esfera pública e da política, onde se exerce a Ação humana".

Assim, a EA pode contribuir para ampliar e consolidar a cultura democrática e emancipatória na sociedade.

\subsection{A Universidade e a emergência de processos emancipatórios}

Percebe-se que, para que as modificações necessárias à implantação de processos emancipatórios ocorram de forma mais efetiva e abrangente é urgente a participação de diversas instâncias e instituições sociais, sendo a mais significativa a educação, a qual segundo Morin (2000) 'deveria mostrar e ilustrar o destino multifacetado do humano: o destino da espécie humana, o destino social, o destino histórico, todos entrelaçados e inseparáveis". E, dentre os espaços formais de ensino, a Universidade tem um papel essencial nessa reconfiguração do mundo.

É preciso, entretanto, debater sobre a função social da universidade, a partir da compreensão da necessidade de encontrar um novo equilíbrio entre a formação técnico/profissional e a formação humanista/cultural, o que 
implica ampliar o escopo das ações acadêmicas além da prestação de serviços ao mercado, conforme afirma Goergen(1998):

"O que queremos dizer é que o sentido social da universidade está sendo abreviado e reduzido à função de prestar serviços e cooperar com empresas. Sem negar que isto possa também ser socialmente relevante, acreditamos que o sentido social da universidade vai muito além disso. A universidade não pode mais voltar-se exclusivamente para o desenvolvimento unilateral da ciência e tecnologia como se esta perspectiva exaurisse o projeto humano. Há outras questões vitais para a sociedade e para a comunidade a partir das quais a comunidade decide seu futuro.(...) Ciência e tecnologia que encontram sua justificativa na eficiência assumem um papel fortemente ideológico na medida em que fogem da reflexão critica uma vez que as regras técnicas requerem aceitação incondicional. Parece-nos, por isso, que a universidade, para além de seus evidentes deveres no campo da ciência e tecnologia, seja capaz de reinventar uma cultura mais humana".

Assiste-se ao abreviamento do papel da universidade, de instância crítica da sociedade, a partir de interesses mais amplos e democraticamente discutidos, restringindo-se à formar mão-de-obra para o mercado, com o desenvolvimento da competência da competitividade já que novos empregos não são criados cabendo aos novos profissionais disputarem os atuais. Portanto, a situação apresenta-se mais complicada pois, além de ser uma instituição de pesquisa científica que favorece o capital, a universidade responsabiliza-se pela formação de um grande número de pessoas que não encontrarão trabalho, justamente devido aos avanços científicos que, para atender às demandas do mercado, resultaram em tecnologias para economizar mão-de-obra (Goergen, 1998). 
Nesse mesmo sentido Marilena Chauí (2001, p. 46), de maneira bastante contundente, enfatiza que:

"A universidade tem hoje um papel que alguns não querem desempenhar, mas que é determinante para a existência da própria universidade: criar incompetentes sociais e políticos, realizar com a cultura o que a empresa realiza com o trabalho, isto é, parcelar, fragmentar, limitar o conhecimento e impedir o pensamento, de modo a bloquear toda tentativa concreta de decisão, controle e participação, tanto no plano da produção material quanto no da produção intelectual. Se a universidade brasileira está em crise é simplesmente porque a reforma do ensino inverteu seu sentido e finalidade - em lugar de criar elites dirigentes, está destinada a adestrar mão-de-obra dócil para um mercado sempre incerto. E ela própria ainda não se sente bem treinada para isto, donde sua crise"'.

Goergen (1998) afirma que a universidade subordinou-se às normas de mercado, "passando a instrumentalizar pessoas para determinadas tarefas ao invés de formar indivíduos. O próprio indivíduo abriu mão de si mesmo, de sua formação como ser humano global (que conhece, sente, ama, chora e sofre) para atender exclusivamente aos requerimentos do sistema tecnoeconômico".

Para Santos (1997, p. 190) a universidade moderna, enquanto parte do paradigma da modernidade, está vivendo múltiplas crises, quais sejam: de hegemonia, de legitimidade e institucional, que se constituem em afloramentos da crise do paradigma que a sustenta. Por isso não é de estranhar que, apesar dessas evidências, a instituição encontre-se imobilizada, com suas atividades de ensino e pesquisa retratando a forte tensão entre as incertezas e as rápidas mudanças ocorridas, em escala mundial, no âmbito da sociedade. Ao analisar estas crises Santos (1997, p. 
187) não a considera preparada para defrontar estes desafios, tanto mais que os mesmos apontam a necessidade de transformações profundas e não de simples reformas parcelares. $\mathrm{O}$ autor conclui afirmando que:

"tal impreparação, mais do que conjuntural, parece ser estrutural, na medida em que a perenidade da instituição universitária, sobretudo no mundo ocidental, está associada à rigidez funcional e organizacional, à relativa impermeabilidade às pressões externas, enfim, à aversão à mudança."

Entretanto, o autor acredita na possibilidade de transformação da universidade, inclusive porque desta depende a sua sobrevivência no seio da sociedade contemporânea. E essa nova realidade que se delineia constituise em seu maior desafio. Santos (1997, p. 223) entende que a transição paradigmática de uma ciência moderna para uma ciência pós-moderna, atualmente vivenciada, conduz à reflexão de um outro modelo de universidade:

"A universidade que se quiser pautada pela ciência pós-moderna deverá transformar os seus processos de investigação, de ensino e de extensão segundo três princípios: a prioridade da racionalidade moralprática e da racionalidade estética-expressiva sobre a racionalidade cognitivo-instrumental; a dupla ruptura epistemológica e a criação de um novo senso comum; a aplicação edificante da ciência no seio de comunidades interpretativas" (Santos, 1997, p. 194).

Essa afirmação pauta-se na compreensão de que o imenso desenvolvimento científico atual, propiciado pela ruptura da ciência moderna para com o senso comum, trouxe consigo a penalidade da expropriação dos seres humanos, como cidadãos, da capacidade de participar no 
desvendamento do mundo e na construção de regras práticas para viver sabiamente.

Essa transição da universidade, entretanto, depende da ampliação do papel do cientista/intelectual para o de educador(a), que deverá desempenhar o seu trabalho com base na problematização teórica, considerando as questões sociais e políticos e objetivando desenvolver uma práxis comprometida com a construção de alternativas de vida. Trata-se de estabelecer uma outra relação pedagógica no seu interior.

Esses(as) educadores(as) devem desempenhar um papel crítico na apresentação de reflexões que apontem para desdobramentos e relações que estão além das definições visíveis, aparentes e unificadas da realidade social. Tal papel caminha, ainda, no sentido de revalorizar os saberes não científicos e o saber científico, subordinar o conhecimento técnico ao ético, buscando o compromisso da comunidade acadêmica com a sua aplicação.

Nesse sentido é interessante analisar o que diz Buarque ${ }^{10}$, citado por Santos (1997, p. 209):

"a política da universidade deve combinar o máximo de qualidade acadêmica com o máximo de compromisso social (...) O que caracterizará o produto, portanto, é a sua qualidade, sua condição de elite, mas o que caracterizará o seu uso é o seu compromisso amplo a sua condição antielitista. (...) Considera-se que o conhecimento científico, tecnológico e artístico gerado na Universidade e institutos de pesquisa não são únicos. Existem outras formas de conhecimento surgidas da prática de pensar e de agir dos inúmeros segmentos da sociedade ao longo de gerações que, por não serem caracterizados como científicas, são desprovidas de legitimidade institucional. Essas práticas estão sendo recuperadas à luz de uma actividade orgânica com a maioria da população". 
Santos (1997, p. 225) ressalta que a universidade não poderá desempenhar as suas funções a contento, nessa transição, se não dispor de autonomia institucional e de especificidade organizacional. Para garantir a capacidade de criação e a construção de uma nova sociedade é preciso romper as barreiras disciplinares e organizativas, transformando-se em

"uma anarquia organizada", feita de hierarquias suaves, nunca sobrepostas. Os centros dessa reorganização interna devem ser os cientistas/intelectuais, os alunos e os funcionários, compreendendo-se que "são todos docentes de saberes diferentes".

Daí, depreende-se que essa universidade pós-moderna deverá centrar suas ações de ensino, pesquisa e extensão, bem como sua estrutura organizacional, contemplando o que indica Santos (1997):

i) ruptura com a hegemonia da racionalidade cognitivo-instrumental como sustentação única do fazer ciência e com as hierarquizadas relações de poder que dividem os que fazem ciência, daqueles que ensinam e fazem extensão;

ii) reconhecimento de outros saberes e conhecimentos que não estão dentro da instituição, reconfigurando o senso comum e a ciência, as humanidades e as ciências naturais;

iii) a subordinação da aplicação técnica da ciência aos valores éticos (reflexivos) e morais (normativos) da vida social;

iv) a vivência da democracia através do desenvolvimento de comunidades argumentativas e interpretativas abertas à sociedade formadas por professores, funcionários e alunos que questionem os modos de vida, a disciplinariedade e todas as questões pertinentes ao viver e ao ser humano;

${ }^{10}$ Buarque, C. (1986, p. 22). 
v) pela produção de conhecimento que rompe fronteiras e se recrie e ressignifique constantemente face às realidades e mudanças da sociedade, dos processos de comunicação e de produção de vida material e da vida social e cultural.

Para construir esta universidade precisamos de um(a) educador(a) crítico e criativo, consciente de que sua formação pedagógica, no sentido do formativo e do educativo, se dará em um processo continuado de intervenções que acontecem de forma sistêmica, articulada e continuada no interior da própria instituição. É a constituição efetiva da "comunidade argumentativa e interpretativa', apontada por Santos, ou da "comunidade de aprendizagem", defendida por essa pesquisa.

Leite (1999) defende que essa formação deverá contemplar pelo menos três esferas do saber humano em ritmo de diálogo :

a) senso comum - memória e auto reflexão para a formação do ensinador interativo;

b) ciência - para formação do pesquisador e ensinador técnicoprofissional;

c) crítica filosófica - para a formação do crítico radical do conhecimento, de si e da sociedade.

Deverá ter, também, tantas vertentes e especificidades quantas forem necessárias para se construir uma "qualidade epistemológica nova" (Santos, 1989, p. 65) no fazer acadêmico.

A opção pela apresentação de uma reflexão sobre o papel da universidade na sociedade contemporânea, no âmbito desse estudo deve-se ao entendimento da necessidade premente de reconfiguração desse espaço no sentido de comprometê-la com uma revolução cultural permanente. É preciso dar o devido reconhecimento, no espaço acadêmico, às ações inovadores que buscam romper com a lógica preponderante quer nos microespaços - a sala de aula, por exemplo - ou em espaços mais amplos, tais como na relação universidade-comunidade. Essas ações fazem parte do 
cotidiano da universidade e não podem restringir-se mais ao caráter marginal que sempre lhes foi imputado, devendo ter centralidade nas discussões e reflexões sobre a nova universidade que se quer construir.

Por fim, o curso de especialização em Educação para Sociedades Sustentáveis caracteriza-se, enquanto proposta inovadora, diferindo da perspectiva reguladora por buscar, conforme Santos citado por Leite (1999, p.66): uma "ruptura" clara com os paradigmas vigentes na universidade (dos quais o positivista seria o mais conhecido) ou uma "transição" para um novo padrão ou ainda uma "reconfiguração" de saberes/poderes/conhecimentos. 


\section{METODOLOGIA}

\subsection{Método e procedimentos}

\begin{abstract}
"Assistimos ao surgimento de uma ciência que não mais se limita a situações simplificadas, idealizadas, mas nos põe diante da complexidade do mundo real, uma ciência que permite que se viva a criatividade humana como a expressão singular de um traço fundamental comum a todos os níveis da natureza”.
\end{abstract}

Ilya Prigogine

A sociedade contemporânea encontra-se em um profundo processo de transformação, o que indica que o próprio conhecimento científico está a se renovar e, nesse sentido, Morin ( 2000, p.41 ) afirma:

"estamos num período "entre dois mundos"; um que está prestes a morrer, mas que não morreu ainda, e outro, que quer nascer, mas que não nasceu ainda. Estamos numa grande confusão, num desses períodos angustiantes, de nascimentos, que se assemelham aos períodos de agonia, de mortes; mas creio que nessa grande confusão existam movimentos diferentes (...) para a reintrodução da consciência na ciência. 
A aposta não é simplesmente a aposta do enriquecimento do espírito dos cientistas, o que não seria mau. Não é somente a consciência no sentido da complexidade que uma visão mutilada das coisas havia eliminado, o que seria também muito bom! Penso ser uma aposta não somente científica. Mais do que isso: é profundamente política e humana, humana no sentido que concerne, talvez, ao futuro da humanidade."

A presente pesquisa parte da crença de que a crise, que expôs a fragilidade de um conhecimento assentado no reducionismo, na certeza, na objetividade e na simplificação, é irreversível abrindo enormes possibilidades para um "fazer científico" que considera que o "conhecimento só pode ser pertinente se ele situar seu objeto no seu contexto e, se possível, no sistema global do qual faz parte, se ele cria uma forma incessante que separa e reúne, analisa e sintetiza, abstrai e reinsere no concreto" (Morin, 2000, p.91).

À "ciência pós-moderna", como a denomina Boaventura de Sousa Santos (2001), cabe a tarefa de buscar a convergência entre o caráter científico e o caráter social. Mais do que isso, cabe instaurar uma nova prática científica que permita outra(s) leitura(s) da realidade e ou da sociedade, considerando as múltiplas perspectivas e possibilidades imersas nas articulações e a interdependência dos fenômenos que a compõem. A falibilidade e as incertezas devem ser compreendidas como atributos necessários para uma aproximação maior entre a ciência e a sociedade.

De acordo com esse entendimento, o conhecimento - científico ou não dá-se através do entendimento e da compreensão dos fenômenos vivos e dinâmicos, constituintes da realidade. Conforme Morin (2001:46):

"o conhecimento é uma aventura em espiral que tem um ponto de partida histórico, mas que não tem um fim, que deve, sem cessar, fazer círculos concêntricos, ou, melhor dizendo, que a descoberta de um princípio 
simples não tem fim; ela reconduz ao mesmo princípio simples que ele esclareceu em parte".

Japiassú (1995) afirma que a crise da ciência, em especial das ciências humanas e sociais, é reflexo de uma preocupação excessiva com a objetividade, com a positividade e com a pouca atenção dada a tudo o que não se prestasse facilmente "à modelização reducionista", resultando na omissão dos cientistas com os problemas e as questões que impactam a sociedade. Essas ciências adquiriram um caráter de despolitização ou "esterilidade política"11 exercendo, principalmente nos últimos séculos, um papel de meras fornecedoras de receitas prontas aos dirigentes de empresas e aos governantes.

Diante disso, o autor (op. cit., p.84-6) enfatiza que "jamais devemos agir em conformidade com os desejos dos outros (alienação)" e que "o intelectual define-se pelo interesse ou pela paixão por aquilo que escolheu como seu objeto: ele recusa que um objeto Ihe seja imposto pelo jogo da atribuição de subvenções ou de cargos. (...) Enfim, ele afirma-se como alguém que tem direito ao pensamento e à paixão por esse pensamento". Conclui ressaltando que "um dos papéis fundamentais que, historicamente, as ciências humanas se deram foi o da "crítica da ordem estabelecida, da denúncia dos privilégios abusivos e das dominações ilegítimas" e que se queremos saber qual a "direção" que as ciências humanas devem tomar "diria que elas deveriam restaurar sua função profunda: a de constituir o momento reflexivo por excelência da "invenção democrática".

Assim, necessita-se do estabelecimento de um outro modo de pensar e fazer e, conforme Carvalho (2001):

11 Neste caso o político é entendido como "a relação dos homens com o conflito e com a divisão social" ( Japiassú, 1995, p. 86) 
"esse é o papel reservado a intelectuais capazes de identificar no largo espectro das tensões sociais uma utopia social viável, uma arquitetura, ou seja, um paradigma da coerência construtiva que recombine tensões e integridades, razões e desrazões. Trata-se em resumo, de agir e participar sempre que possível, mesmo que a perdição seja grande e a tentação do refúgio paranóico maior ainda. A imagem do cientista ambicioso, isolado da natureza e dos afetos, criador de criaturas, deve ser superada, para dar lugar ao cientista amoroso, capaz de fazer dialogar o sensato e o insensato que sempre marcou a aventura humana".

O autor complementa afirmando que, "com isso, talvez seja possível aplacar os monstros da razão e perceber que a vida é bela, apesar das desavenças e domesticações que a historialidade imprimiu ao cientista, compelindo-o a optar entre um racionalismo redutor e um idealismo apaixonado".

Para Martins (2000) o conhecimento é construído no compartilhamento do processo investigativo entre o sujeito (que se torna objeto para a compreensão do outro) e o objeto (que se torna sujeito do processo de conversão do pesquisador). Assim, esse estudo tentou promover o encontro possível entre o meu compromisso, enquanto pesquisadora convertida a instrumento de interpretação de uma ação que também foi por mim vivida e influenciada e a tentativa de, para além de suas misérias e impasses, surpreender quem sabe em seus interstícios, os anúncios do imponderável, os sinais da criação.

A partir do diálogo com os autores supracitados assumo, nesta pesquisa, um método idiossincrático ${ }^{12}$, construído durante o próprio percurso. Para tanto, pautei-me, ainda, nas considerações de Becker (1994) sobre as singularidades

\footnotetext{
${ }^{12}$ Segundo Ferrreira (1993, p.292), refere-se à maneira própria de ver, sentir, reagir, de cada indivíduo.
} 
e especificidades de cada pesquisa e a liberdade que cada pesquisador deve ter para construir seu próprio método, de acordo com as condições da pesquisa. Nesse sentido, o autor ressalta que "é como mandar construir uma casa para si. Embora existam princípios gerais de construção, não há dois arquitetos com as mesmas necessidades. Assim, as soluções para os problemas de construção têm que ser sempre improvisadas" (op. cit., p.12).

Tenho ciência, contudo, de que este estudo encontra-se repleto de lacunas e de que as reflexões necessitam ainda de um maior aprofundamento. Acredito, porém, que tais fatos podem ser explicados através da afirmação de Fazenda (1995, p.14):

"quando a pesquisa dos iniciantes defronta-se com o dilema da pesquisa, é prisioneiro do desejo de ir além, de criar de inovar, de caminhar em direção ao que ainda não é. Porém como não sabe quem é fica impedido de transgredir seus próprios limites".

Para um melhor entendimento sobre o caminho percorrido por esta pesquisa apresento, a seguir, considerações sobre métodos e técnicas utilizadas.

\subsubsection{Pesquisa Qualitativa}

Pelas características do problema proposto optei pela realização de uma pesquisa de abordagem qualitativa que busca captar a realidade dinâmica e complexa do objeto de estudo no seu contexto histórico. Conforme Minayo (1994, p.21-2) esta pesquisa:

"trabalha com o universo de significados, motivos, aspirações, crenças, valores e atitudes, o que corresponde a um espaço mais profundo das 
relações, dos processos e dos fenômenos que não podem ser reduzidos à operacionalização de variáveis. (...) Enquanto cientistas sociais que trabalham com estatística apreendem dos fenômenos apenas a região "visível, ecológica, morfológica e concreta", a abordagem qualitativa aprofunda-se no mundo dos significados das ações e relações humanas, um lado não perceptível e não captável em equações, médias e estatísticas."

Destaca-se, dessa abordagem, as seguintes características, conforme Bogdan e Biklen (1982) citados por Ludke e André (1986, p.11-13):

- o ambiente natural como sua fonte de dados, sendo que estes se apresentam predominantemente explicativos;

- o processo é mais importante do que o produto;

- o foco de atenção do pesquisador está, especialmente, no significado que as pessoas dão as coisas e à sua vida;

- preocupação em retratar a perspectiva dos participantes; e

- a análise dos dados tende a seguir um processo indutivo.

Contudo, a subjetividade e a complexidade inerentes a este campo do conhecimento, exigem análises que vão além do estudo fragmentado e ou reducionista dos fenômenos, necessárias à compreensão do todo.

Cabe ressaltar que essa pesquisa trilhou um percurso entre o empírico e o teórico o que possibilitou desdobramentos que contribuíram para redefinir o próprio projeto, as hipóteses e as abordagens metodológicas.

\subsubsection{Estudo de caso}

Dentre os vários tipos de abordagens qualitativas, optou-se por realizar um estudo de caso, visto "o desejo de entender um fenômeno social complexo" (Yin, 2001) e, por entender que o seu foco central refere-se à tentativa de 
esclarecer "uma decisão ou um conjunto de decisões: porque elas foram tomadas? Como elas foram implementadas? Quais os resultados alcançados" (op. cit.).

Segundo Becker (1994:118-9) o estudo de caso tem duplo propósito: "Por um lado, tenta chegar a uma compreensão abrangente do grupo em estudo (...). Ao mesmo tempo, tenta desenvolver declarações teóricas mais gerais sobre regularidade do processo e estruturas sociais (...). " Dessa forma não pode ser concebido "segundo uma mentalidade única para testar proposições gerais. (...) tem que ser preparado para lidar com uma grande variedade de problemas teóricos e descritivos. (...) Assim postos, os objetivos do estudo de caso mal podem ser conscientizados; é utópico supor que se pode ver, descrever e descobrir a relevância teórica de tudo."

Nesse contexto, mesmo que o(a) pesquisador(a) não consiga alcançar as metas estabelecidas, devido à abrangência do estudo de caso, o trabalho terá sido importante por prepará-lo(a) para lidar com descobertas inesperadas e força-o(a) a considerar, "por mais que de modo rudimentar, as múltiplas interrelações dos fenômenos específicos que observa", evitando pressuposições que podem se revelar incorretas sobre questões relevantes para a sua pesquisa (op. cit., p.19).

Outro ponto que considero importante e que me fizeram optar por este método encontra-se na formulação de Hoppen (1996) ao afirmar que não há manipulação ou controle dos sujeitos pelo pesquisador e, além disso, permite estudar fenômenos que estão em curso e ou os que já aconteceram. 


\subsubsection{Procedimentos}

Nisbet e Watt citados por Ludke \& André (1986), indicam três fases presentes no estudo de caso : a primeira é chamada de aberta ou exploratória, a segunda é mais sistemática em termos de coleta de dados e a terceira é a análise dos dados e a elaboração do relatório.

A fase exploratória coloca-se como fundamental para a definição mais precisa do objeto de estudo. É o momento de especificar os pontos críticos, de estabelecer os contatos iniciais para a entrada em campo, de localizar os informante e as fontes de dados necessário para o estudo.

Neste caso, tal fase iniciou-se na época em que a pesquisadora atuou como coordenadora do referido curso, realizando as seguintes atividades: i) elaboração da proposta político pedagógica do currículo do curso; ii) colaboração no processo de seleção dos alunos; iii) ministrante de aulas da disciplina Educação Ambiental e Agenda XXI Local; iv) acompanhamento cotidiano das aulas de nove das dez disciplinas; v) acompanhamento dos projetos de intervenção educacional desenvolvidos pelos alunos nas diferentes comunidades; vi) avaliação dos alunos.

Os contatos e a convivência, possibilitados nessa fase, foram extremamente importantes para a identificação dos elementos-chave e a delimitação do problema, bem como para a elaboração dos critérios para a escolha do estudo de caso. Nesse sentido, consolidou-se a opção por investigar a proposta educacional do curso de Especialização em Educação para Sociedades Sustentáveis, da Universidade estadual do Sudoeste da Bahia, campus de Jequié-BA e o seu impacto no cotidiano dos especialistas egressos.

Durante o curso atuei como observadora-participante, registrando todo o processo em um caderno de anotações, onde constavam os registros referentes às questões administrativas e pedagógicas a serem resolvidas e, também, o registro de observações, atividades e reflexões sobre o processo em curso. Estas anotações foram importantes para o repensar constante sobre o 
desenrolar do curso e, também, para a posterior análise necessária a esta pesquisa. Durante esse tempo foram realizadas gravações em fita cassete e VHS que registraram diferentes momentos do curso e que serviram como um precioso auxílio para a tentativa de apreensão daquele processo.

\subsubsection{Coleta de dados}

Dentre os procedimentos indicados para coleta de dados em estudo de caso utilizei a análise documental, que complementa os dados obtidos através da observação e que aponta novos aspectos da realidade pesquisada. Além disso realizei entrevistas com os estudantes egressos do curso por considerar que a mesma permite um maior aprofundamento das informações obtidas (Ludke \& André, 1986).

Foram analisados os seguintes documentos produzidos no decorrer do curso por alunos, comunidade estudada e coordenação:

i) O projeto político pedagógico e a proposta curricular elaborados pela coordenação do curso;

ii) Os questionários respondidos pelos alunos no processo seletivo para o ingresso no curso;

iii) Os sete projetos de intervenção educacional e respectivos relatórios das atividades desenvolvidas pelos grupos; $\mathrm{e}$

iv) O caderno de campo da pesquisadora e do(a)s vinte e sete estudantes que concluíram todas as etapas do curso, com registro das atividades realizadas e das reflexões advindas daquele processo.

As entrevistas semi-estruturadas foram realizadas, em janeiro de 2001, com onze especialistas egressos do curso e desenvolveram-se "a partir de um esquema básico, porém não aplicado rigidamente, permitindo que o entrevistador faça as necessárias adaptações", conforme enfatizam Lüdke e André (1986, p.34). Através das entrevistas objetivava apreender o significado 
do referido curso, tanto na vida pessoal quanto na profissional, além das transformações na subjetividade, os limites, os conflitos decorrentes dessa experiência e a trajetória dos grupos (Sacardo, 2001:43).

Procurei entrar em contato com todos os egressos do curso para serem entrevistados, contudo, por motivos diversos - período de férias escolares, mudança de cidade, dentre outros -, apenas onze se dispuseram a participar de uma conversa e responder às questões estabelecidas. Duas, entretanto, optaram por responder aos questionamentos por escrito. Outra questão que procurei esclarecer aos entrevistados referia-se à importância de expressarem livremente suas opiniões acerca do curso, visto que a análise e o planejamento destes programas dependia destas informações.

Estas atividades foram realizadas nas dependências da UESB e residência de uma das entrevistadas, sendo gravadas com autorização prévia dos(as) mesmos(as) e, posteriormente, transcritas.

\subsubsection{Análise e interpretação dos dados}

Segundo Minayo (1994,p.69) esta etapa pode ter três finalidades: "estabelecer uma compreensão dos dados coletados, confirmar ou não os pressupostos da pesquisa e/ou responder às questões formuladas, e ampliar o conhecimento sobre o assunto pesquisado, articulando ao contexto cultural da qual faz parte". A autora ressalta que essas finalidades são complementares.

Para a operacionalização da análise as fitas cassetes foram transcritas literalmente e após "ler e reler o material até chegar a uma espécie de “impregnação" do seu conteúdo" (Michelat apud Ludke \& André, 1986:48) procurei identificar os temas relevantes e recorrentes, assim como as idéias contraditórias e as centrais, visando o estabelecimento das categorias descritivas. 
Adotei o mesmo procedimento para a leitura e análise dos cadernos de campo e dos projetos/relatórios da intervenção educacional realizada pelos estudantes.

Concordando com Ludke \& André (1986) que a categorização por si só não esgota a análise, sendo necessário ir além ultrapassando a mera descrição, buscando acrescentar algo à discussão já existente sobre o assunto focalizado, procurei relacionar os dados categorizados às descobertas feitas durante a pesquisa bibliográfica, principalmente com base na obra do filósofo Baruch de Espinosa e, posteriormente, com base nas reflexões de Bader Sawaia (2001) e Sacardo (2001) que, em sua pesquisa de doutorado, trabalhou com proposta semelhante.

$\mathrm{Na}$ tentativa de assegurar um entendimento mais aprofundado da questão em foco, busquei utilizar a técnica da triangulação, haja vista a sua contribuição na convergência entre diferentes pesquisas e diferentes teorias, conforme Huberman e Miles (1994, p.438).

Denzin (1978) citado por Janesick (1994, p.209) apresenta quatro tipos de triangulação, quais sejam:

i) a triangulação de dados, que consiste na utilização de múltiplas estratégias de amostragem;

ii) a triangulação de pesquisadores, que baseia-se no uso de diversos pesquisadores ou avaliadores;

iii) a triangulação de teorias, que utiliza variadas perspectivas na interpretação de um único tipo de dado;

v) a triangulação metodológica, que consiste na utilização de múltiplos métodos para estudar um único problema.

Assim, utilizei a triangulação de dados e de teorias para analisar as informações coletadas e, a partir desta análise elaborar uma síntese ou, no caso específico, as considerações referentes ao estudo realizado. 


\subsection{Cenário de Estudo}

Cidade de Jequié... Tanta beleza

Por vales e montanhas circundada, Parece até que a própria Natureza Plantou naquele chão sua morada! Pacífico Ribeiro

A idéia inicial deste estudo era de, a partir dos docentes, dos coordenadores e dos estudantes/especialistas egressos, realizar a análise do curso. Contudo, após algumas reflexões e devido à escassez de tempo, optei por enfocar o estudo apenas nos estudantes/especialistas egressos.

Nesse sentido, é interessante traçar o perfil de cada um, a fim de possibilitar uma análise mais contextualizada. Contudo, antes de apresentá-los, considero pertinente falar um pouco de Jequié e da UESB, espaços em que aconteceram o curso.

O município de Jequié, emancipado em 25 de outubro de 1897, situa-se no sudoeste da Bahia, a $360 \mathrm{~km}$ de Salvador pela BR 116 e possui uma população estimada em 147.202 habitantes (IBGE, 1999 citado por UESB, 2002). A sede do município está situada às margens do Rio das Contas com altitude de até $100 \mathrm{~m}$, circundada por elevações que variam de 200 a $800 \mathrm{~m}$. Ocupando uma área de $3.013 \mathrm{~km}$, possui um clima semi-árido, com uma temperatura média de $23,33^{\circ} \mathrm{C}$ e caracteriza-se por ser uma zona de transição entre a mata atlântica e a caatinga, "abrangendo paisagens naturais e humanas diferentes, até opostas: a zona semi-árida, onde se cria o gado e se sofre de seca, e a zona úmida, onde se planta o cacau e chove todo ano", conforme Milton Santos (s.d) citado por UESB (2002).

Seu artesanato é ricamente diversificado, bem com suas manifestações culturais, o que torna Jequié uma cidade singular na região, dispondo, inclusive, 
de uma Casa de Cultura e um Teatro Municipal com capacidade para 800 pessoas.

A pecuária (especialmente os bovinos, galináceos e caprinos) e a agricultura (destacando-se o cacau e o café) formam a base do seu desenvolvimento econômico. Além dessas atividades o município conta com o incremento de sua economia a partir da implantação de várias indústrias de confecção, gêneros alimentícios e, sobretudo, do poliduto de derivados de petróleo e álcool, o que proporcionou a instalação na região das maiores empresas do setor (UESB, 2002).

$\mathrm{Na}$ área educacional Jequié conta com 28 estabelecimentos de ensino fundamental pertencentes à rede estadual e 114 unidades escolares mantidas pelo sistema municipal, das quais 88 funcionam na zona rural. No ensino médio a rede estadual conta com 6 instituições. Na rede privada existem 36 instituições de ensino fundamental, entre as quais 5 também atendem ao ensino médio (INEP, 2000 citado por UESB, 2002).

No ensino superior público, o município conta com um campus da Universidade Estadual do Sudoeste da Bahia - UESB que oferece os cursos de Bacharelado em Enfermagem, Ciências Biológicas e Fisioterapia; cursos de licenciatura em Letras, Educação Física, Química, Pedagogia, Matemática e Ciências Biológicas. O campus de Jequié se destaca por manter a matrícula de 6.124 alunos nos cursos de graduação e uma média de 195 alunos em cursos de pós-graduação lato sensu, contribuindo para a melhoria do nível sócioeconômico-cultural de toda a microrregião. O município conta, ainda, com duas faculdades da iniciativa privada: Faculdades Integradas de Ciências Contábeis e de Administração de Jequié e Faculdade de Tecnologia e Ciência.

A UESB é uma instituição multicampi, com sede no município de Vitória da Conquista e dois campi nos municípios de Itapetinga e Jequié, criada em 1981 em atendimento à política de expansão e interiorização do ensino superior, iniciado pelo governo estadual na década de 70. Com essa iniciativa o Governo Estadual objetivava a descentralização do ensino superior na Bahia e 
a quebra de uma tradição de universidades nas regiões litorâneas, enquanto o sertão ficava esquecido e o seu povo sem acesso aos benefícios oriundos dessas instituições (UESB, 2002).

Com vinte e um anos de funcionamento, A UESB é uma instituição que vem desenvolvendo um trabalho acadêmico reconhecido por toda comunidade e registra um crescimento espetacular, qualitativo e quantitativo, nas atividades de ensino, extensão e pesquisa. Esse crescimento tem contribuído de maneira significativa para o desenvolvimento da região, através do incremento da sua economia com a produção de novos conhecimentos que atendem às demandas, principalmente, dos setores vinculados à agropecuária e ao meio ambiente. Além disso, trouxe para o município de Jequié um número considerável de estudantes, oriundos de outros municípios e estados, o que movimenta os setores da economia, da cultura e do lazer.

Nesse momento, faz-se necessário apresentar os sujeitos dessa pesquisa. Optei por não identificá-los pelos nomes e, sim, por usar essa codificação, composta pela letra $\mathrm{E}$, referente ao termo estudante e ou especialista egresso, mais a numeração arábica que corresponde à ordem alfabética dos nomes. Utilizei, para compor os perfis, as informações constantes no questionário preenchido para a inscrição no curso, assim como, os dados contidos na matrícula e fornecidos pela Secretaria Setorial de Cursos, da UESB-campus de Jequié.

- E 1 - Bióloga, 34 anos, professora de Ciências e Geografia no ensino fundamental e médio, respectivamente, da rede publica do Estado da Bahia, casada. Residente em Jequié-BA.

- E 2 -Licenciada em Letras (Português), 29 anos, professora de Língua Portuguesa no ensino fundamental da rede municipal (Jequié) de ensino, solteira. Residente em Jequié- BA.

- E 3 - Bióloga, 37 anos, professora no ensino fundamental da rede publica do Estado da Bahia, casada. Residente em Jequié- BA. 
- E 4 - Licenciada em Letras (Português), 37 anos, professora de Língua Portuguesa no ensino fundamental da rede municipal (Itaquara-Ba) de ensino, solteira. Residente em Itaquara- BA.

- E 5 - Biólogo, 33 anos, funcionário público municipal - vigilância sanitária, solteiro. Residente em Jequié- BA.

- E 6 - Bióloga, 58 anos, professora do ensino fundamental da rede pública estadual, solteira. Residente em Jequié- BA.

- E 7 - Pedagoga, 35 anos, professora do ensino médio da rede pública Estado da Bahia, casada. Residente em Jequié- BA.

- E 8 - Licenciada em Química, 26 anos, desempregada, solteira. Residente em Jequié- BA

- E 9 - Geógrafa, 36 anos, professora do ensino fundamental da rede pública estadual, casada. Residente em Jequié- BA.

- E 10 - Engenheiro Agrônomo, 44 anos, autônomo presta assessoria à Prefietura Municipal de Jequié e outros em projetos agropecuários de desenvolvimento na área rural, com ênfase para irrigação e projetos comunitários , casado. Residente em Jequié- BA.

- E 11 - Biólogo, 36 anos, professor de Ciências e Biologia no ensino fundamental e médio, respectivamente, da rede pública estadual e, também, técnico administrativo da UESB, casado. Residente em Vitória da Conquista, a cerca de $160 \mathrm{~km}$ de Jequié- BA

- E 12 - Biólogo, 42 anos, professor do ensino fundamental da rede pública municipal, casada. Residente em Jequié- BA.

- E 13 - Assistente social, 35 anos, funcionária da Prefeitura do Município de Aiquara, casada. Residente em Aiquara- BA.

- E 14 - Biólogo, 31 anos, fiscal de tributos da Prefeitura Municipal de Jequié / Departamento de Tributação, casado. Residente em Jequié- BA.

- E 15 - Bióloga, 45 anos, professora de Biologia no ensino médio da rede pública estadual de ensino, casada. Residente em Jequié- BA. 
- E 16 - Licenciada em História, professora do ensino fundamental da rede pública municipal, casada. Residente em Jequié- BA.

- E 17 - Engenheiro Agrônomo, 34 anos, Mestre em Meteorologia Agrícola, funcionário da Empresa Baiana de Desenvolvimento Agrário - EBDA, desenvolve pesquisas na área de Agrometeorologia, Simulação de Crescimento da Cultura do arroz (modelagem) e Cotonicultura (com ênfase no Manejo Integrado de Pragas); atua ainda como professor de ciências na rede pública estadual de ensino, casado. Residente em Barreiras- BA, a cerca de $800 \mathrm{~km}$ de Jequié- BA.

- E 18 - Licenciada em Química, 32 anos, professora de quimica no ensino médio da rede pública estadual e privada de ensino, casada. Residente em Jequié- BA.

- E 19 - Geógrafa, 50 anos, professora de Geografia no ensino fundamental e médio da rede pública estadual e privada, casada. Residente em JequiéBA.

- E 20 - Bióloga, 27 anos, atua como técnica em Educação Ambiental em um trabalho desenvolvido pelo WWF em llhéus- BA, casada. Residente em Ilhéus- BA a cerca de $200 \mathrm{~km}$ de Jequié- BA.

- E 21 - Engenheiro agrônomo, 48 anos, Especialista em Metodologia de Extensão Rural, agente de desenvolvimento do Banco do Nordeste do Brasil, casado. Inicialmente residia em Jequié- BA, sendo posteriormente transferido para Aracaju-Se.

- E 22 - Biólogo, 39 anos, professor de matemática no ensino médio da rede pública municipal de ensino, casado, residente em Jequié- BA.

- E 23 - Bióloga, 40 anos, professora de Ciências Físicas e Biológicas no ensino fundamental da rede pública estadual de ensino, casada. Residente em Jequié- BA.

- E 24 - Biólogo, 42 anos, professor de Física no ensino médio da rede pública Estado da Bahia, casado. Residente em Jequié- BA. 
- E 25 - Economista, 32 anos, atua como Supervisora da Universidade Nacional de Brasília (CESPE / BNB) no Programa de Melhoria das Agências da Previdência Social em Jequié e ministra aulas particulares de matemática, solteira. Residente em Jequié- BA

- E 26 - Bacharel em Ciências Contábeis, 38 anos, professora de Ciências no ensino fundamental da rede pública municipal e estadual de ensino, solteiro. Residente em Jequié- BA.

- E 27 - Sociólogo, 31 anos, professor substituto de Sociologia e Cultura e Sociedade da Universidade Estadual do Sudoeste da Bahia, solteiro. Residente em Ilhéus- BA.

- E 28 - Filósofa, 37 anos, professora de Sociologia e Filosofia no ensino médio da rede pública estadual de ensino, casada, residente em Vitória da Conquista- BA.

É importante registrar que desses vinte e oito sujeitos que concluíram todas as etapas do curso, três foram reprovados e que, desse universo, apenas onze foram entrevistados. Contudo, utilizei para a coleta de dados, os vinte e oito cadernos de campo e sete relatórios elaborados. 


\section{RESULTADOS E DISCUSSÃO}

Esse capítulo destina-se à apresentação dos resultados e discussão sobre o curso de Especialização, objeto deste estudo, e divide-se da seguinte forma:

- Em um primeiro momento procuro apresentar o projeto políticopedagógico implementado. Recorri, para tanto, à proposta elaborada pela equipe coordenadora e apresentada aos/às estudantes no início do curso, conforme Anexo A. Serão utilizados, ainda, os registros feitos por mim em um caderno de campo e do aporte teórico de alguns autores que auxiliaram na compreensão e definição de todo o processo.

- Em seguida, busco apresentar o curso a partir da perspectiva dos/as estudantes com base, essencialmente, na interpretação das falas constantes nos cadernos de campo, portanto registros feitos no decorrer do processo educativo, e das entrevistas, realizadas cerca de um ano após o término do curso. Aqui, também, busco o auxílio de autores que contribuíram na tessitura desse estudo para subsidiar a reflexão. 


\title{
4.1 O Curso de Especialização
}

\begin{abstract}
"Independentemente de onde nos posicionamos nas esquinas da história, nossa localização é sempre precária e arriscada. Embora sejamos constantemente tentados/tentadas a ver além da agonia do momento presente num sublime abismo do desconhecido, não podemos evitar o encontro com a violenta colisão entre trabalho e capital. Estamos numa conjuntura peculiar na história da humanidade, que nos atormenta com a promessa de redenção e libertação, enquanto fornece sua ameaça de corrupção e desespero. Estamos pendurados/penduradas precariamente entre a revolução e a contra-revolução..."

Peter McLaren e Ramin Farahmandpur
\end{abstract}

O Curso de especialização foi elaborado e implementado pelo Departamento de Ciências Biológicas da Universidade Estadual do Sudoeste da Bahia - DCB/UESB, no período de fevereiro de 2000 e maio de 2001. Surgiu da iniciativa de docentes das universidades de São Paulo e Estadual do Sudoeste da Bahia, USP e UESB, respectivamente, que tornaram-se parceiros a partir da convergência dos ideais e idéias sobre universidade, educação e sociedade. Tal parceria efetivou-se através de um convênio de cooperação técnica, assinado em 1999, entre as universidades supracitadas, passando a contar, também, com a parceria informal da Equipe de Educação Ambiental da Universidade Estadual de Feira de Santana (UEFS).

A compreensão de que uma das possibilidades para a reinvenção do futuro, no caminho apontado por Boaventura Sousa Santos $(1997,2000)$, 
passa por uma ação educativa comprometida com a transformação da sociedade culminou na opção pela elaboração, planejamento e implementação de um programa de Educação Ambiental voltado para a formação de educadores ambientais que, em sua ação educativa, promovessem a formação de outros agentes de sustentabilidade socioambiental. Esses programas previam a realização de cursos de especialização para atender aos objetivos mencionados anteriomente.

O curso apoiava-se no conceito de sociedades sustentáveis em detrimento do conceito de desenvolvimento sustentável. Contudo, ao final do curso, observa-se que tal perspectiva não foi incorporado pelos/as estudantes da maneira como foi concebido.

Esse conceito, elaborado originalmente pelo World Watch Institute, sob a liderança de Lester Brown, foi disseminado mundialmente e passou a ser, simultaneamente, uma idéia força poderosíssima sobre a ordem social desejável e um campo de batalha simbólico para o significado desse ideal normativo (Ferreira e Viola, 1996). Segundo Sorrentino (2000) tal conceito congrega os setores que sempre estiveram em oposição ao atual modelo de desenvolvimento e que acreditam que as correntes do ecodesenvolvimento e do desenvolvimento sustentável são apenas uma roupagem nova para a manutenção do "status quo" e aponta alguns aspectos que definem a sua identidade:

a) Propósito convergente de construírem uma sociedade mais justa, igualitária e ecologicamente equilibrada;

b) compartilhar da premissa de que o respeito à natureza é inalcançável num quadro de desrespeito e aviltamento do ser humano que a integra; e

c) convicção comum de que, para se chegar a essa sociedade mais justa e ecológica é necessário mudar o sujeito do desenvolvimento, colocando o povo como autor e gestor do seu projeto de modernidade. 
Nesse sentido, os cursos implementados refletiam a opção política ${ }^{13}$ dos seus idealizadores os quais, entendendo que a ação educativa deve promover e impulsionar a concretização de um projeto histórico, buscaram a viabilização de um projeto alternativo de educação no interior das instituições universitárias, através do estabelecimento de espaços de locução, tendo como marcos a criticidade, autonomia, solidariedade, criatividade, afetividade, alteridade e o diálogo.

Dessa forma, compreendo que o curso não vislumbrava apenas a capacitação técnica dos sujeitos, mas também a sua preparação e formação política. Dessa forma, destaco as seguintes razões como fundamentais para a efetivação desta parceria e implementação do curso:

a) A necessidade de preparação de profissionais, não apenas intelectualmente, mas também no que se refere ao compromisso ético e político, para atuarem no campo sócioambiental; e

b) A necessidade do estabelecimento de uma cultura universitária permeada pelo debate lúcido das questões que impactam a sociedade, a fim de uma atuação ética e propositiva.

Segundo Gutiérrez (1988, p.47), o projeto alternativo em educação pressupõe a transformação radical dos sistemas de ensino de modo a tornar possível a "criação de uma cultura alternativa como expressão de um homem novo" ${ }^{14}$ e, sustenta que os dois processos terão de ocorrer pela inter-relação e dependência que guardam entre si, visto que não existe "um novo homem sem a mudança das estruturas sociais, nem mudança das estruturas sociais sem a formação do homem pretendido por essa nova sociedade. Uma consciência nova e um novo comportamento social só podem ocorrer em e com a recriação de uma nova ordem social" (op.cit., p.47-8).

\footnotetext{
${ }^{13}$ Gutiérrez (1988, p.44-5 ) "Opção política é, portanto, tomar partido frente à realidade social, é não ficar indiferente ante a injustiça atropelada, a liberdade infringida, os direitos humanos violados, o trabalhador explorado. Tomar partido pela justiça, pela liberdade, pela democracia, pela ética, pelo bem comum, é opção política, é o fazer político.”

${ }^{14}$ Girardi, 1977, p.86.
} 
Com essa perspectiva, o projeto político-pedagógico do curso procurou nortear suas atividades tendo como finalidade a emergência de um educador ambiental que, para além dos conhecimentos e aptidões adequados à uma atuação competente, apreendesse ao longo do processo educativo que a redefinição dos contornos sociais requer, acima de tudo, uma ação responsável, crítica, criativa, solidária e comprometida com os valores de uma sociedade efetivamente democrática.

Inicialmente, o projeto do curso, previa o desenvolvimento das ações em quatro etapas articuladas e interdependentes: i) capacitação do corpo docente da UESB para implementar um curso de especialização; ii) esses docentes formariam especialistas que deveriam iii) capacitar estudantes de graduação para atuarem em municípios parceiros na iv) identificação e capacitação de pessoas daquelas comunidades como agentes locais de sustentabilidade.

Contudo, por diversos motivos, não foi possível atender ao planejamento. Não houve a realização de atividades que promovessem a articulação e capacitação do corpo docente da UESB em torno da proposta político-pedagógica elaborada. Além disso, o curso não adotou a capacitação dos alunos de graduação como uma ação relacionada à formação dos especialistas, tendo os mesmos atuado diretamente nas comunidades, através da realização de projetos de intervenção educacional voltados à formação de agentes locais de sustentabilidade.

Assim, o desenvolvimento do mesmo ocorreu da seguinte forma: os docentes da UESB e convidados de outras instituições atuaram na formação dos especialistas que desenvolveram projetos de intervenção educacional em comunidades de sua escolha objetivando a formação de agentes locais. Optou-se por dividi-lo em três módulos: informativo, estruturante e de intervenção (Anexo A).

Para atender aos objetivos definidos anteriormente, as ações foram planejadas e implementadas em módulos simultâneos e articulados de 
maneira a possibilitar que os participantes realizassem atividades de Ensino, Pesquisa e Extensão, focadas na formação de agentes locais.

Compreendendo que todo processo político-educativo objetiva "o desenvolvimento das capacidades e dos potenciais de cada educando/educador para sentir, pensar e agir de forma autônoma, crítica e criativa, no contexto dos grupos sociais em que vive" (Graciani, 1999, p. 72), elegeu-se a pedagogia da práxis, a comunidade de aprendizagem e a disponibilização de informações como eixos articuladores do curso.

A opção pela pedagogia da práxis deve-se ao entendimento de que a educação na práxis é "uma ação transformadora consciente que supõe dois momentos inseparáveis, o da ação e o da reflexão, sendo o primeiro o ponto inicial, na medida em que a ação parte de uma certa consciência e conduz até uma nova forma de consciência, mais esclarecida, mais plena" (Gutiérrez, 1988, p.107). O autor afirma, ainda, que "nem a ação excessiva e mecanizada, nem a mais encantadora teoria conscientizadora, levam à verdadeira práxis" (op.cit, p.106).

Dessa forma, a dimensão da práxis foi contemplada através do desenvolvimento de projetos de intervenção educacional em comunidades locais. Assim, os estudantes atuaram como mediadores da construção do conhecimento dos integrantes daquelas comunidades, a partir do confronto com a realidade concreta e da análise das situações vividas, com o propósito de recriá-las de acordo com um outro nível de consciência, adquirido nesse processo de ação-reflexão-ação.

Nesse sentido, os estudantes utilizaram como caminho metodológico a formação de Grupos de Pesquisa-Ação Participativa (PAP), constituídos por pessoas das comunidades locais, procurando identificar e propor ações para os problemas detectados. Como estratégias e ou técnicas para a constituição dos grupos PAP, identificação dos problemas a serem trabalhados desenvolveram o "olhar distraído", a "Oficina de Futuro" e a "Agenda 21 do Pedaço ". O olhar distraído é uma técnica adaptada do 
método etnográfico que permitiu aos alunos o conhecimento da comunidade escolhida para a atuação a partir de contatos informais, andanças pelo local na tentativa de identificar lideranças, grupos, associações que pudessem propiciar a entrada naquela comunidade. Além disso possibilita uma aproximação desarmada da realidade a ser trabalhada.

A Oficina de Futuro, criada pelo Instituto Ecoar para a Cidadania, consiste em estratégia utilizada para estimular e propiciar a participação de todos os integrantes do grupo PAP na reflexão e no mapeamento dos problemas do dia-a-dia, no diagnóstico da realidade local e dos sonhos para a construção de um mundo melhor. Essas Oficinas compõem-se em três momentos : a construção da Árvore dos Sonhos em que vislumbram-se os desejos, individuais e coletivos, de transformação do mundo em um pedaço bonito, solidário e com igualdade de oportunidades para nós e para as gerações futuras; a montagem do Muro das Lamentações que consiste na indagação de como chegou-se a atual situação e o que dificulta a concretização dos sonhos; o terceiro momento constitui-se na formulação participativa de um projeto transformador, que emerge da dialética entre o sonho e as dificuldades, entre a paixão e a resistência (Trajber \& Costa, 2001:22)

Com a comunidade de aprendizagem pretendia-se estabelecer um processo que promovesse a implicação ${ }^{15}$ dos sujeitos no seu próprio processo formativo. E partia do pressuposto de que o conhecimento gerado a partir da prática e através do diálogo reflexivo com os outros sujeitos da aprendizagem, em um processo que coloca o sujeito em formação no centro da ação educativa, conduz à construção de um conhecimento realmente incorporado, porque produzido por si e para si.

\footnotetext{
${ }^{15}$ Segundo Burnham (1998, p.42), Barbier (1985, p.120) definia por implicação “o engajamento pessoal e coletivo do pesquisador por sua práxis científica, em função de sua história familiar e libidinal, de suas posições passadas e atual nas relações de produção e de classe, e de seu projeto sócio-político em ato, de tal modo que o investimento que resulte inevitavelmente de tudo isso seja parte integrante e din6amica de toda atividade do conhecimento"
} 
Mais do que isso, a comunidade de aprendizagem pressupõe a solidariedade, a construção de conhecimentos compartilhada entre a comunidade, os alunos e os docentes do curso. Representa, assim, a construção e a consolidação das oportunidades de aprendizagem.

O terceiro eixo, da disponibilização de informações, partia do pressuposto de que não há uma informação única a ser trabalhada e, sim, que existe uma multiplicidade de idéias e de conhecimentos que deveriam ser acessados pelos estudantes à medida que sentissem necessidade. $O$ curso, através das disciplinas oferecidas (Anexo A), abordou alguns conteúdos considerados importantes para o entendimento da proposta educativa em desenvolvimento, assim como para a atuação competente de um educador ambiental para sociedades sustentáveis.

Essas disciplinas ficaram sob a responsabilidade de seis professores da própria UESB e quatro de outras instituições (USP, UEFS e Instituto ECOAR para a Cidadania). Ressalta-se que os mesmos foram escolhidos por mim, a partir de considerações sobre a experiência na área e convergência com a proposta.

Outra característica do curso foi a intenção de realizá-lo presencialmente e à distância. Essa opção ocorreu por acreditar-se que os momentos presenciais seriam essenciais para a constituição da comunidade de aprendizagem, enquanto que nos momentos em que estivessem "distantes" os alunos teriam a possibilidade de "olhar" mais para o seu projeto de intervenção educacional. Compreendo que esses dois momentos devem ocorrer de modo relacionado, visto que o processo educativo alimenta-se da vivência dos estudantes nestas duas dimensões. Para a comunicação à distância elegeu-se a ferramenta eletrônica. Contudo, essa foi uma dimensão que apresentou uma série de falhas.

A avaliação da aprendizagem e do desempenho dos alunos ficou a critério dos professores que ministraram as disciplinas e da coordenação do curso, com base nas atividades desenvolvidas em sala de aula e também 
naquelas destinadas aos trabalhos com os agentes locais. Como produto final definiu-se um relatório do projeto de intervenção educacional desenvolvido; o caderno de campo/diário de bordo de cada aluno com a descrição e a análise de sua trajetória no curso; exposição fotográfica, artigo científico e/ou vídeo (Anexo A).

Em novembro de 1999 foi aberto, através do Diário Oficial do Estado da Bahia, o processo seletivo para as trinta e cinco vagas disponibilizadas no projeto do curso. A seleção ocorreu no dia 20 de dezembro, constando da análise do currículo e do questionário respondido pelos candidatos, contendo cinco questões referentes à: apresentação, área de atuação, disponibilidade de tempo para dedicar-se ao curso, motivação para a escolha do mesmo, e tema de interesse para o desenvolvimento do projeto.

Dos quarenta e três candidatos inscritos foram selecionados trinta e cinco. Contudo, cinco não efetivaram a matrícula, ocorrendo a convocação de outros para completar o número de vagas disponíveis. Por fim, nos primeiros dias de atividades do curso, uma das estudantes selecionadas (professora da UESB e mestre em Ciências Sociais) foi convidada para integrar o corpo docente, visto que possuía experiência na área e interesse em colaborar com o projeto.

Iniciaram o curso, portanto, trinta e quatro alunos, de formação e área de atuação bastante diversa, conforme visto anteriormente ${ }^{16}$ : biólogos(as), pedagogas, geógrafas, engenheiros agrônomos, químicos(as), licenciadas em letras, sociólogo, filósofa, licenciada em história.

É importante ressaltar que o número de vagas foi definido com base nas despesas geradas pelo curso e pela necessidade de o mesmo ser "auto sustentável", uma vez que a universidade não oferece recursos para o desenvolvimento dessas atividades. Nesse sentido, cada estudante arcou com o pagamento de doze mensalidades para custeá-lo.

\footnotetext{
${ }^{16}$ Vide p. 65-7, do capítulo anterior.
} 
Foram realizados sete encontros presenciais entre alunos, docentes e a coordenação do curso no período de fevereiro de 2000 a fevereiro de 2001. Esses encontros consistiram de aulas das disciplinas e de reuniões entre os grupos de alunos e a coordenação para avaliação e planejamento das ações dos projetos de intervenção educacional desenvolvidos nas comunidades, sendo distribuídos da seguinte maneira:

a) O primeiro encontro/módulo ocorreu entre os dias $26.02 \mathrm{e}$ 03.03.2000 e foram ministradas aulas das disciplinas Educação, Cidadania e Ação Coletiva; Cooperação e Extensão Universitária; e Educação Ambiental e Agenda 21 Local. O mesmo iniciou-se com a apresentação da proposta do curso, conforme Anexo 2, e discussão de questões administrativas. Ao final, os estudantes dividiram-se em sete grupos para a realização do projeto de intervenção educacional.

b) Nos período de 30.03 à 02.04.2000 ocorreram as atividades do segundo encontro/módulo, com aulas das disciplinas Educação Ambiental e Agenda 21 Local e Metodologia da Pesquisa Ação Participativa;

c) O encontro seguinte ocorreu entre os dias 27.04 e 03.05.2000, com atividades das disciplinas Pesquisa e Intervenção e Elaboração do Projeto;

d) O quarto encontro contou com aulas da disciplina Tópicos Especiais em Desenvolvimento Sustentável e ocorreu no período de 31.05 à 03.06.2000.

e) Durante o período de 24 à 29.09.2000 realizaram-se as atividades da disciplina Seminários, que consistiram na apresentação por parte dos estudantes do que havia sido realizado nos projetos de intervenção e no planejamento das etapas seguintes. Este encontro teve um caráter diferenciado, visto que era a oportunidade de reencontro dos estudantes após cerca de três meses de greve das universidades estaduais da Bahia, o que impossibilitou a continuidade das atividades como previsto inicialmente. Este momento, portanto, destinava-se à socialização dos projetos em desenvolvimento, ao planejamento das etapas seguintes e, além de tudo, ao 
esclarecimento sobre questões relacionadas à avaliação final e outras questões burocráticas.

f) No dia 26.10.2000 houve um seminário, com o intuito de apresentar e discutir os avanços relacionadas ao projeto de intervenção educacional em andamento após o encontro anterior; e

g) O último encontro ocorreu no período de 16 a 18.02.2001 e constou das apresentações dos resultados das intervenções ${ }^{17}$ realizadas (Anexo c), através de vídeos, exposições fotográficas e peças teatrais. Contou com a participação dos estudantes, alguns professores e integrantes dos grupos PAP formados nas comunidades.

Dos trinta e quatro alunos que iniciaram o curso quatro seis desistiram por diversos motivos - incompatibilidade com a atividade profissional, com os integrantes do grupo de trabalho e, ainda, com a proposta do curso. Quatro foram reprovados e vinte e cinco aprovados. As reprovações ocorreram pelo não cumprimento das atividades de disciplinas e, especificamente em dois casos, pela não entrega do artigo científico, solicitado pela coordenação e professores, aos integrantes de dois grupos que apresentaram relatórios das intervenções muito frágeis, não atendendo ao que foi acordado anteriormente.

${ }^{17}$ Anexo C. 


\subsection{Sobre o Curso de Especialização}

Conforme dito anteriormente, apresento a seguir alguns trechos selecionados dos documentos e transcritos das entrevistas, relacionando-os ao referencial teórico desse estudo. Optei por agrupá-los em três temas e ou categorias: i) percepção da proposta educativa, onde busco apresentar 0 entendimento que os estudantes têm do curso e as dificuldades e conflitos observados na tentativa de identificar aspectos que podem ter comprometido o processo de aprendizagem; e b) o impacto no cotidiano, visa identificar em que medida o curso promoveu - ou não - o incremento na potência de ação dos estudantes.

Considero oportuno, entretanto, apresentar algumas ponderações sobre os cadernos de campo dos/as estudantes, os quais deveriam constituir-se, segundo Gutiérrez e Prado (1999, p. 70), no "testemunho escrito, gráfico ou audiovisual do que se aprende a cada dia; é uma ajuda à memória dentro do processo de aprendizagem". Com essa perspectiva foi solicitado aos estudantes a adoção do referido caderno. Observei, contudo, que isso não efetivou-se na prática e, com exceção de cinco cadernos, os demais constituem-se em relatos burocráticos sobre o ocorrido nas aulas, relacionado quase que exclusivamente ao conteúdo trabalhado. Não houve uma análise mais cuidadosa sobre o processo, nem a expressão do processo de aprendizagem vivenciado.

\subsubsection{Percepção da proposta educativa}

$\mathrm{Na}$ perspectiva da educação ambiental que norteia esse estudo, educar significa criar condições para que o(a) educando(a) seja capaz de fazer uma leitura atenta da realidade social em que está inserido, de modo a se sentir compelido à participar ativamente nessa realidade, através da 
cooperação e do diálogo. Desse modo, o processo educativo deve indicar onde se quer chegar sem apresentar de antemão todos os passos que farão o caminho. Este percurso tem que ser construído gradualmente e pressupõe a valorização das incertezas - inerente aos tempos modernos, dos erros, dos problemas e das inseguranças. Eles são a matéria -prima do saber. Assim, como afirma o/a estudante:

"A vida acadêmica precisa resultar num processo permanente de construção do conhecimento, tendo em vista formas mais competentes e autônomas de atuação e intervenção na realidade. Para isso é necessário a reflexão e ação (teoria e prática) como instrumentos para a construção epistemólogica. Neste sentido, é preciso falar de uma educação não reprodutora, mas construtora de conhecimento e mediadora de saberes; uma educação que leve não só ao "aprender a aprender", mas também ao "saber pensar"; uma educação que esteja de fato comprometida com construção do sujeito autônomo, crítico e consequentemente cidadão. Procedendo assim, passa a ser o caminho para a construção do conhecimento; passa a ter uma função global na vida do sujeito porque intermedia positivamente na relação com o mundo e sua compreensão da realidade. E o conhecimento como processo e como aquisição inacabável necessita da reflexão crítica (algo puramente teórico) e da ação (como prática modificadora). Este foi, para mim, o principal desafio do curso de especialização "Educação para Sociedades Sustentáveis", que do lado de outros, explícitos no programa, rompem com o modelo de curso de pós-graduação praticado nas várias instituições universitárias" (E 28 , caderno de campo).

O depoimento acima demonstra o entendimento exato da proposta educativa que estava sendo implementada no curso. Contudo, representa 
uma exceção. A partir da leitura e análise dos cadernos de campo, em uma tentativa de identificar em que medida os/as estudantes apreenderam a proposta educativa, percebi que a maioria destes/as não havia ainda elaborado o significado do processo vivenciado.

Contudo, a leitura possibilitou-me re-fazer a trajetória do curso, a partir dos registros. Assim, considero interessante transcrever esse percurso para que os conflitos, as modificações ocorridas, as alegrias sejam visualizadas. Percebe-se que a cada encontro novas dúvidas e inquietações foram geradas, resultando, em muitos momentos, no imobilismo e na letargia. Isso pode ser atribuído ao conteúdo e à proposta pedagógica que representaram uma novidade para a maioria dos envolvidos, acostumados com atividades destinadas à "transmissão de conhecimentos".

"Fora a decepção de ter percebido que o curso não era o que havia imaginado, pois até o instante não foram ministradas as técnicas comprovadas cientificamente para solucionar o grave problema, estava preso a um romantismo sem igual. Mas sem soluções efetivas/práticas" (E 10, caderno de campo).

"A falta de diretividade leva a uma situação de confusão entre nós, o que pode causar até um estado de "letargia". Na própria execução dos trabalhos, alguns avançam velozmente, da forma como entendem ou como sempre fizeram, talvez sem levar muito em conta as considerações do curso. Outros, como o nosso grupo, ficam esperando por algo, que talvez não vá acontecer; esperando por uma metodologização mais clara, mais racionalista mesmo. Aprendemos dessa forma, nos acostumamos com isso. Fica difícil, muito difícil mesmo entender de outro jeito" (E 27, caderno de campo). 
Uma educação pautada na participação democrática deveria conduzir segundo Gutiérrez $(1988,86)$ "à educação auto-gestionária, o que constitui uma alternativa radical e, até certo ponto, totalizante, na medida em que supõe democracia, liberdade, participação, criatividade e compromisso político". De modo algum deve-se entender a não-diretividade como sinônimo de auto-gestão. Contudo, pelo que percebe-se na fala acima, o processo que partia do pressuposto da auto-gestão não foi compreendido em sua totalidade pelos/as estudantes.

Essencial ao processo auto-gestionário é a atuação interessada por parte do educador e um "deixar-se levar" pela dinâmica do grupo e pelo imponderável inerente a este processo. Atitudes de indiferença e falta de compromisso, por parte dos/as educadores/as e dos/as educandos/as comprometem irremediavelmente tal processo. Gutiérrez afirma, ainda, que para além do rompimento com o tipo de relações da educação tradicional a autogestão supõe a criação de uma rede de "comunicações própria que permita a cada participante a satisfação de descobrir-se a si mesmo em aut6entica comunicação com o outro e de sentir vivamente o encontro com o apoio do outro" (op.cit., p. 90). A fala abaixo pode ser vista a partir dessa compreensão:

"E no decorrer do processo não existe respostas prontas, a cada instante, a cada passo dado, a cada ida a comunidade nos deparamos com turbulências e não existia uma metodologia pronta, fomos construindo passo a passo. Assim, coube a mim e ao meu grupo buscar a dimensão pedagógica dos conflitos e resolver os problemas conforme iam surgindo. Perpassamos por um enorme exercício prático de inter/transdisciplinaridade quando na busca de soluções mergulhamos num processo de compreensão da complexidade das intervenções educacionais e das questões sócio-ambientais“ ( $E$ 8, caderno de campo). 
A transformação social requer educadores/as ambientais capazes de realizar o exercício exposto acima, tornando-se preparados para atuar na área ambiental, especialmente na formação de agentes locais, a partir de uma postura crítica, aberta e afetiva. A incorporação de novos valores e o "empoderamento" dos sujeitos representava a possibilidade do curso ser eficaz.

As estratégias para a implantação e implementação do curso basearam-se em três eixos, conforme dito no item anterior. Assim, através da pedagogia da práxis, representada pelos projetos de intervenção destinados à formação dos grupos PAP pretendia-se contribuir para a construção de conhecimentos e para potencializar as ações dos sujeitos.

"Na verdade, a estratégia é levar a comunidade a desenvolver o projeto, formando o grupo PAP. Por sua vez a utopia é feita por meio de uma ação pedagógica na qual podemos formar os disparadores, criando uma consciência para construir o futuro sócio-ambiental. Cabe ao grupo PAP, trabalhar essa relação Pesquisa Ação, ou Pesquisar na Ação, ou ainda pesquisar como vai se dar a consciência do desejo que é a teoria que fundamenta a interlocução - o poder de criar núcleos de universos de locução, o qual é uma forma de participação em que a abertura da fala vai dar o aumento da consciência emancipatória. Diante disso, faz-se mister a afirmação de que a PAP pretende abrir a fala, o desejo, a emancipação, o interesse pelo poder, enfim, criar uma cultura emancipatória" (E 28, caderno de campo).

"Ficou claro que o caminho (ou metodologia) seria o do conhecimento aplicado na solução de problemas, considerando uma tríade necessária e indissociável que é a da cultura, da técnica e ambiente. Neste sentido, seria necessário aproveitar as potencialidades, os 
valores, os saberes de cada um; haveria de se respeitar as diferenças culturais já que isso faz a diferença no gerenciamento dos grupos" (E 19, caderno de campo).

A proposta de formação dos grupos PAP pautou-se, também, na intenção de confrontá-los com a realidade vivida por milhões de pessoas a fim de despertar o desejo de interferir, no sentido de promover uma ação voltada à melhoria da qualidade de vida daquelas populações. A compreensão de que a "desigualdade é o problema "ambiental" mais importante do planeta", conforme afirma Beck (1999, p. 80) é imprescindível à uma ação mais politizada no interior da EA.

"Inicialmente o olhar diante do local foi de encantamento, pois ao observar o lado esquerdo vimos ruas calçadas, saneamento básico, escola, creche e posto médico, ao passo que, do lado direito, na Rua Heniqueta Prates (...) os moradores sobrevivem em estado de pobreza acentuada, visivelmente percebida através da quantidade de moradias e submoradias ali encontradas, precárias condições de higiene, falta de saneamento básico (águas servidas lançadas diretamente ao solo e esgoto ao céu aberto), tendo como agravante a deposição de resíduos sólidos nas valas de drenagem utilizadas como esgoto. (...) Ficamos tocados com a situação do lugar e, por isso, decidimos delimitá-lo como nossa área de estudo" (E 4, caderno de campo).

A partir do exposto acima, percebe-se a importância dos processos educativos desenvolverem nos/as educandos/as a noção de qualidade de vida e a importância de trabalhar pela qualidade da própria vida, assim como pela dos que não a têm. Herculano (2000, p. 237) propõe um conceito para qualidade de vida que deve nortear as ações dos referidos processos: 
"a soma das condições econômicas, ambientais, científico-culturais e políticas coletivamente construídas e postas à disposição dos indivíduos para que estes possam realizar suas potencialidades: inclui a acessibilidade à produção e ao consumo, aos meios para produzir cultura, ciência e arte, bem como pressupõe a existência de mecanismos de comunicação, de informação, de participação e de influência nos destinos coletivos, através da gestão territorial que assegure água e ar limpos, equipamentos coletivos urbanos, alimentos saudáveis e a disponibilidade de espaços naturais amenos urbanos, bem como da preservação de ecossistemas naturais".

A formação dos grupos PAP, possibilitaria a geração de conhecimentos a partir do estabelecimento de uma atitude crítica e reflexiva, que buscasse entender o processo, com suas causas e a sua dinâmica, a fim de interpretá-lo à luz das informações e ou teoria disponibilizadas, objetivando adequá-los a novas situações. Dessa maneira os/as estudantes e os agentes locais estariam aptos a agir na história, como dizia Paulo Freire (1996, 2000).

"A formação de um grupo de Pesquisa Ação Participativa (PAP) nesta comunidade significaria um espaço para a organização e participação, numa perspectiva de autonomia e emancipação e isso tenderia a acontecer a partir do levantamento e (re) conhecimento de seus reais problemas e da implementação de ações no sentido de solucioná-los. Ao mesmo tempo estaria se processando a construção (e produção) conjunta de conhecimento, na medida em que as informações estivessem sendo fomentadas; os saberes e as potencialidades individuais considerados e aproveitados. Conscientização, mobilização, ações e participação estariam sendo tomados como 
potências geradoras da compreensão das causas e dos efeitos da insustentabilidade social, econômica e ambiental e como instrumentos para a construção da autonomia e emancipação" (E 28, caderno de campo).

A partir do depoimento acima percebe-se que as idéias de participação, de autonomia e de emancipação que permearam todo o processo, foram compreendidas pelos/as estudantes e, na medida do possível, incorporadas à sua prática, conforme verifica-se na fala abaixo. Acreditava-se que a apreensão desses princípios e ou conceitos seria um caminho para o estabelecimento de ações que possibilitassem 0 enfrentamento dos problemas ambientais relacionados ao cotidiano das comunidades.

"possibilitou (...) suscitar ao alunado do grupo PAP que estava se formando a participação. Então conforme a teoria que nos foi dada e conforme a necessidade de se trabalhar conduzindo as comunidades no sentido que elas possam estar participando, que você possa tá induzindo essa comunidade a tá discutindo os seus problemas... de certa forma um dos conceitos básicos seria esse: a questão da solução de problemas e a participação dessa própria comunidade na solução desses problemas. Foi um dos conceitos básicos que o curso nos possibilitou (...) estar sempre nos policiando no sentido de não estar interferindo, dentro de seus conceitos, dentro de sua, como se diz, dentro da própria comunidade, dentro daquilo que às vezes a comunidade tem como correto e você às vezes (...) condiciona essa comunidade ao que você quer e foge do objetivo do próprio curso que é colocar a própria comunidade por si para solucionar os seus problema. Você possibilita a comunidade discutir os problemas e a 
própria comunidade dar soluções para seus problemas" (E 24, entrevista).

Contudo, a apreensão desses conceitos e ou princípios ocorreu de forma lenta, como vê-se abaixo:

"Ao refletir sobre a proposta do curso de formar agentes de sustentabilidade, que tivessem como características marcantes a autonomia, percebi que nós, os "detentores do conhecimento", os "messias", "os salvadores da pátria" comportava-mos como cozinheiros a espera de uma receita de bolo, a espera do conhecimento ruminado, regurgitado e repassado; a espera da velha fórmula mágica que daria a solução para tudo. Ai veio a pergunta, com o falar de autonomia e emancipação se nós nos comportávamos como viciados do sistema, dependentes de um conhecimento sedimentado? Foi então que percebi que a emancipação deveria começar por nós" (E 11, caderno de campo)

"Por receio, medo de errar, temor em romper com o arcabouço mental já estruturado, resultante de nossa educação tradicional e arcaica, baseada na submissão, não haviam, até aquele momento tomado iniciativa quanto à intervenção" (E 27, caderno de campo).

É interessante verificar como as estratégias e ou técnicas destinadas à formação dos grupos PAP foram entendidas pelos/as estudantes. As falas seguintes demonstram o sentido dado à técnica do olhar distraído:

"Retornamos ao município em 18/03/00 com intuito de fazermos um "olhar distraído", confesso que essa forma de pesquisa é excelente, mais a necessidade de nos policiar é constante, pois estamos mal 
habituados a questionamentos diretos e o exercício propõe a observação de maneira sutil, reaprendendo a ouvir o povo, perceber melhor o ambiente e todas as suas peculiaridades sem interferir, simplesmente observar" (E 2, caderno de campo).

"aprendemos a melhor observar o que nos entorna com um olhar que não considerei distraído, mas sim, crítico, pois passei a evidenciar o descaso com o tema como uma anormalidade e que não deveria fazer parte do nosso cotidiano a exclusão de seres humanos e as agressões ao ambiente que nos cerca, muito embora sempre nos chocasse, mas era sempre vista como obra do ocaso social, fruto da nossa impotencialidade e omissão dos governantes" (E 10, caderno de campo).

Daí percebe-se que o exercício realizado possibilitou que o mesmo olhasse o seu entorno sob uma outra ótica. Nesse sentido, coisas que muitas vezes passam despercebidas, são percebidas em sua verdadeira dimensão, desde que os sujeitos coloquem-se em um estado de aprendizagem constante.

Outra técnica utilizada foi a da oficina de futuro em que, segundo o/a estudante:

"são colocados os sonhos das pessoas, a nível pessoal e coletivo, (Árvore dos Sonhos), seus problemas e obstáculos (muro das lamentações), facilitando a visualização do problema ou problemas gerais mais acentuados chegando também aos meios para alcançar a(s) solução(ões) viáveis, os meios e os potenciais para a viabilização destes. Este método pode ser aplicado nos trabalhos a serem realizados a fim de se detectar as áreas a serem trabalhadas por cada grupo dentro de seu campo de atuação escolhido, salientando a 
importância básica de que é a própria comunidade que aponta seus problemas principais e suas potencialidades, culminando com o objetivo básico do curso que á a formação de grupo(s) PAP(S) para a obtenção e manutenção de uma melhor qualidade de vida" (E 11, caderno de campo).

Durante o curso foram utilizadas dinâmicas de grupo em que buscavase estimular o diálogo, a reflexão, o estabelecimento de vínculos que facilitassem a construção do conhecimento de cada um. Além disso serviam como exemplo do tipo de trabalho que poderiam realizar nas comunidades. Era a geração do saber com sabor, como fala Rubem Alves.

"Foram feitas diversas e interessantes dinâmicas de grupos que serviram para o exercício da integração e entrosamento entre o grupo e mexeram também com as afinidades entre pessoas, normal em qualquer grupo heterogêneo" (E 17, caderno de campo).

"o desenrolar do $1^{\circ}$ Módulo do curso foi fundamental para que eu me engajasse na sua proposta e me estimulasse a prosseguir. Extremamente dinâmico e enriquecedor tanto na abordagem dos conteúdos quanto na importância dada as relações humanas centradas nos ideais de respeito às individualidades, compreensão, companheirismo e cooperação, (...) teve como mola propulsora a realização de dinâmicas diversificadas e um apelo geral a conscientização e envolvimento frente à problemática ambiental" ( $E$ 19, caderno de campo).

"Na manhã de segunda-feira começou cada um construindo a sua história e o seu envolvimento com a questão educacional e ambiental, inclusive fotos importantes. Foi um momento extraordinário de volta às 
raízes, pois, cresci em um ambiente saudável, adorava viver no campo. Mas, também muito triste, porque não tinha nenhuma foto para registrar na minha história. É como se você não tivesse passado. Hoje em dia com meus filhos, não deixo passar nada, registro tudo de importante na vida deles. Alguns colegas fizeram comentário. Depois as histórias de cada um ficaram expostas na sala. Tenho certeza que todos que construíram a sua história fizeram uma viagem maravilhosa, porque tinha uma significação na vida de cada um" (E 3, caderno de campo).

Estas técnicas, eminentemente participativas, possibilitam debates e discussões que conduzem ao desvelamento da realidade local e a construção coletiva do conhecimento. A Agenda 21 do Pedaço constitui-se no planejamento participativo de ações visando a melhoria da realidade local.

"Para mim a formulação de uma agenda 21 local, simboliza não só o ideal de desenvolvimento sustentável, mas de uma sociedade justa e mais harmoniosa em suas relações sociais e entre estas e o seu ambiente no reconhecimento da preservação de toda a espécie de vida. A importância da elaboração das agendas 21 de "pedaços" é fundamental porque a partir delas é que realmente estaremos seguindo o princípio de pensar globalmente e agir localmente" (E 3, caderno de campo).

Participação no sentido defendido pelo curso refere-se ao fortalecimento dos indivíduos e dos coletivos para que tenham mais controle sobre as questões que interferem no seu cotidiano e possam interferir responsável e coletivamente para que ocorram, na sociedade, as transformações sonhadas. Isso implica em entender a construção de uma Agenda 21, assim como qualquer projeto coletivo, como um processo 
entremeado de conflitos e diferenças na medida em que compartilhamos nossos sonhos, nossas dúvidas. Há que se buscar constantemente exercitar a capacidade de diálogo e de tolerância para superação destes conflitos e diferenças.

Com o intuito de estabelecer a comunidade de aprendizagem e fortalecer os vínculos em todos os momentos do curso buscou-se a consolidação de uma rede de comunicação virtual, através da disponibilização da relação do correio eletrônico dos participantes professores, alunos e coordenação - a fim de constituir-se em um instrumento para o debate das questões de interesse do grupo, dúvidas surgidas a partir da leitura da bibliografia sugerida e disponibilizada, assim como o acompanhamento das ações desenvolvidas nos projetos de intervenção. Surpreendentemente, poucos alunos não possuíam endereço eletrônico, ficando um colega responsável pelo repasse das informações enquanto não cadastrassem um endereço com o auxílio do setor de informática da UESB. Contudo a comunicação eletrônica não se estabeleceu. Os meios utilizados para contato restringiram-se ao uso do telefone e de correspondências enviadas por correio.

O depoimento abaixo retrata o entendimento do que era a proposta de comunidade de aprendizagem do/a referido/a estudante:

"significou um espaço para discussão, troca de experiências, avaliação e reavaliação das ações. Nesse espaço foi possível acompanhar e comparar as experiências e proceder crítica e autocrítica em relação às intervenções, expor as dificuldades e sucessos, avaliar o nível de envolvimento de cada um; o compromisso, as iniciativas e a participação nos grupos. As avaliações feitas nessa oportunidade serviram para nortear o depois, para inquietar cada um no sentido de querer participar de forma mais efetiva. Os descasos em relação à proposta do curso e ao projeto do 
grupo, também puderam ser observados mas, se constituíram numa minoria. Foi possível acompanhar o processo de formação e construção de conhecimento de cada um, bem como o nível de compromisso e adesão" (E 28, caderno de campo).

Contudo, durante as entrevistas, percebi que essa foi uma dimensão que não foi bem compreendida. Osas entrevistados/as, em sua maioria, confundiam a comunidade de aprendizagem com a comunidade local, onde desenvolveram os projetos. Percebe-se, assim, que houve uma falha na comunicação por parte da equipe executora, que não conseguiram transmitir a compreensão que tinham sobre esse eixo.

Contudo, a partir do depoimento acima, percebe-se que os momentos presenciais foram muito ricos, ao promoverem o debate sobre a educação enquanto possibilidade de integrar o ser humano ao seu contexto, na medida em que proporcionaram a reflexão sobre a sua realidade e o compromisso com a sua transformação, além de promover criação de vínculos afetivos entre os/as participantes. Como diz Paulo Freire, através de uma perspectiva emancipadora de educação o ser humano chega a ser sujeito, podendo constituir-se e construir a sua própria história.

"Pude assim perceber que é preciso educar as pessoas para a vida através da tomada de consciência. A conscientização não se verifica em seres abstratos e no ar, mas nos homens concretos e em estruturas sociais, para que se compreenda que ela não pode permanecer em nível individual . (...) Como nos propomos ser educadores ambientais é bom lembrar que os processos de aprendizagem são contínuos e interativos" (E 28 , caderno de campo).

Um outro eixo referia-se à disponibilização de informações partindo do pressuposto de que não há uma informação única a ser trabalhada, mas de 
que existe uma multiplicidade de idéias e de conhecimentos que devem ser acessadas pelos alunos à medida que sintam necessidade. Foram abordados temas considerados, pela coordenação do curso, como importantes para a formação de um/uma educador/a ambiental, através das disciplinas, porém a intenção era a de que o contato com esses assuntos gerasse a curiosidade dos alunos e o entendimento de que a busca por novos conhecimentos acontece por toda a vida.

"Ao começarmos a discutir sobre os objetivos, problemas reais a serem enfrentados e sobre a estruturação e condução dos grupos PAP das comunidades escolhidas para o projeto de intervenção, o que já parecia definido no módulo anterior foi totalmente desestruturado. Todas as certezas que parecíamos ter sobre o projeto e o processo de intervenção transformaram-se em gás. As certezas viraram poeira, o medo de errar tomou conta da maioria das pessoas que se encontravam presentes. O pânico e a impotência da situação foram substantivos" (E 11, caderno de campo).

Dificuldades e conflitos surgiam a cada encontro ou a cada ida ao campo. As dificuldades maiores, observadas inicialmente, diziam respeito à pouca experiência e ou contato dos/as estudantes com os temas abordados. Muitos/as deles/as estavam afastados/as da vida acadêmica há muito tempo, acumulando-se os problemas relacionados à compreensão de uma realidade que mudou e muda de modo muito rápido. Desse modo, foram registrados divergências e conflitos relacionados à algumas disciplinas e alguns professores, assim como em relação à coordenação.

"A disciplina (...) nos deixou um pouco confusos e as dúvidas foram aumentando, pela falta de alinhamento filosófico que já tínhamos seguido com outros professores" (E 9, caderno de campo). 
A fala do/a estudante refere-se à disciplina Metodologia da PesquisaAção Participativa e ao posicionamento do/a professor/a sobre o desenrolar das atividades do grupo do qual o/a estudante acima fazia parte. Verificouse, a partir dos relatos, que no afã de contribuir para a solução dos problemas ambientais identificados nas comunidades ou por uma compreensão diferente, os estudantes, muitas vezes, não seguiam as orientações expressas nos encontros e suprimiam algumas etapas no processo de construção do grupo PAP e, conseqüente, implementação do projeto de intervenção.

Esse momento, especificamente, foi muito complicado, visto que alguns grupos não aceitaram as críticas feitas e estabeleceu-se uma situação bastante desagradável, com alguns/mas estudantes confrontando a posição da mencionada professora com a adotada pelos professores do encontro anterior.

"Foi um momento cheio de angústias, incertezas, insegurança e desmotivação. Ficamos preocupados como retornar ao município de Lafayete Coutinho e consertar o que tínhamos errado, segundo Raquel, a presença de dirigentes políticos no projeto iria prejudicar 0 andamento dos trabalhos que a comunidade poderia desenvolver $\mathrm{e}$ com isso achamos que ela estava meio fora da realidade pois pensávamos que sem buscar parcerias, os grupos PAPs não iriam alcançar seus objetivos" (E 2, caderno de campo).

Compreende-se que para que a ação transformadora aconteça é preciso a consolidação de uma "pedagogia da indignação e não da resignação" conforme enfatiza Freire (2000). Buscava-se, desse modo, através da atividade educativa estabelecer um espaço onde cada um pudesse expressar e partilhar a sua indignação com os problemas sociais, 
ambientais. E que, a partir daí, tivessem consciência do que se passa no contexto social e da necessidade de uma atuação efetiva para a sua superação.

“(...) muitos dos grupos ainda não haviam percebido que o importante era a tomada de consciência, ação, que, na maioria das vezes não importa "como nem o lugar e sim aonde se quer chegar". (E 11, caderno de campo)

Entendendo que "a tomada de consciência se completa na ação transformadora da realidade" (Graciani, 1999, p.55), tentou-se demonstrar que a construção do conhecimento só efetiva-se na medida em que, de posse de novas informações, passa-se a refletir criticamente, de maneira contextualizada e produzimos um novo conhecimento que visa a transformação do real.

Outra dificuldade presente nas falas refere-se aos conteúdos trabalhados. Os temas abordados nas disciplinas não eram conhecidos pela maioria dos alunos, como percebe-se dos depoimentos abaixo:

“(...) mas o nível dele estava muito alto e a gente às vezes na aula ficava viajando porque, nós não tínhamos como acompanhar o raciocínio dele por falta de pré-requisito. Não foi nem falha dele, foi falha nossa. Nós não tínhamos pré-requisito pra poder estar assistindo a disciplina. Então, muita coisa (...) ficou perdida no espaço. Muita coisa ficou, mas muita coisa passou por falta de pré-requisito" (E 16, entrevista)

Assim como esse/a estudante, outros/as ressaltam que o maior problema do curso foi o despreparo dos alunos para enfrentar as discussões 
travadas em sala de aula e compreender os aspectos inerentes ao processo. É interessante observar que não atribuem essa dificuldade à proposta do curso, aos novos conceitos.

“(...) mas foi justamente falta de preparo da gente, não é questão do curso $\mathrm{O}$ que eu gostei do curso, apesar da gente ter tido dificuldades: os professores, no caso todos os professores nos deram fonte bibliográfica e o objetivo do curso acho que é isso: não é nos ensinar, passar tudo pronto pra gente. $\mathrm{E}$ eu acho que o objetivo maior foi esse. Eles nos deram condições de procurar essas fontes e a dificuldade que eu tive no Sarmento, ele me deu fonte para eu poder tirar (...) Então eu achei e acho que apesar das dificuldades houve a resolução. Porque não é que todo mundo sai pronto, o curso não é isso, é sair pronto. Ninguém sai. E sim nos orientar pra que se prepare cada dia mais" (E 23, caderno de campo).

A ansiedade gerada por um processo que está sempre refazendo-se e que não apresenta respostas prontas de como alcançar o objetivo definido inicialmente, aliada a uma proposta que representava uma novidade absoluta em termos de conceitos, abordagem e na própria linguagem dos professores e da coordenação gerou, em muitos momentos, um desgaste na relação destes com os/as estudantes.

À medida que o curso avançava surgiam problemas de diversas ordens, como observa-se na fala desse aluno.

“(...) vale salientar o incidente que tivemos nesse instante: Estávamos todos amplamente desinformados acerca de vários assuntos concernentes ao andamento do curso, tais como próximo módulo (soubemos que Marcos Ferreira daria aula no próximo módulo e tivera solicitado o fichamento de diversos textos para serem entregues 
já no início, o que coincidiu com os fichamentos dos textos solicitados pela Profa ${ }^{(}(.$.$) - só que essa informação não foi oficial); questionamos$ o porque do fichamento dos textos solicitados pela professora Sônia já que tínhamos discutido todos os textos em sala de aula; o que aconteceria com os alunos que faltaram alguns dias de aula em alguns módulos, que em particular me insiro no III módulo... Chegamos então a conclusão que era necessário eleger um líder da turma para nos representar e tentar sanar nossos questionamentos, fato que não teve êxito uma vez que a escolhida não aceitou alegando não está a vontade para representar a turma, ou melhor, não concordar com tais questionamentos" (E 19, caderno de campo).

Esse depoimento requer algumas considerações. Primeiro referente a desinformação citada pelo aluno, uma vez que todos receberam no primeiro dia de aula um material apresentando a proposta do curso, constando de itens como: estrutura dos módulos, formas de avaliação - final e a indicação de que a avaliação por disciplina cabia ao professor -, calendário das aulas, dentre outras. Essas datas eram reforçadas a cada final de módulo pela coordenação - secretário ou coordenadora, e apenas a data do segundo módulo foi alterada até que ocorreu a greve dos docentes, no segundo semestre.

Com relação a solicitação do fichamento e da disponibilização do material bibliográfico a serem utilizados nas aulas percebe-se outro equívoco, pois os dois docentes citados participaram de atividades referentes ao primeiro módulo de aulas e apresentaram de forma rápida o que seria abordado em suas disciplinas e como seria trabalhado - leitura e fichamento para apresentação em forma de seminário-, indicando que a bibliografia referente aos assuntos estaria disponibilizada no setor de reprografia no módulo que os antecedesse - um mês antes. E assim aconteceu, tendo sido avisados pela coordenação quando estavam disponíveis. 
Questões como essas, e muitas outras, causaram um desgaste não só na relação entre a coordenação, os/as estudantes e os/as professores/as, mas também na imagem do curso junto à comunidade acadêmica, uma vez que percebia-se por parte de muitos alunos o entendimento do processo proposto como se tudo fosse permitido e de que não haveriam cobranças. Tal entendimento foi disseminado na universidade causando problemas à coordenação, inclusive no interior do próprio departamento, que naquele momento oferecia um outro curso de especialização havendo uma série de procedimentos regimentais que deveriam nortear a ação dos mesmos.

Nos módulos anteriores, especialmente no terceiro módulo, em que discutiram-se questões relacionadas à elaboração do projeto de intervenção (complexidade, transições paradigmáticas, ciência pós-moderna) ocorrendo a solicitação da apresentação de um ante-projeto para avaliação percebeu-se a falta de repertório destes, retratando a falta de leitura do material já disponibilizado e a não assimilação do processo.

A intencão ao apresentar essas considerações não caminha no sentido de defesa da coordenação ou de quaisquer docentes, mas por achar necessário a visualização exata dos acontecimentos. Em relação à solicitação dos fichamentos por parte da professora mencionada acima contatou-se apenas três registros que entendiam de forma negativa a realização da atividade.

Os/as demais não registraram o ocorrido ou posicionaram-se favoráveis à realização dos fichamentos, como vê-se abaixo:

"Apesar do avanço conquistado, a cultura tradicional, centrada na distorção da práxis foi reverenciada neste módulo, em um caso isolado de um docente, pela imposição da anti-democracia. Não obstante o respeito e o diálogo serem inerentes e atávicos no grupo PAP original do curso" (E 17, caderno de campo). 
"Olha só, até tava discutindo esses dias atrás com nosso grupo, Márcia e Rita, que houve assim uma, um alvoroço com a discussão de Sônia quando mandou fichar aqueles textos e aí estava dizendo: a base do curso foi aqueles textos de Sônia e a felicidade nossa foi ter fichado aqueles textos porque "Um discurso para as Ciências", "O nosso futuro comum", aquilo diz tudo. Que você tem que trabalhar com o senso comum, você esta buscando a própria comunidade, você esta buscando a própria comunidade. Você estar buscando o saber popular, o saber né, você sabe ensinar, eu sei ensinar, é um tipo de saber. E o saber popular o que acontece: às vezes você acha eu sei, você não sabe e ele tem o seu saber que é diferente do meu, mas se eu for trocar uma opinião o cara : ha! Eu sei!. E isso foi através do saber popular que foi sendo passado de pai pra filho. E também é importante "As revoluções científicas" pelas questões dos paradigmas" (E 24, entrevista).

"Um dos melhores, minha participação nas aulas aumentou à medida que conseguia ler mais e dominar os assuntos propostos. (...) Prof. (...), por sua vez, foi muito feliz ao abordar sobre o mesmo assunto, onde foi nos passada uma tarefa de fichar alguns textos, 5 ou 6 , não lembro, mas foi ótimo. A leitura fez-me entender muitas falas anteriores" (E 9, caderno de campo).

Os últimos depoimentos ressaltam a compreensão de que a proposta da práxis pedagógica não se constitui sem a necessária reflexão sobre os acontecimentos e o contexto, e isso prescinde de aporte teórico, como enfatiza Graciani (1999, p.84):

"a proposta da práxis implica (...) três processos fundamentais de apropriação: a do conhecimento universal já acumulado 
historicamente pela civilização sobre a realidade do mundo, da sociedade e do ser humano e de si próprio; a apropriação das faculdades e instrumentos teóricos adequados para criticá-lo e superálo, para ir além deles no plano da percepção e da compreensão; e, finalmente, a apropriação das faculdades e instrumentos práticos adequados para reconstruir, recriar e transformar a história, a realidade e a sociedade".

Essas questões, aliadas à não sintonia com a proposta do curso por parte de alguns, resultaram no afastamento dos professores da própria universidade dos/as estudantes, ocasionando um outro problema referente à orientação dos trabalhos dos mesmos - no campo e nos momentos de estudo teórico que ficaram a cargo da coordenação do curso. Em conseqüência disso acrescenta-se à lista dos problemas e das dificuldades enfrentadas a orientação ineficiente e insuficiente para atender às demandas dos alunos. Problemas infra-estruturais também foram uma constante resultando em novos conflitos entre a coordenação e os alunos.

“(...) procuramos avaliar o que deu certo no desenrolar do curso, segundo a ótica dos alunos e da coordenação. Em alguns aspectos houve concordância; em outros divergência. Algumas dificuldades devem ser destacadas como por exemplo: a incompatibilidade nas comunicações no que se refere ao estudo a distância e a ausência de orientador para o trabalho, o que nos causou transtorno" (E 19 caderno de campo).

"Uma atividade democrática e enriquecedora para nós nesta etapa, foi a de apontar os pontos positivos (ou o que deu certo) e os negativos (ou que precisam ser melhorados) no decorrer do curso. Conscientes de que a avaliação é indispensável para a continuidade e 
planejamento das atividades futuras desse processo, as equipes, em sua maioria apontaram como aspectos positivos as dinâmicas, o alto nível da qualidade das informações e a conscientização geral e envolvimento dos alunos na problemática sócio-ambiental. Os negativos apontados na época e que até não melhoraram ainda foram: coordenação insuficiente para atendimento fora dos períodos letivos dos módulos e ausência de contato entre as equipes para troca de experiências" (E 1, caderno de campo).

Em todo processo educacional a avaliação constitui-se em um outro problema a ser administrado e no presente caso não foi diferente. As incertezas, as dificuldades inerentes ao novo criaram um clima de insegurança muito grande que resultavam em uma confusão generalizada quando falava-se dos critérios avaliativos das disciplinas e do curso como um todo.

Por ser um processo em construção buscava-se avaliar constantemente "o que deu certo" e o "que precisava melhorar" no curso, numa perspectiva de correção das falhas e aprimoramento.

O que deu certo:a) dinâmicas; b) estudo do meio; c) conteúdos; d) contato com a comunidade; e) oficina de futuro; f) metodologia dos professores; g) integração na comunidade e h) conscientização da turma. (cadernos de campo)

Percebe-se, a partir do exposto acima, que a proposta do curso, apesar das dificuldades, foi bem aceita pelos alunos que, em sua maioria, não havia tido contato com idéias, conceitos e metodologia que embasavam a proposta.

O que precisava melhorar: a) comunicação entre alunos, entre alunos e professores e entre alunos e coordenação; b) integração do grupo; c) calendário do curso; d) clareza na metodologia para os trabalhos na comunidade; e) ausência de orientadores para os trabalhos; f) referências 
bibliográficas; g) embasamento teórico; h) material gráfico e i) infra-estrutura da universidade. (cadernos de campo)

"Portanto apesar dos acertos e erros durante o curso, o resultado a que chegamos é realmente muito gratificante, pois contribuímos para a formação de agentes multiplicadores e esperamos que eles sejam capazes de manter a autonomia" (E 7, caderno de campo)

Contudo, apesar dessas dificuldades, observa-se por esta fala que os/as estudantes avaliam o curso como sendo um processo educativo rico e, nesse sentido, representa uma alternativa para a constituição de outra sociedade, mais igualitária, justa, solidária e feliz.

\subsection{O Impacto no Cotidiano}

Nos relatos dos/as estudantes entrevistados percebe-se que ocorreram mudanças no seu dia-a-dia, seja na esfera familiar, seja no âmbito profissional que relacionam-se ao curso de especialização implementado. Em níveis diferenciados verifica-se que houve mudança no comportamento e nas atitudes em relação às suas atividades profissionais, o modo de gerir o espaço doméstico e a visão diferenciada sobre os problemas sócioambientais locais.

"Desde em casa com meus familiares, questão de hábitos na alimentação, nas escolhas de alguns objetos dentro de casa, vasilhames de água, essas coisas. Tudo mudou muito em $\mathrm{mim}$ e também em relação a minha vida profissional. (...) Eu sempre ensinava ciências e eu não me importava muito com isso. Tinha essa parte de educação ambiental nos livros de ciências e eu sempre 
falava, mas de maneira assim obrigatória né, como realmente a programação manda. Mas nesse ano de 2001 eu ensinei biologia e nós tivemos o planejamento e elas ficavam: na primeira unidade citologia, na $2^{\mathrm{a}}$ os animais e então como já tinha esse curso, falei pessoal na $4^{a}$ unidade vamos fazer um apanhado disso tudo, estudando o ambiente em si, o valor que isso tudo tem prá gente, né, a começar pela célula e ai a gente fez um trabalho assim e foi muito gratificante. Então, prá mim foi muito útil, enriqueceu muito justamente prá mim ter essa bagagem, essa firmeza de assumir isso. E sendo à noite o pessoal geralmente faz um trabalho muito pobre e eu com esse curso me capacitei mais de fazer, trabalhar melhor com eles " $E$ 23, entrevista)

"Tanto é que no dia-a-dia você é capaz de ações que nos leva a perceber a grande importância que teve todo aquele conhecimento que foi desenvolvido durante o decorrer do curso, mediante a facilidade que a gente resolve e supera esses problemas que diariamente a gente encontra, principalmente no meio do convívio do trabalho né. Esses problemas, já que eu trabalho com fiscalização na área de saúde e na área ambiental também, no qual a gente nunca pode deixar de lado o sócio-econômico-político das coisas, e tentando buscar uma visão é, digamos assim, no contexto da vigilância sanitária, no contexto da saúde pública, no contexto do meio ambiente, de modo que a gente, ao mesmo tempo que fiscaliza, que cobra, que às vezes chega até a impor alguma coisa, a gente consegue mediante o que a gente aprendeu né, não impor tanto e tentar achar uma alternativa qualquer, resolver a situação" ( $E$ 5, entrevista). 
Os depoimentos deixam transparecer que as mudanças ocorridas advém da vivência no curso. Que a liberdade de escolha do caminho a seguir para a formação dos grupos PAP nas comunidades, na medida em que não indicava os passos, causou muitas inseguranças e angústias, mas proporcionou o fortalecimento das pessoas, resgatou os seus sonhos e desejos e os compeliu à ação.

"A virtude dele foi dar justamente a nós essa liberdade de escolha. Eu achei isso fantástico. A capacidade que vocês deram à gente de criar, né, deixando a gente livre para poder trabalhar, sem uma metodologia definida. Foi muito bom porque nós ficamos soltos, mas ao mesmo tempo buscando caminhar, sabe? Então esse prá mim foi fantástico. Você construir, você construir uma metodologia né, saindo do nada. Primeiro porque a gente tava conhecendo coisas novas. Ninguém do grupo tinha conhecimento do que era realmente educação ambiental e nós fomos construindo isso junto com o aluno. Caindo e levantando, caindo e levantando e nós fomos construindo. Então eu achei que a virtude do curso foi essa: dar a nós o direito de escolher. Mas ao mesmo tempo gerou uma insegurança muito grande, porque você sabe que tudo o que é solto gera medo e o que causa medo às vezes afasta as pessoas, né. As pessoas ficam com medo: eu não sei por onde caminhar, eu não sei por onde seguir. Meu Deus, será que eu tô certo? Aí foge, fica um tempo isolado, depois volta de novo. Então isso aconteceu muito no meu grupo. Porque não tinha uma metodologia. Mas ao mesmo tempo que deu medo foi uma coisa maravilhosa. Houve essa virtude fantástica do desafio. Vá, vá e faça, né. Que isso dá muito medo na gente. A gente tá acostumado, foi educado prá ser conduzido, né" (E 16, entrevista). 
Esse depoimento permite refletir sobre outro aspecto que caracterizou - curso: buscava-se que os/as estudantes deflagrassem processos participativos potencializadores da ação individual e coletiva na medida em que promovessem a autonomia e a emancipação dos grupos. Ou seja, eles deveriam colaborar para o incremento da autonomia e da emancipação dessas pessoas, na medida em que também se constituiam em sujeitos autônomos e emancipados. Verifica-se aí o papel da educação de possibilitar a auto-criação do sujeito.

"Porque o curso foi todo voltado para que a gente formasse pessoas autônomas e eu durante todo o curso eu procurei buscar essa autonomia" (E 16, entrevista).

Essa fala denota, também, a necessidade sentida pelos alunos de decodificar e incorporar o que significa a autonomia. Isso fica claro quando acompanha-se o relato do/a estudante:

"Eu achei que depois que o curso cessou um pouquinho que eu deveria deixar Rômulo caminhar sozinho, e os alunos lá do PAP caminhar só e eu não fui mais lá, né. $E$ depois eu fiquei me perguntando, eu tive uma conversa com Rômulo e disse: Mas eu falhei, porque nós sabemos que na realidade o ser humano ainda não tá preparado para caminhar só. Essa autonomia é uma conquista, mas é uma conquista que demora um pouco. Ela não é imediata. Também eu falhei no momento que eu achei que o aluno já tinha essa autonomia e não fui consultá-lo, não fui em momento algum falar com eles, não me envolvi nas atividades, entende? Eu me afastei completamente. Então eu acho que isso não ficou muito definido na minha cabeça a questão da autonomia. O que é ser realmente autônomo? É caminhar sozinho, sem ninguém? Porque a todo 
momento a gente precisa, se nós vivemos em sociedade nós precisamos desse grupo, nós precisamos da opinião do outro, nós precisamos ouvir o outro, nós precisamos consultar o outro porque a visão de mundo é completamente diferente" (E 16, entrevista).

Percebe-se que as inquietações geradas a partir do curso ainda são muitas. Entretanto, caminham no sentido de busca da consolidação de uma prática que recoloque a importância do estabelecimento de vínculos, de espaços de diálogo, de redes de apoio e solidariedade no cenário atual.

Ao mesmo tempo percebe-se o incremento na auto-estima desses alunos que passaram a sentir-se capazes de apresentar propostas novas no local de trabalho, de criar outros grupos de convivência em uma perspectiva de autonomia e emancipação. Pode-se dizer que isto constitui-se na forma de compromisso que Freire chama engajamento, que ocorre na medida em que o indivíduo descobre-se e lança-se conscientemente na transformação do real. Alguns relatos denotam a angústia gerada a partir da constatação da existência, no seu cotidiano profissional, de condições contrárias ao que apreenderam e, mais do que isso, da impossibilidade de uma modificação efetiva a curto prazo dessa situação. Essa situação revela a emergência de uma postura crítica, questionadora e que, na medida do possível, busca subverter a ordem estabelecida.

“(...) ultimamente vivo em conflito muito grande na prática profissional. (...) buscar algumas coisa sem deixar de mão a sustentabilidade, sem deixar de mão a saúde, a cultura. É você saber correlacionar tudo isso e a dificuldade que você tem em resolver essas coisas mediante toda uma sociedade, toda uma estrutura já formada, e você ter que obedecer algumas regras que não é bem o que você gostaria de seguir. E é um pouco angustiante às vezes quando você tem que tomar algumas atitudes que você não gostaria de tomar. (...)ter que 
impor alguma coisa que você gostaria de não impor, que você gostaria de educar (...) em se tratando de fiscalização, que é a minha prática atual, a gente às vezes não educa. A gente educa depois que a gente atua ou autua. A gente primeiro dá uma ferroada e depois a gente vai e passa a mão e acalenteia. Primeiro a gente age e depois você tenta, com a ação, fazer com que o indivíduo acabe por entender alguma coisa. Mas, geralmente quando a pessoa sofre algum tipo de ação, marca mas volta a fazer de novo alguma coisa. A gente vê muito isso! $\mathrm{Na}$ área que eu trabalho com meio ambiente(...) fiscalização, de um modo geral, a gente vê muito isso: você fala, a pessoa vai lá e você fala, fala, fala, e no dia que você não fala o cara volta a fazer tudo de novo. Então ele não assimilou coisa nenhuma que você fez. Não passou sensibilidade nenhuma pra ele..." (E 5, entrevista).

Indica, também, que a apropriação de novos conceitos, de novas concepções, de novos valores configuram no incremento da potência de ação dos sujeitos, conduzindo ao enfrentamento das situações que consideram em desacordo com os pressupostos de uma atuação que promova a consolidação de uma cultura emancipatória na sociedade. Isso implica não só na constatação do problemas, mas na adoção de iniciativas que os superem.

“(...) a gente tá com um projeto educativo em todas as escolas, um projeto que inclusive a gente inseriu. A gente fez esse ano 100 aulas educativas nas escolas todas, todas as escolas de Jequié e em todos os turnos e a gente distribuiu materiais, falando sobre educação, saúde e meio ambiente e também passando algumas noções de meio ambiente, cidadania. Essas discussões que talvez lá no futuro essas pessoas, principalmente as crianças, que a gente trabalha muito com crianças, não venha a sentir... pra que a prática deles no futuro seja 
diferente da dos pais hoje né. (...) Quando vai dar aulas, a gente dá palestras em todas as escolas, qualquer buraco a gente vai, a gente mostra algumas coisa e aí a criança fala: Ah! Meu pai faz isso! Meu pai faz aquilo! E a gente educa a criança pra ela tentar educar o pai em casa. E a gente sabe que não vai conseguir, mas fica naquela criança e a gente espera (..) Esse projeto é anual e às vezes a gente vai à escola no ano seguinte e encontra aquela criança em outra série e a gente fala alguma coisa e ela lembra daquilo que a gente disse o ano passado, a gente vê que ela não esqueceu. Eu acho que é por aí que a gente deve seguir. A gente pegar aquilo que aprendeu, aquelas noções que a gente teve e tentar aplicar isso e tentar passar. Não querer que o pessoal incorpore como a gente incorporou aqui. Porque a gente já buscou o curso porque tinha um certo sentimento, queria trabalhar com isso e não dá prá querer que as pessoas incorporem isso também, de um dia pro outro e trabalhe esses conceitos. A gente tem que fazer, eu acho, que se você quiser ter alguma esperança no futuro já é um pensamento até, não sei se você educando a criança você vai ver ele no futuro aplicando alguma coisa desse tipo. eles modifiquem o modo de vida deles lá e modifique pra melhor na verdade, da maneira como ele acha que tem que ser modificado. É isso aí" (E 5, entrevista).

Os relatos demonstram que, através do curso, foi promovido um processo de transformação na forma de ver o mundo pelos/as estudantes. Em contato com situações que não faziam parte do seu cotidiano e o convívio com pessoas que sobrevivem em condições adversas desemprego, submoradias, inexistência de esgotamento sanitário - gerou emoções negativas como o mal-estar, mas também o surgimento de sentimentos de solidariedade, vontade de ajudar a melhorar. 
"(...) quando a gente trabalha com um lugar, uma comunidade carente a gente acaba incorporando, acaba sentindo um pouco na pele o que o pessoal passa e acaba tentando, e acho que a gente até fugiu um pouco com a proposta do curso né. A gente acabou sendo, como diz o professor, paternalista e tentando de alguma forma é, não deixar o pessoal mais... acabou fazendo por eles na verdade, algumas coisas e fugiu um pouco da proposta do curso que é você dar a idéia, você induzir o pessoal a buscar suas coisas, deixar sua idéias. A gente viu que teve que dar um empurrão mesmo pro pessoal começar a andar. Talvez tenha sido um ponto negativo do nosso trabalho né. (...) talvez se a gente trabalhasse durante muito tempo com eles e ainda que um ou dois da comunidade acabasse por incorporar o sentimento, a sensibilidade de buscar alguma coisa e esses pudessem se multiplicar em outros e outros e o trabalho pudesse fluir ao longo de vários anos. Mas num curto espaço de tempo não foi tão fluente não" ( $E$, entrevista)

Nesse relato percebe-se, ainda, o entendimento da importância de trabalhos coletivos na busca de soluções para os problemas das comunidades e na mobilização para colocá-las em prática a partir das suas potencialidades. Indica também a compreensão de que no decorrer da sua intervenção educacional houve a opção por um processo educacional que se contrapõe ao que preconizava o curso. Entretanto ao reconhecer esse fato, assumindo o porquê da opção, denota que, embora houvesse assimilado a proposta do curso, não se acreditava na consecução dos seus objetivos seguindo aquele caminho e por um sentimento de responsabilidade por estar criando na comunidade sentimento de esperança na melhoria da qualidade de vida, nesse caso através de apresentação de alternativas ao desemprego. 
“(...) o nosso trabalho foi numa comunidade onde tinha pessoas super carentes né e a gente não poderia simplesmente intervir, tentar ajudar de alguma forma e depois, sei lá, tipo se não der certo largar pra lá e partir pra outro objeto de estudo. Sei lá, não é assim quando se trabalha com pessoas. Então a gente ficou muito preocupado com o pouco período de tempo que a gente tinha, o pouco espaço de tempo e a nossa disposição também, que a gente trabalha e tal, em desenvolver alguma coisa que pudesse ajudar o pessoal, que pudesse fazer eles buscar alguma coisa, que pudesse despertá-los pra alguma coisa. Eu acho que quando você trabalha como formador de idéias não é uma coisa fácil, que você vai lá e manipula. Quando você manipula uma coisa de laboratório, é diferente e foi essa nossa preocupação, nossa dificuldade maior em não saber ao certo qual seria o resultado que a gente ia obter e se o resultado seria o que ia agradar a comunidade, ia resolver o problema da comunidade. A gente foi tentando acertar em uma situação que a gente não poderia errar" (E 5, entrevista).

Todas as falas ressaltam, entretanto, o sentimento de tristeza e decepção por não haver se consolidado efetivamente relações de afetividade e companheirismo no conjunto dos/as estudantes, restringindo-se a uma relação mais próxima entre os integrantes de um mesmo grupo.

"Nós nos falamos "Oi. Tudo bom?" Mas não existe nenhum elo de ligação, eu só tenho elo de ligação com o meu grupo. E os outros grupos?" (E 16, entrevista)

"Eu acho que a integração entre nós, eu creio que houve. Agora essa questão de integração ... No final do curso perdeu um pouco o sentido porque acabou cada um zelando do seu trabalho e do seu projeto e 
tal, deixando um pouco de lado. Agora, durante as disciplina que foi discutida nos módulos e nos encontros houve integração sim. Não tanto quanto gostaria que existisse, tanto que aconteceu com a maioria né. Até porque, depois do curso a gente tem contato com poucos colegas e sabendo que estes tão atuando também, desenvolvendo o que foi aprendido né, desenvolvendo algumas coisa que foi relacionada aqui no curso" (E 24, entrevista).

Mesmo assim, percebe-se o estabelecimento de uma rede de apoio que proporciona a cada um sentir-se mais seguro no seu campo de ação e potencializa a realização de diferentes ações vinculadas à temática socioambiental.

A mensagem mais contundente dos relatos refere-se a aprendizagem adquirida através da participação nas atividades do curso, da convivência com as pessoas dos grupos PAP, permeada de afetos e emoções que resultaram em mudanças significativas na sua vida cotidiana.

"Eu não sou mais a mesma a partir do momento que eu passei pelo curso e aprendi a ver o mundo de forma diferente. Claro que teve! Eu não sou a mesma que entrou aqui. Eu não tenho o mesmo olhar. Eu não tenho mais aquele sentimento de indiferença. Eu me toco e fico pensando de que forma eu posso contribuir pra transformar aquela realidade. Então, só o fato de parar pra refletir e tá buscando, nem que seja mentalmente, porque eu acho que até a forma da gente pensar já contribui pra o planeta mudar. Eu acho que isso já tem um significado muito grande. A minha forma de pensar, minha filha, mudou completamente. O meu olhar, o meu sentir, mudou. Até pras minhas filhas, meu marido, meu pequeno pedacinho na minha casa já mudou muita coisa. Eu faço esse meu trabalho como formiguinha. Acho que a gente não tem que ser muito pretensiosa mesmo. A gente deve seguir 
o exemplo da formiguinha e onde a gente chegar a gente pode lançar a semente, então por que a gente tem que ter pressa?" (E 16, entrevista)

"As mudanças por as quais a gente passa faz ver o mundo de outra forma. Os conceitos que a gente tinha, os conceitos formados a respeito de certas coisa passa a mudar a partir das aula do curso, da vivência também nossa em campo. As mudanças são imensas. Nem pode dizer nunca que saiu do jeito que entrou porque foram mudanças totais" (E 2, entrevista).

Dessa fala depreende-se o nível de transformação que pode ocorrer quando as pessoas se permitem sonhar e idealizar e, mais que isso, se entregam ao desafio de construir uma outra realidade. $O$ aporte teórico somado às experiências vividas e a sua ressignificação converte-se em potência de ação, conforme ensina Espinosa.

“(..) uma das grandes virtudes desse curso que eu achei é um curso que incentiva a gente a sonhar. Sonhar com um mundo melhor, sonhar com mudanças, com transformações e sonhar não só a título de ficar, a título de pensamento, a título de utopia, sonhar prá buscar realizar né. O sonho caminhando junto com a possibilidade da realização. Essa realização que seria através de tudo o que a gente produziu no curso e que vem surtindo efeitos" (E 2, entrevista).

A alegria e a valorização dos momentos vividos e dos resultados das intervenções nas comunidades estão presentes em todos os depoimentos. É a visualização da concretização de um sonho resultado de medos e incertezas, por isso cheio de sentidos e significados. 
“... no final, no último dia, eu nem consegui dormir de ver todos os projetos realizados, as apresentações com falhas ou não. Que pra mim, ao meu ver, nem teve falha. Cada um mostrou. As falas foram tão lindas. Mas quando eu vi as apresentações no último dia do seminário com o pessoal de Aiquara, do desfile das roupas recicladas de papel, os depoimentos, no caso das duas escolas que tiveram depoimento na fita, né, as dramatizações. Então isso foi muito gratificante. Eu achei maravilhoso isso daí e eu senti que realmente no final eu esperei o curso e acertei nele. Fiquei muito realizada. Foi um curso assim que apesar de ser um pouco estressante, porque foi né, durante $\mathrm{o}$ ano a gente fazia ele mas tinha outras atividades, eu sou casada e tenho filhos e tal e trabalhando 40 horas... Mas no final foi tipo assim um anti-estresse, foi relaxante aquele final, a gente vê que a gente conseguiu. Mesmo os que não conseguiram, mas só de ter tentado né, mostrado um pouquinho. Acho que foi muito bom o curso, é uma qualidade muito grande. Eu achei ótimo" (E 23, entrevista).

"Porque eu aprendi que as coisas não vem de imediato, tudo é construção. E aí, na minha cabeça a coisa continua ainda bem latente. Cada vez que eu assisto a fita eu me emociono, eu choro. Porque ainda continua assim bem dentro de mim. Todas as vezes que eu vejo as falas das meninas aí eu choro. Então, ainda existe esse grande desafio dentro de mim" (E 16, entrevista). 


\title{
5 CONSIDERAÇÕES FINAIS
}

\author{
"Como para toda criatividade, a característica que \\ nos ocupa é ser eminentemente polissêmica e, \\ em consequência, passível de múltiplas \\ interpretações. Em resumo, este livro pode dar, \\ também, ocasião a leituras plurais. Deixo agora \\ que cada um festeje à vontade, no próprio texto \\ ou ao acaso das notas que lhe servem de \\ suporte. Esperando que isso possa ajudá-lo a \\ compreender o que pretende mostrar esta obra, a \\ saber a infindável e a inesgotável fecundidade de \\ toda socialidade".
}

Michel Maffesoli

\subsection{Os desafios para pensar a formação de educadores ambientais e o incremento da potência de ação.}

Com essa pesquisa, construída e reconstruída ao longo do percurso, não pretendo traçar um rol de recomendações sobre a implementação de processos educativos pautados na Educação Ambiental. Tampouco, apresentar conclusões definitivas sobre o processo analisado.

Concordando com Maffesoli (1996), reconheço que a interpretação que trago aqui é uma dentre as várias que este texto possibilita. 
Assim, em consonância com os pressupostos de uma sociedade sustentável, os programas educativos que objetivem a formação de educadores ambientais exigem processos pedagógicos "abertos, dinâmicos e criativos, nos quais os protagonistas - como sujeitos do processo estejam em atitude de aprendizagem permanente", como afirmam Gutierrez e Prado (1999, p. 37). E, para que isso ocorra e os sujeitos sintam-se compelidos à uma atuação voltada à transformação da sociedade, é necessário encontrar fórmulas e processos que favoreçam uma verdadeira implicação dos sujeitos no seu próprio processo formativo.

Além disso, sob o enfoque do empoderamento e ou incremento na potência de ação dos educandos, posso afirmar que a constituição destes espaços, alicerçados numa proposta que configura a participação e a busca de autonomia como eixos pedagógicos e objetivo final do processo, constituem-se em caminhos propícios ao estabelecimento de uma cultura emancipatória.

A fala dos entrevistados indica que houve modificações em seu cotidiano, e que isso é resultado da incorporação de conhecimentos e valores que permearam a proposta pedagógica do curso. O que me permite afirmar que uma proposta político-pedagógica que promova a apreensão da realidade, em suas várias dimensões, através da reflexão crítica e do confronto com essa realidade, é incorporada de maneira significativa pelos educandos, ao constituir-se em uma possibilidade concreta de intervenção na sociedade.

Nesse sentido, a realização de projetos de intervenção educacional e ou a constituição dos grupos PAP nas comunidades, possibilita a emergência de novos valores e novas atitudes, visto que confronta os educandos com os desafios de estabelecer uma nova prática pedagógica, destinada não apenas a transmitir conteúdos, mas a mediar a construção de alternativas aos problemas vivenciados pelos coletivos. Mais do que isso, os instrumentaliza 
para o enfrentamento de situações que comprometem a sobrevivência em condições dignas de outros coletivos, humanos ou não.

Pode-se inferir, portanto, que à medida que o sujeito se permite ser afetado pelo outro e pelas situações, constroem-se novas formas de ver 0 mundo e novas subjetividades.

Uma das questões a ser enfrentada por este estudo referia-se à identificação de indicadores que permitissem compreender em que momento ocorre o incremento na potência de ação dos sujeitos e, para além disso, se o curso promoveu este incremento. Constatei, contudo, que tal desafio necessita de um maior aprofundamento teórico, especialmente no que se refere à obra de Espinosa e a sua relação com outros campos de conhecimento, especialmente a psicologia, o que não foi possível de ser realizado no espaço de tempo disponível para a realização do referido estudo, sendo que essa questão faz parte das buscas previstas para o doutorado.

Utilizei, assim, algumas categorias apontadas por Sawaia (2001) e o estudo realizado por Sacardo (2001) em seu doutorado, referente à análise da participação para subsidiar a análise sobre o incremento ou não da potência de ação. Na fala dos estudantes do curso em foco percebe-se a presença de várias destas categorias, nem sempre de maneira isolada. Como afirma Sacardo (op.cit), constantemente elas se interpõem dificultando a sua decodificação para efeito da análise.

As falas evidenciam que a participação no curso possibilitou o "fortalecimento do sujeito e recuperação da sua auto-estima, do resgate dos sonhos, do desenvolvimento da afetividade, do incremento da solidariedade (...)" (op.cit.p, 135). Isto pode ser observado no envolvimento com as atividades de formação e organização dos grupos PAP nas comunidades. E demonstra a importância da práxis na constituição, não só de novos conhecimentos, como de novas subjetividades. 
À medida que foram estabelecendo-se os laços afetivos entre os alunos e destes com os membros do grupo PAP percebia-se que os encontros nos módulos presenciais convertiam-se em encontros alegres, em "espaços com calor" a partir da partilha dos medos, das angústias e da euforia com os trabalhos desenvolvidos junto às comunidades. Tornavam-se alegres, a despeito da presença dos sentimentos tristes, visto que um sentimento mais forte permeava todo aquele processo: o desejo de mudar e o desafio de contribuir para a modificação do real.

“(...) antes existia a vontade de mudar , a insatisfação e a vontade de mudar e agora a gente se potencializou, né. A gente se instruiu, agora acho que a facilidade é maior. Você já num tá só na base da vontade, já tem um embasamento, toda uma experiência pelo que já foi vivido no curso, nas aulas presenciais e também vivido na comunidade" ( $E$ 23, entrevista).

De acordo com a filosofia espinosana age-se quando, de posse de paixões e afetos alegres, reconhece-se como causa do desejo de querer. $\mathrm{Ou}$ seja o desejo de mudar, de interferir na realidade para construir uma outra sociedade, depende não só da idealização, mas da vontade de cada indivíduo. A idealização por si só não configura-se em mudança. Precisa-se idealizar e querer realizar o idealizado. A fala da aluna retrata essa transição necessária, podendo denotar que houve a passagem do pensamento de primeiro gênero (imaginativo) para o de terceiro (intuitivo).

Percebe-se também a presença de algumas das categorias identificadas por Sawaia (2001) como "legitimidade", "desejos individuais" e "auto-reflexão crítica". Possibilitou, ainda "criação de espaços com calor", "bons encontros cotidianos", "bons encontros públicos" e a constituição de "redes de apoio", como denota a fala abaixo. 
“(...) lá na escola mesmo, que eu trabalho, já fizemos desde o ano passado, eu propus e foi acatado pelos colegas, nós já realizamos alguns eventos voltados pra isso. Nós fizemos a gincana cultural e foi com toda a temática "Terra te queremos viva". Foi toda voltada pra isso, bastante participativa. Movimentou a escola, tanto a comunidade que a gente levou essa idéia. A comunidade pôde ver essa idéia incutida em todas as tarefas dessa gincana cultural. Foi muito bom. Esse ano a gente pretende botar outras idéias em prática" ( $E$ I, entrevista)

De certa maneira, percebe-se que o trabalho desenvolvido durante 0 curso possibilitou a estes sujeitos subverter no cotidiano as situações geradoras de sentimentos tristes: acomodação e desmotivação com a prática profissional, indiferença com o destino dos humanos e outros seres que nos rodeiam. Programas que buscam a mobilização individual e coletiva para a realização de mudanças devem compreender as emoções e os afetos, de modo a superar as paixões tristes, como o medo, que tramam contra nossa própria existência como componentes essenciais do processo educacional. Assim, o espaço de aprendizagem possibilitará o fortalecimento dos sentimentos e das paixões alegres que se converterão em ação transformadora. A fala abaixo ilustra bem esta situação.

"Acho que a comunidade de aprendizagem, ela fazia a gente sentir força pra continuar as realizações, as discussões. Tudo aquilo que a gente aprendeu quando a gente conseguia passar e a gente via que teve êxito, fazia com que a gente voltasse pra cá no próximo encontro e tivesse mais fortalecido pra continuar" (E 23, entrevista).

Cabe ressaltar que a comunidade de aprendizagem, mesmo que tenha restringido-se aos grupos de atuação nas comunidades, não 
conseguindo ser consolidada na dimensão desejada, possibilitou a "autoreflexão crítica", promoveu "bons encontros" resultantes da "alegria de estar entre amigos", além da solidariedade e da amizade. Pode-se inferir que esse resultado foi possível porque houve a "abertura à alteridade" pela maioria dos alunos, como indica essa fala.

"como eu diria também, outro que nos orientou muito e que acho que é válido em qualquer curso trabalhar é a questão do respeito à vontade do outro, do respeitar, ouvir e poder compartilhar e chegar a um denominador comum dentro do que propõe essas pessoas que fizerem esse curso" (E 23, entrevista).

Apesar dos depoimentos indicarem que os alunos consideram que 0 curso promoveu alterações no seu cotidiano - na esfera privada, pública e na intimidade, acredito que algumas questões devem ser observadas quando pretende-se planejar e implementar programas de formação de educadorescom a adjetivação ambiental ou não. Nesse sentido, apresento algumas considerações surgidas a partir das reflexões sobre este curso.

O processo seletivo deve ser compatível com os objetivos e a proposta do curso, portanto, necessita de um melhor planejamento utilizando mecanismos que possibilitem o ingresso de profissionais que se disponham a enfrentar os desafios representados por uma proposta que pretende implementar espaços de locução e que confronta-se com o paradigma vigente de ciência e sociedade.

A estrutura curricular dos programas deve ser aberta, dinâmica e flexível, de modo a facilitar a inserção da dimensão ambiental em uma abordagem que possibilite a análise e reflexão dos diversos contextos que compõem a realidade socioambiental. Mesmo que os programas sejam implementados de forma disciplinar, o projeto político-pedagógico deve 
promover o exercício interdisciplinar e integrado do conhecimento, evitando a sua compartimentalização. Penso, assim como Tristão (2001, p.241), que:

"a interdisciplinaridade torna-se um exercício para facilitar a migração de conceitos, a desterritorialização, enfim, a transversalidade. Mas, a inter ou a transdisciplinaridade só representam solução quando ocorre mudança na concepção do pensamento, ou seja, ligar o que esteve disjunto, "ecologizar" as disciplinas, contextualizá-las dentro das condições culturais e sociais que lhe são pertinentes"

É importante, também, que os sujeitos envolvidos no processo de elaboração e execução destes programas - coordenadores, professores e técnicos - compartilhem de um mesmo desejo e mobilizem-se para a consecução deste. Não é recomendado, assim como aconteceu no curso em análise, desenvolver um processo dessa natureza sem o envolvimento e comprometimento de toda a equipe executora, como vê-se na fala seguinte:

"Apenas ressalto a necessidade maior do envolvimento de mais docentes nessa proposta considerando que o curso proporciona uma integração maior comunidade X universidade" (E 13, caderno de campo).

Esse envolvimento é essencial para o estabelecimento de um projeto político-pedagógico amplamente debatido, em que as ações em sala de aula, o acompanhamento das atividades realizadas no campo e à distância e, acima de tudo, os princípios e objetivos sejam incorporados por todos.

Outra questão que merece um cuidado especial diz respeito à disponibilização de materiais instrucionais. $O$ acesso às instruções facilita $O$ entendimento dos sujeitos sobre as questões inerentes ao processo, evitando a geração de conflitos e de turbulências que, acredito, 
enfraqueceram o programa. Com isso não estou negando o caráter pedagógico que tais dimensões possuem e a sua importância para o processo de aprendizagem, entretanto o planejamento cuidadoso poderia evitar conflitos que, no caso em análise, resultaram em sentimentos de frustração e impotência não apenas dos alunos, mas também da coordenação do curso.

Acredito que a promoção de um processo educativo que realize-se presencialmente e à distância, sem perder o caráter dialógico, participativo e emancipatório, necessita de um maior aprofundamento por parte da própria equipe executora, buscando-se a explicitação de como se daria o processo e quais ferramentas seriam as mais adequadas para utilizar-se. Após esse entendimento, deve-se, reafirmo, apresentar aos educandos a proposta e os meios para a sua implementação.

Esse envolvimento e comprometimento também dizem respeito à universidade que deve compreender as especificidades e as necessidades demandadas por este tipo de processo que conduzem à uma ação acadêmica que busca aliar a competência técnica ao compromisso social. $\mathrm{O}$ cuidado com o suprimento de condições adequadas para que o espaço de aprendizagem constitua-se é imprescindível.

Acredito, pois, que tanto a concepção quanto as estratégias adotadas, no curso em foco, para a aprendizagem dos sujeitos são propulsoras da emancipação e do empoderamento dos grupos. E que a promoção desses espaços de aprendizagem é fundamental para que a liberdade, da maneira como a concebe Espinosa, seja conquistada, possibilitando que condições mais equânimes de sobrevivência - com justiça social, fortalecimento de afetos e emoções, respeito e compromisso com o ambiente, sejam implementadas. 
ANEXOS 
ANEXO A Proposta do curso

\section{CURSO DE PRÓ-GRADUAÇÃO “LATO SENSU” EM EDUCAÇÃO PARA SOCIEDADES SUSTENTÁVEIS.}

\section{A proposta do curso}

Constatada a carência de recursos humanos capacitados para a realização de atividades de extensão fundamentadas em princípios educacionais, cooperativos e de sustentabilidade, três universidades estaduais, duas baianas e uma paulista, optaram por realizar um convênio de cooperação técnica que Ihes possibilitassem um intercâmbio mais constante de experiências e reflexões nesta direção.

Um passo neste sentido está sendo dado com a realização de um Curso de Especialização em "Educação para Sociedades Sustentáveis", nas três regiões onde localizam-se as referidas universidades - Jequié, São Paulo e Feira de Santana.

Esses cursos voltam-se à capacitação de recursos humanos da região para atuarem na formação de agentes locais de sustentabilidade. Portanto, contribuir na formação de educadores para que eles contribuam na formação de novos educadores e para que esses também assumam semelhante tarefa em suas atuações cotidianas.

O princípio da práxis, do "aprender fazendo", orienta o método de interenção educacional, estimulando a formação, com os alunos do curso, de uma comunidade de aprendizagem que se depara com o desafio de construir o seu próprio conhecimento a partir de um desafio ainda maior, que é o de estimular e contribuir para a construção do conhecimento do outro o agente local de sustentabilidade.

Sustentabilidade compreendida nas dimensões apontadas por Sachs social, ambiental, econômica, cultural e espacial - mas que podem ser 
sintetizadas na busca da autonomia. Autonomia individual e coletiva do próprio futuro que. Num contexto de crescente globalização e inter-dependência, tem novos significados que precisam ser decodificados.

Contribuir para a compreensão do momento histórico que vivemos e para o "empoderamento", individual e coletivo, que possibilite o enfrentamento crítico, porém alegre e esperançoso, da construção de um futuro melhor passa a ser uma das tarefas centrais e mais desafiantes desse curso.

\section{Objetivos do curso}

1. Estimular e apoiar a formação de agentes locais de sustentabilidade;

2. Estimular e apoiar a capacitação de profissionais para atuarem na formação de agentes locais;

3. Contribuir para o fortalecimento de uma extensão universitária integrada ao ensino e à pesquisa e comprometida com o desenvolvimento de sociedades sustentáveis;

4. Contribuir para a recuperação, conservação e melhoria do meio ambiente e da qualidade de vida nas regiões onde o projeto irá atuar.

\section{Estrutura do curso}

O curso terá uma carga horária total de 408 horas presenciais e 242 à distância, totalizando 650 horas.

Podemos conceber este curso como centrado em três grupos de pesquisa - ação- participante (PAP). O primeiro, somos nós, dez professores da UESB que coordenam/deflagram a formação do grupo PAP dos alunos que participam do curso de especialização. Este segundo grupo responsabiliza-se pela formação do terceiro - grupos locais de agentes de sustentabilidade. 
O processo de formação dos participantes de cada PAP ocorre através do planejamento e da ação de intervenções educacionais sócio-ambientais.

O curso terá os seguintes módulos:

1. Estruturante - voltado a formação de uma "comunidade de aprendizagem", onde os participantes amadureçam como um grupo autogestionário para a construção do seu próprio conhecimento através o enfrentamento do desafio de atuar na formação de agentes de sustentabilidade nos municípios selecionados. Serão realizados reuniões com a equipe de professores do curso para apresentação da proposta de atuação do curso. Serão iniciadas as disciplinas sob responsabilidade de Luiz Antonio Ferraro Junior (Cooperação e Extensão Universitária), Marcos Sorrentino (Ação Coletiva, Cidadania e Educação) e Cláudia Coelho Santos (Educação Ambiental e Agenda XXI Local).

Estabelecimento de um sistema de conexão das pessoas e instituições envolvidas no curso, formando uma rede e lista de discussão, conectados a outras e possibilitando um exercício de educação à distância.

2. "Informativo": compõe-se das disciplinas voltadas a disponibilizem repertórios que instrumentalizem os participantes para intervenção educacional. Serão ministradas por Moema Viezzer (metodologia da Pesquisa-AçãoParticpativa), Eda Tassara (Pesquisa Intervenção), Carlos Mária Perez e Sônia Matos (Tópicos Especiais em Desenvolvimento Sustentável) e Marcos e Fábio Ferreira (Planejamento, Gestão e Política Ambiental), Elaboração de Projetos (Ester Maria de F. Souza e Alessandra Bueno de Grandi) e Geração de Trabalho e Renda com Sustentabilidade (Luiz Antonio Ferraro Junior).

3. Intervenção Educacional - destina-se a capacitação dos agentes locais e para atuação os municípios e/ou instituições parceiras. Serão realizados seminários para discussão e acompanhamento do processo de formação dos agentes e sustentabilidade. 
Note-se que a coordenação deste módulo estará por contados próprios alunos do curso de especialização, devendo-se definir dinâmicas específicas de trabalho para cada sub-grupo.

Os professores que serão referência e apoio para este módulo são: Cláudia Coelho Santos, Carla Patrícia Novaes luz, Carlos Maria Perez, Marcos Ferreira, Sônia Matos, Ester Maria de Figueiredo Souza, Alessandra Bueno de Grandi, Aa Cristina Duarte, Fábio Ferreira, Ana Angélica Leal Barbosa, Regina Terumi Yamaki.

\section{Avaliação}

1. Relatório/Caderno de campo

I semestre: descritivo.

II semestre : descritivo e analítico.

Os relatórios devem conter elementos para uma avaliação dos participantes em seu desenvolvimento durante o curso contemplando itens como:

- ação para o estabelecimento de parcerias com instituições locais;

- capacitação dos grupos de agentes locais e estudantes;

- participação em reuniões e reflexões sobre os textos lidos, nos momentos de ensino presencial e à distância e outros.

2. Seminário intermediário para relato sobre o estado da arte de cada intervenção (em julho).

3. Projeto de continuidade das ações dos agentes locais.

4. Seminário final com exposição dos trabalhos realizados (artigos; cartilhas; vídeos; ensaios fotográficos; teatro, etc). 
Como conseqüência dessas apresentações pretende-se realizar uma publicação com os artigos de cada grupo relatando as experiências vivenciadas.

Cada disciplina estabelecerá seus critérios de avaliação, relacionadas aos produtos esperados.

\section{Algumas questões a serem administradas pelo grupo.}

1. A escolha dos municípios, públicos alvo e instituições levando em consideração outros programas semelhantes em curso e os fatores positivos e negativos que devem pesar nessa escolha;

2. Promover um processo de sinergia e cooperação com os diferentes grupos, setores e tendências dentro da própria Universidade.

3. Concebermo-os e organizarmo-nos como um grupo de pesquisa-açãoparticipativa, que dá o exemplo de enfrentamento de desafios buscando neles sempre a dimensão educacional;

4. Sensibilizarmos os participantes para a compreensão e engajamento num curso que não pretende ser apenas um certificado de especialização, mas um compromisso político, humano e existencial com a Vida em todo seu potencial emancipador;

5. Todo o processo não tem respostas prontas. Em cada grupo instância dessa estrutura iremos nos deparar com as muitas turbulências que a participação propicia. Buscar a dimensão pedagógica desses conflitos e resolver os problemas conforme vão surgindo, utilizando-os para incrementar de forma articulada o planejamento já delineado, passa a ser um enorme exercício prático de inter-transdisciplinaridade, multirreferencialidade na busca de sentidos interpretativos e de soluções, mas fundamentada na compreensão da complexidade das intervenções educacionais e das questões sócioambientais. 
Os momentos presenciais deverão ter por objetivo:

1. Estimular a ação dentro de uma perspectiva dialógica que contemple a diversidade social, econômica, cultural e ambiental dentro dos grupos;

2. Estrutura as ações de cada grupo de modo a criar um espaço para autoavaliação e auto-gestão de cada grupo PAP;

3. Possibilitar acesso às ferramentas demandadas a partir da ação. 
ANEXO B Projetos desenvolvidos pelos/as estudantes

Os/as estudantes dividiram-se em sete grupos e desenvolveram os seguintes projetos:

- PAP - Um caminho para a sustentabilidade - Grupo inicialmente formado por quatro pessoas que, ao término do primeiro encontro decidiu realizar o projeto de intervenção educacional no município de Barra Choça-Ba, onde uma integrante já desenvolvia atividades de educação ambiental. Por divergências quanto à condução do projeto já "que a esse trabalho era dado um direcionamento que não "casava" com a proposta do curso (...) e com a pretensão de parte do grupo: de construir a equidade tendo em vista a alteridade" - Aluna integrante do grupo - o grupo decidiu procurar outro local para a realização da intervenção. Em abril de 2000 decidiram realizar o trabalho no município de Vitória da Conquista-Ba, especificamente na rua Henriqueta Prates, Bairro Petropólis, próximo à Reserva Florestal do Poço Escuro.

Ao término do projeto desenvolvido pelos/as estudantes chegouse aos seguintes resultados: i) aumento da auto-estima dos moradores que passaram a se preocupar com a rua de forma solidária e cooperativa; ii) autonomia do grupo de moradores que, após identificarem os problemas e orientação inicial dos alunos, começaram a apresentar suas próprias propostas e executá-las a exemplo da comissão formada para visitar e entregar um abaixo assinado, também organizado por eles contando com 300 assinaturas, à Empresa de Águas e Saneamento da Bahia - EMBASA e reivindicar a solução do problema do esgotamento sanitário; consciência da necessidade de participação em todas as instâncias, a exemplo da mobilização para montar uma chapa e participar da eleição da associação de Moradores do Bairro bem como da mobilização para criar a Frente de Ação do Alto Petropólis - FAAP com o intuito de organizar a comunidade para discutir os problemas do bairro, 
cobrar posições da associação de moradores e da prefeitura e contribuir para a solução dos mesmos.

Pode-se indicar como resultado da intervenção a consolidação de:

"um grupo capaz de tomar decisões, projetar, disponibilizar informações, buscar espaços, intervir num processo. Não existe na HP um grupo grande, mas um grupo de qualidade, sempre motivado, que tem a esperança como sinal de resistência, a utopia como sonho do possível e a co-responsabilidade como desculpa para buscar alternativas. É o querer e o desejar que move esse grupo e que o faz comprometer-se e objetivar cada passo" (Relatório do grupo).

Durante a apresentação do grupo contamos com a participação de uma moradora da referida rua que nos contou como aquele trabalho tinha modificado a sua vida e a compreensão de suas potencialidades para enfrentar os problemas e os desafios: entrar na escola para aprender a ler escrever a fim de "fazer o próximo baixo assinado", participar do projeto Amigos da Escola fazendo parte de um mutirão que pintou o muro da escola, apresentar uma chapa para concorrer presidência da associação de moradores, entrar na faculdade para falar a pessoas que "falam direito", logo ela, que fala "tão errado"...tudo aquilo era o resultado de uma ação que "levou a luz" aquelas pessoas, como disse Minervina.

- Escola Ambiente Saudável - Projeto desenvolvido por seis alunos não Colégio Estadual Professor Magalhães Neto - CEPMN, situado no município de Jequié-Ba. A partir de reuniões com a Diretoria e Coordenação da escola, que deram total apoio à iniciativa dos alunos da especialização, dentre os quais estava um professor da escola, e liberdade de atuação naquele espaço foram realizadas outras reuniões com funcionários, alunos líderes de classe, professores, o colegiado da escola (composto por pais, professores e 
alunos) com 0 intuito de identificar o público com o qual trabalhariam. Aproximadamente 28 pessoas, sendo a maioria estudantes do ensino médio, interessaram-se em participar do grupo PAP e estabeleceram um agenda de reuniões quinzenais nas quais, através do uso de diferentes estratégias e técnicas (vídeos, dramatizações, palestras, discussão de textos, oficina de futuro) os problemas da escola foram identificados e estabeleceu-se a Agenda 21 do Pedaço.

"O nosso objetivo: Contribuir para a formação de agentes transformadores, autônomos, participativos e comprometidos na escola e comunidade, através do desenvolvimento de ações que possibilitem a manutenção do ambiente saudável" (Relatório do grupo).

O grupo PAP decidiu que a prioridade seria um trabalho mais efetivo com os segmentos que constituem a escola visando uma melhor "preservação e conservação do meio ambiente escolar", o tema a ser abordado seria o lixo. A partir daí foram realizadas várias ações, como: exibição de filmes, distribuição de folhetos informativos, teatro nos intervalos das aulas, colocação de baldes para deposição adequada do lixo, um ciclo de palestras com participação de vários profissionais da cidade versando sobre a temática, oficina de reciclagem de papel.

Todas as atividades eram planejadas e avaliadas nas reuniões quinzenais do grupo PAP. Como outra prioridade foi indicada a necessidade de implantação de uma horta comunitária construída pela comunidade escolar e que suprisse as verduras e legumes utilizados na merenda escolar.

Como resultado vê-se a constituição de um grupo formado quase na sua totalidade por adolescentes que demonstraram uma capacidade enorme de compreensão da realidade local e dos benefícios oriundos da união das pessoas para discutir, propor e implementar ações que visem a melhoria da qualidade de vida da coletividade. 
“(...) hoje a sustentabilidade do trabalho é a nossa grande aspiração, que ele possa prosseguir, que o grupo PAP com autonomia e participatividade deslanche, pois já temos uma Agenda 21 Participativa construída, com Oficina de Futuro, Soluções e Problemas, e um Plano de Ação ( o Trabalho do Lixo e a Horta Comunitária) para ser desenvolvido no decorrer de 2001. O grupo PAP nos proporcionou uma troca riquíssima de experiências, e idéias maravilhosas. Apesar das mudanças constantes e da falta de continuidade em relação a algumas ações, o que foi normal pois construímos o trabalho em cima de erros e acertos, fomos reelaborando o projeto ao longo do percurso de acordo com o que a realidade foi nos oferecendo, podemos dizer que a semente já está lançada...Que atingimos nosso objetivo" (Relatório do grupo).

O grupo apresentou um vídeo com depoimentos dos integrantes do grupo PAP e da diretora do colégio.

- Transformação de valores: Um ponto de partida para a formação de um grupo PAP autônomo - Projeto desenvolvido no Colégio Polivalente Edivaldo Boaventura, situado no Bairro Jequiezinho, no município de Jequié-Ba por quatro alunas. O fato de uma das integrantes da equipe ser professora na escola foi fundamental para a escolha do local da intervenção pois facilitou a "entrada" no ambiente escolar e, assim como a outra escola, contou com o total apoio da direção do colégio para o desenvolvimento do trabalho. O Colégio Polivalente é uma escola conhecida em Jequié devido às iniciativas do seu corpo docente no que tange aos trabalhos desenvolvidos relacionados à preservação do meio ambiente e ao resgate da cidadania.

O grupo encontrou, portanto, um grupo de alunos voluntários e bastante receptivos, como se percebe nas visitas e materiais elaborados durante 0 processo de intervenção, que participaram das reuniões semanais realizando atividades diversas: leitura e discussão de textos, dinâmicas de grupo, 
passeios, oficina de reciclagem de papel, oficina de futuro de onde surgiu a Agenda 21 do Pedaço.

Nesse trabalho buscou-se, antes de tudo, uma maior conscientização dos integrantes do grupo PAP sobre os problemas sócio-ambientais em pauta e o comprometimento deles enquanto grupo e com o planeta como um todo. Priorizou-se a discussão sobre os valores essenciais para o alcance de um mundo mais justo, equilibrado e feliz.

Como resultado tem-se elaboração da agenda 21, um vídeo documentário e a criação do Grupo JOCA - Jovens Cidadãos Ambientalistas, pensado e criado pelos integrantes do Grupo PAP.

"No primeiro dia eu gostei muito, vi que o trabalho era muito bom (...) porque desenvolveu mais a gente e é bom porque trabalhou com a natureza, trabalhou desenvolver mais com o grupo, trabalhou a solidariedade, respeito, paz. E paz no mundo quase não tem. Aí é bom porque assim, assim todo mundo vai aprendendo mais a valorizar um mundo melhor, né!" (Aluna do Colégio Polivalente, integrante do grupo PAP, 12 anos em depoimento apresentado no vídeo).

- Projeto Rio Vivo: Uma ação para o desenvolvimento sustentável do Rio Preguiça - Esse projeto de intervenção foi realizado por cinco alunos do curso de especialização no município de Aiquara-Ba. Assim como nos projetos citados anteriormente o fato de um dos integrantes do grupo estar trabalhando na Prefeitura Municipal deste município influenciou a escolha do grupo em desenvolver as atividades nessa localidade.

“..partimos para o nosso primeiro momento no município de Aiquara, a visita aconteceu no dia 18.03.200, e iniciamos conversando com o secretário de Agricultura do município (...) que nos informou sobre os principais problemas sócio-ambientais do município. Em seguida 
visitamos os seguintes locais(...) Tivemos uma visão em âmbito geral da realidade do município, com Eloi, coordenador da Vigilância Sanitária de Aiquara, conhecemos as doenças que mais acomete a população...(..) Num outro momento nos reunimos na Câmara de Vereadores com representantes, líderes comunitários, políticos e estudantes, a fim de esclarecer acerca da proposta metodológica do curso e identificar a partir da ótica deles os principais problemas vivenciados. O nosso projeto de ação consiste em integrar e capacitar a comunidade de Aiquara na área da sustentabilidade, a partir da formação de agentes multiplicadores, para que possam identificar os problemas e buscar mecanismos de soluções. $\mathrm{Na}$ efetivação dessa proposta, realizamos várias visitas no município, conversas informais e reuniões com gestores municipais, lideranças comunitárias e representantes das classes populares, afim de construir uma proposta conjunta de ação numa perspectiva da preservação ambiental e do desenvolvimento sustentável".

"Dentre os problemas os mais citados foram: falta de saneamento básico, esgoto sem tratamento lançado no rio, lixo, desmatamento e matadouro sem condições de funcionamento. Os problemas colocados pela comunidade foram coincidentemente os mesmos diagnosticados pelo grupo durante visita pela cidade" (relatório do grupo).

Do que foi relatado percebe-se o direcionamento da discussão para o problema do rio sendo que as demais técnicas, inclusive a Oficina de Futuro, giraram em torno do problema indicado pelo grupo de alunos, por mais que houvesse o aceite da população.

Após a realização dessa atividade que aconteceu em março/2000, reunião com as lideranças locais, os alunos retornaram ao município em poucas 
ocasiões para a preparação do I Seminário em Educação Ambiental do Município.

"Demos continuidade ao nosso trabalho em Aiquara de maneira um pouco diferente, conversando, fotografando, tudo isso por causa da campanha política, não queríamos que dessem uma conotação eleitoral às nossas atividades e percebemos que o clima na cidade não estava propício, pois trata-se de um município pequeno e as disputas são muito acirradas, onde todas as pessoas costumam se envolver diretamente, reuni-las naquele momento não seria nada bom, achamos mais prudente esperar tudo isso parar, acredito ter sido uma decisão acertada".

Esse foi um dos motivos que nos levaram a questionar a forma como o grupo conduziu os trabalhos, pois a vinculação direta do projeto às autoridades locais e, mais do que isso, implementado por uma profissional que possuía cargo de confiança na atual gestão municipal, comprometia seriamente o desenrolar das ações. Especialmente em municípios como esses que a comunidade divide-se entre dois grupos, ideológicos idênticos, que alternam-se no poder é sempre problemático atuar da forma como o grupo optou.

O Seminário citado anteriormente foi realizado em novembro, contando com a participação de autoridades e lideranças locais e de municípios vizinhos , bem como de professores e de algumas pessoas da comunidade. Foi um evento organizado com um cunho informativo bem explicito, na medida em que contou com toda a formalidade inerente aos eventos técnicos: com convite para compor a mesa por parte das autoridades e palestrantes vindos da universidade.

Todo o evento foi organizado e coordenado pelos alunos da especialização que ao final dividiram os participantes em três grupos para debater temas previamente estabelecidos, sendo dois deles relacionados à preservação do rio preguiça e o outro sobre projetos ambientais de interesse da 
comunidade. Como atividade final foram escolhidos os participantes do grupo PAP de Aiquara.

"Inúmeras reuniões ocorreram com discussões, leituras de textos, projeção de vídeos e começamos a realizar uma série de atividades propostas pelas pessoas participantes do seminário e grupo PAP: Passeata de conscientização com a participação espontânea principalmente de jovens e crianças, mas também dos adultos e idosos: mutirão de limpeza do Rio Preguiça; palestra do grupo na Semana Pedagógica do Município; montagem da peça teatral sobre a questão ambiental, mobilização de alunos e professores nas escolas, entre outras" (Relatório do grupo).

Os resultados efetivos desse processo pode ser percebido durante a apresentação de algumas pessoas que compõem o grupo PAP na atividade de encerramento do curso de especialização.

"Esse trabalho realmente foi de uma importância muito grande prá nós, que com certeza não se acaba, não se encerrou com a saída do grupo, mas que vai permanecer pelo fruto grande que ele conseguiu produzir que foi abrir a nossa consciência para o problema que vivíamos mas que ainda não tínhamos o despertar para chegar a uma solução" (Moradora de Aiquara, integrante do grupo PAP).

- Sensibilização e melhoria de qualidade de vida entre o grupo vida e a comunidade de Lafayete Coutinho - $O$ grupo inicialmente desenvolveria suas atividade no município de Maracás, mas devido à falta de apoio por parte da prefeitura decidiu por realizá-las no município de Lafayete Coutinho. Realizado por um grupo composto por cinco alunos da especialização esse projeto assemelha-se em diversos pontos ao descrito anteriormente, 
principalmente na maneira de "entrada" na comunidade, uma vez que antes de estabelecer os contatos com a população de modo geral, os alunos reuniramse com as autoridades locais dispondo-se à solucionar alguns problemas ambientais indicados por estes, especialmente os relacionados aos resíduos sólidos, interesse inicial do grupo.

"O professor Marcos Sorrentino orientou quanto as etapas do Projeto e o grupo de que faço parte optou pelo reaproveitamento e armazenamento do lixo. Inicialmente pensado para Maracás, só em Lafayete Coutinho (...) foi viável implantá-lo" (E 7, caderno de campo)

"fizemos contato com a Prefeitura, a qual deu-nos total apoio em iniciarmos os trabalhos nesta cidade. A visita da equipe a cidade de Lafayete Coutinho, foi transformada em um seminário "10 Encontro Ambiental de Lafayete Coutinho" ... , tendo como participantes nós, alunos da Pós-graduação e foram convocadas: autoridades e pessoas importantes da comunidade" (Relatório do grupo).

Nesse caso também houve uma apresentação formal dos membros do grupo sobre os objetivos que levaram à realização do encontro, seguida por uma explanação sobre o que seria a sustentabilidade ambiental desejada. Nesse aspecto, especialmente, fica a preocupação de como tais informações foram transmitidas já que ao longo do curso observou-se a falta de clareza desses alunos no que dizia respeito à sustentabilidade de modo geral e, mais importante, sobre a necessidade do estabelecimento de processos eminentemente participativos desde a concepção até sua execução.

Assim como o grupo anterior esse também privilegiou o papel do poder local. Entretanto como essa condição foi apontada no início do trabalho houve possibilidade de criação de dois grupos PAPs: um ligado ao poder local e o outro constituído por pessoas da comunidade. Com esse grupo realizou-se uma 
Oficina de Futuro para elencar os problemas prioritários. Assim como no grupo inicialmente formado a prioridade recaiu sobre o problema do lixo, conforme indicado pelos alunos do curso.

É importante registrar que no município existia um grupo ecológico MEL - que por " problemas particulares de alguns integrantes com o prefeito da época (...) caiu no anonimato". A chegada do grupo ao município promoveu a reestruturação do grupo.

Dando continuidade ao projeto foi realizado o II Encontro Ambiental, tendo como tema o Lixo urbano e seus destinos. Os participantes dividiram-se em três grupos: Educação ( professores), Comunidade (pode-se falar que reuniu o "povo" de modo geral) e Administração (prefeito, secretários e vereadores) que ao final apresentaram as seguintes propostas: i) implantação de um sistema de coleta seletiva na escola; ii) conscientização da comunidade através de conversas informais sobre o problema do lixo; e iii) participação em reunião na câmara de vereadores reivindicando uma área para a construção do aterro sanitário.

- Exploração Sustentável dos recursos pesqueiros do Rio Grande - Projeto desenvolvido no município de Barreiras-Ba, por um aluno que atuou junto à Associação dos Pescadores Profissionais Amigos do Vale do Rio Grande - ASPAVARG visando constituir um grupo PAP com os pescadores que atuariam como agentes de sustentabilidade dentro de um processo de exploração pesqueira. Como residia e trabalhava a cerca de $800 \mathrm{~km}$ de Jequié o aluno não pode contar com o auxílio de nenhum colega do curso para a realização do projeto, no entanto uma das primeiras ações foi a busca de parcerias entre os colegas de trabalho e outros. Dessa forma contou com o apoio de uma pedagoga e de outros funcionários da Empresa Baiana de Desenvolvimento Agrário - EBDA para o desenvolvimento do projeto.

Como técnicas e estratégias para a coleta de dados optou-se por: acompanhamento das reuniões da associação de pescadores e com os 
agentes financeiros, com a finalidade de estabelecer um elo com os mesmos, bem como conhecer o funcionamento da ASPARVASG, sua história e outros; um questionário com 0 intuito de traçar o perfil sócio-econômico dos pescadores; entrevistas semi-estruturadas e análise documental.

Após a fase de "conhecimento do ambiente" foi realizada a Oficina de Futuro objetivando "a formação de um grupo PAP, o qual irá criar um modelo de gestão, com vistas a sustentabilidade, detectando problemas e descobrindo potencialidades para resolvê-los." O projeto centrava-se no problema vivido pelos pescadores na época do defeso em que ficavam sem uma renda que suprisse suas necessidades, apesar do recebimento de uma ajuda governamental. A expectativa era a de estabelecer um processo dialógico que conduzisse os pescadores a analisar o problema do defeso e da preservação dos ecossistemas não apensa no que concerne à geração de renda, mas como condição para a sobrevivência de todas as formas de vida. As atividades realizadas caminharam no sentido de construção de uma consciência coletiva do problema, da intenção de resolvê-lo e do planejamento de ações para solucioná-lo.

Como resultado vê-se a disposição dos membros da ASPAVARG e representantes do IBAMA de dialogarem sobre: o momento correto para o estabelecimento do defeso, utilização dos barcos dos pescadores para a fiscalização da área a fim de evitar a ação dos pescadores que descumprem o acordo, busca de alternativas para o incremento da renda dos pescadores durante o defeso, ação de educação ambiental voltada a atingir todos os membros da ASPAVARG e demais pescadores da região.

- Buscando a Sustentabilidade no Povoado da Cachoeirinha. Inicialmente contou com a participação de seis integrantes e, ao final, ficaram quatro estudantes para a implementação das atividades. 
Optaram por trabalhar no município de Jequié, Povoado da Cachoeirinha, periferia da cidade. Atuaram junto à Associação de Moradores da Cachoeirinha, por considerarem que assim teriam acesso mais fácil aos moradores, além de contar com a ajuda da Presidente da referida associação, aluna da UESB.

Inicialmente pretendiam trabalhar com o problema do saneamento básico e ou poluição do Rio das Contas, visto que através das visitas realizadas e do levantamento de dados secundários, constataram um alto índice de parasitoses ( cerca de $70 \%$ ) dos moradores. Contudo, ao realizarem a primeira reunião com a participação de alguns moradores, elegeu-se como problema mais urgente a ser enfrentado, a questão do desemprego.

Para tentar solucionar o problema os/as estudantes buscaram parcerias diversas (SEBRAE, Banco do Nordeste do Brasil, UESB, Fundo de Apoio ao Trabalhador), realizando reuniões com a participação de técnicos desses órgãos e os moradores no intuito de viabilizarem uma iniciativa que promovesse a renda dos moradores.

Percebe-se, dos relatos, que a atuação desses estudantes pautou-se pelo paternalismo e ou assistencialismo, tomando as iniciativas para solucionar o problema identificado e não mediando a discussão, como proposto pelo curso.

Durante as apresentações finais do curso, contou-se com a participação de um morador local que contou como o projeto foi implementado. 
ANEXO C Roteiro da entrevista

Tendo em vista que a proposta do curso de Especialização em Educação para Sociedades Sustentáveis intencionou a formação de agentes locais de sustentabilidade, a partir da compreensão de que o curso deveria possibilitar a potência de ação dos sujeitos envolvidos,

1. Qual foi o significado do curso de Especialização em Educação para Sociedades Sustentáveis para a sua prática cotidiana?

2. Quais os conceitos, conteúdos você considera importantes serem trabalhados na formação do educador ambiental voltado à formação de agentes locais?

3. E quais os princípios?

4. Você acredita que esses conceitos e princípios estavam presentes no curso?

5. Você acha que ocorreram deficiências na proposta do curso que dificultaram a apreensão de tais conceitos e princípios pelos alunos?

6. Quais as principais virtudes desse curso?

7. Como você $v$ a distribuição/sequenciamento das disciplinas

8. E o período/duração dos encontros?

9. curso norteou-se em três eixos; a comunidade de aprendizagem, a pedagogia da práxis e os conteúdos. î) Qual a sua compreensão sobre a comunidade de aprendizagem? ii) Você acredita que ela se constituiu no curso?

10. Como você vê projeto de intervenção educacional enquanto um dos eixos norteadores da proposta pedagógica?

11. Você está se sentindo potente para atuar na realidade no sentido de construir os seus ideais de sociedades sustentáveis?

12. curso de alguma forma teve influência nesse sentimento? 
ANEXO D Entrevistas E 2 e E 5

Entrevistadora: Eu queria saber, inicialmente, qual foi o significado do Curso de Especialização em Educação para Sociedades Sustentáveis na sua prática cotidiana?

Estudante 2: O significado foi muito positivo devido à forma de ... As mudanças com as quais a gente passa a vê o mundo de outra forma, os conceitos que a gente tinha, os conceitos formados a respeito de certas coisa passa a mudar a partir do momento das aula do curso, da vivência também nossa em campo. As mudanças são imensas. Nem pode dizer nunca que saiu do jeito que entrou porque foram mudanças totais.

Entrevistadora: Vou fazer duas perguntas que não são diretamente ligadas ao curso: se você fosse montar um curso de formação de educadores ambientais, que formem agentes locais (como foi o de vocês), quais os conceitos e os conteúdos que você acha importantes de serem trabalhados ?

Estudante 2 Os conceitos que eu acho importantes serem trabalhados... Os que foram trabalhados conosco são muito importantes, como o de sustentabilidade, meio ambiente, que a gente tinha um conceito totalmente diferente. É muito importante esse tipo de conceito que se vê de forma nova, com uma outra visão mesmo. Conceitos como eu acho que a questão da socialização, a questão do viver em comunidade, a questão também do que seria agente de sustentabilidade. Esse é um conceito assim que seriam cruciais na caminhada de um curso em educação pra sociedades sustentáveis.

Entrevistadora: E quais princípios, além desses conceitos você acha que também deveriam estar nessa proposta?

Estudante 2 Princípios é acho que, eu diria ... Você quer dizer princípios em que sentido?

Entrevistadora: Tipo autonomia... 
Estudante 2 Sei, são princípios básicos pra tratar já que é um curso voltado para o despertar da comunidade local, né. Um curso que põe sua visão para as pessoas... Eu acredito que esse mesmo que você acabou de citar como autonomia, como participação e envolvimento da comunidade com os seus problemas. Como eu diria também, outro que nos orientou muito e que acho que é válido em qualquer curso trabalhar é a questão do respeito à vontade do outro, do respeitar, ouvir e poder compartilhar e chegar a um denominador comum dentro do que propõe essas pessoas que fizerem esse curso.

Entrevistadora: Você acha que estes conceitos e princípios que estavam presentes no curso de especialização que você fez?

Estudante 2: Acredito que sim. Claro que há uma coisa ou outra, uma falha ou outra, mas era claramente visível esses conceitos dentro do curso.

Entrevistadora: Você falou em uma falha ou outra, então você acha que falhas ocorreram. E essas deficiências dificultaram por parte dos alunos a apreensão desses conceitos e destes princípios?

Estudante 2: De início não digo nem falhas, mas acho que era porque tava começando mesmo, é uma proposta nova, daí a gente se certifica, se orienta, se vê, se enxerga dentro do que era que nos estava sendo proposto que ainda ficou meio obscuro e a gente foi descobrindo meio que aos pouco. Não foi assim: Oh, vocês tem que fazer isso e vai ser assim e assim. Não foi uma coisa pronta, a descoberta foi aos poucos, de acordo como os módulos iam andando a gente ia vendo, acertando e errando, desenvolvendo alguma atividade, a atividade não era bem essa, a gente ia refazer de novo.

Entrevistadora: Então você acha que teve uma falha específica?

Estudante 2: Específica não diria.

Entrevistadora: E virtudes? O curso teve virtudes? E, se teve, quais seriam essas virtudes?

Estudante 2 É a questão de uma das grandes virtudes desse curso que eu achei, um curso que incentiva a gente a sonhar. Sonhar com um mundo melhor, sonhar com mudanças, com transformações e sonhar não só a título de 
ficar a título de pensamento, a título de utopia, sonhar prá busca realizar, né. O sonho caminhando junto com a possibilidade da realização. Essa realização que seria através de tudo o que a gente produziu no curso e que vem surtindo efeitos. Hoje eu tenho, assim, notícias ótimas do que aconteceu em Aiquara e ainda acontece coisas ligadas a esse curso lá.

Entrevistadora: Como você viu a distribuição ou seqüência das disciplinas?

Estudante $2 \mathrm{Eu}$ não achei ruim, não. Porque nós iniciamos de uma forma bem leve, não foi logo, como eu já disse anteriormente, não foi logo mostrando de vez: é isso, é isso. A aprendizagem veio com o tempo, com as disciplinas. É lógico que tiveram disciplinas que a gente se identificou, outras menos, alguns professores que a gente gostou mais, uma questão de identidade mesmo. Mas acho que todas foram bastante importantes e também a seqüência acho que foi boa.

Entrevistadora: E sobre a duração dos encontros o que você tem a dizer?

Estudante 2: Os encontros presenciais?

Entrevistadora: É, os presenciais.

Estudante 2: Bem, a gente, de início, nós tínhamos algumas dificuldades nos encontros por causa da questão da leitura. A gente tava lendo pouco e aí na hora que se encontrava tinha coisa que a gente tava meio perdido. Mas a duração dos encontros era melhor que a gente dispusesse de mais tempo. Mas eu acho que foi, como era o primeiro curso, talvez em um outro possa distribuir melhor pra ver se o tempo não seja tão corrido. Tinha disciplinas que eram corridas. A gente queria até saber mais, mas era um pouquinho corrido.

Entrevistadora: Você lembra que quando apresentamos a proposta do curso dissemos que ele norteava-se em três eixos: os conteúdos, a comunidade de aprendizagem e a pedagogia da práxis, que seria através dos projetos de intervenção. Qual sua compreensão da comunidade aprendizagem? 
Estudante 2: A comunidade aprendizagem eu compreendo como um ... acho que é o eixo que daria mais impulso pra gente gostar do curso, porque dentro da comunidade aprendizagem a gente via as coisas acontecendo. Tudo o que a gente tirava de proveito dos encontros, quando nós partíamos pra comunidade aprendizagem isso se realizava, não como uma fórmula, mas tudo aquilo que a gente conseguia de referencial aqui, a gente conseguia expor na realidade da gente, isso retornava de forma muito positiva. Acho que a comunidade de aprendizagem, ela fazia a gente sentir força pra continuar as realizações, as discussões. Tudo aquilo que a gente aprendeu quando a gente conseguia passar e a gente via que teve êxito, fazia com que a gente voltasse pra cá no próximo encontro e tivesse mais fortalecido pra continuar.

Entrevistadora: Então você acha que a comunidade de aprendizagem era a comunidade de Aiquara? É isso?

Estudante 2: Isso.

Entrevistadora: E o projeto de intervenção educacional, como você compreende?

Estudante 2 É extremamente importante. Faz com que a idéia, ela se expanda, não fica assim restrita a um grupo de algumas poucas pessoas. Por que nós, como fomos com essa proposta de formar educadores ambientais, a partir daí a gente pôde ver que a cidade inteira se contagiou. A gente pôde passar a idéia pra diante com os professores, aos trabalhadores rurais, com as pessoas que eram os garis da cidade. Então, essas pessoas todas que se reuniam lá, elas faziam a coisa acontecer na cidade toda. É uma comunidade pequena e que um ia passando pro outro e que outras pessoas, que às vezes nem tava no grupo, a gente passava na rua, perguntava, queria saber como é que tava, como é que era. Os próprios alunos se interessavam bastante. Acho que essa forma de fazer, acho e que foi bem positiva sim. 
Entrevistadora: E agora, depois do curso terminado você está se sentindo potente para atuar na realidade no sentido de construir os seus ideais de sociedades sustentáveis?

Estudante 2 Com certeza. Por que agora além... antes existia a vontade de mudar, a insatisfação e a vontade de mudar e agora a gente se potencializou né. A gente se instruiu, agora acho que a facilidade é maior. Você já não tá só na base da vontade, já tem um embasamento, toda uma experiência pelo que já foi vivido no curso, nas aulas presenciais e também vivido na comunidade. Lá na escola mesmo, que eu trabalho, já fizemos desde o ano passado - eu propus e foi acatado pelos colegas - nós já realizamos alguns eventos voltados pra isso. Nós fizemos a gincana cultural com a temática "Terra te queremos viva". Foi toda voltada pra isso, bastante participativa. Movimentou tanto a escola quanto a comunidade que a gente levou essa idéia. A comunidade pode vê essa idéia incutida em todas as tarefas dessa gincana cultural. Foi muito bom. Esse ano a gente pretende botar outras idéias em prática.

Entrevistadora: Então você quer dizer que o curso influenciou nesse sentimento?

Estudante 2 Totalmente, porque eu já trabalho nessa área a 8 anos. Vontade eu tinha, mas nunca fiz nada e a partir do curso idéias surgiram e a gente vai botando essas idéias em prática. 


\section{Entrevista E 5}

Entrevistadora: Qual foi o significado do curso de EA para sociedades sustentáveis na sua prática cotidiana?

Estudante 5 É...bom, de início, como toda atividade que a gente desenvolve dentro da universidade e nas atividades até de vida mesmo, sempre fica alguma coisa e aí, como especificamente uma atividade pedagógica, uma atividade voltada prá produção de conhecimento, desenvolvimento de prática de desenvolvimento sustentável é (...) ficou (...) vamos dizer assim: ficou no mundo, na verdade. Tanto é que no dia-a-dia você é capaz de ações que nos leva a perceber a grande importância que teve todo aquele conhecimento que foi desenvolvido durante o decorrer do curso, mediante a facilidade que a gente resolve e supera esses problemas que diariamente a gente encontra, principalmente no meio do convívio do trabalho né. Esses problemas, já que eu trabalho com fiscalização na área de saúde e na área ambiental também, no qual a gente nunca pode deixar de lado o sócio-econômico-político das coisas, e tentando buscar uma visão é, digamos assim, no contexto da vigilância sanitária, no contexto da saúde pública, no contexto do meio ambiente, de modo que a gente, ao mesmo tempo que fiscaliza, que cobra, que às vezes chega até a impor alguma coisa a gente consegue mediante o que a gente aprendeu né, não impor tanto e tentar achar uma alternativa qualquer, resolver a situação que seria no caso uma das melhores formas de resolver os vários problemas que a gente encontra nessa área. $\mathrm{Na}$ área de educação também a mesma forma.

Entrevistadora: Agora se você fosse propor um curso voltado a formação de educadores ambientais onde esses educadores ambientais também fossem capacitados para formar agentes locais, quais os conteúdos e conceitos você acha necessários conter nessa proposta?

Estudante 5 É ... de modo geral ou assim na área de educação? 
Entrevistadora: Nessa área, no curso de formação de educadores ambientais para sociedades sustentáveis.

Estudante 5 Eu diria que ... até porque foi vivenciado durante o curso e foi bem ... uma questão que marcou bastante quando a gente foi na comunidade desenvolver um trabalho educacional e a comunidade não queria, é, o problema da comunidade era totalmente diferente dos problemas que a gente tentou identificar logo no começo e eu creio que na maioria das vezes é o problema. Acho que seria mais interessante se você buscasse criar com essas pessoas ou desenvolver técnicas ou buscar fazer a pessoa desenvolver situações e nessa prática de desenvolve situações as pessoa pudesse aplica, desenvolver técnicas. Não técnicas já existentes, mas que pudesse adaptar situações a situação que eles vivem quotidianamente. É a pessoa adquirir uma flexibilidade tal que em qualquer das circunstâncias, seja na educação, seja na área técnica, seja no dia a dia, seja enfim na vida cotidiana, na vida familiar social desenvolver esses conceitos de E A, de desenvolvimento, de tudo o que é relacionado com isso .

Entrevistadora: E quais princípios deveriam ter essa proposta?

Estudante 5 É, os princípios seriam, eu acho assim que a questão do desenvolvimento sustentável e cultura. Cultura, essa questão social, a questão de, sei lá ... ética. Trabalhar mais com essas coisas.

Entrevistadora: Você viu que o curso é para "sociedades sustentáveis " e vocês falam o tempo todo de "desenvolvimento sustentável". Por quê? Tem diferença as duas propostas?

Estudante $5 \mathrm{Eu}$ acho que não. Sociedades sustentáveis e desenvolvimento sustentável eu acho que estão ligados. Pode até, sei lá, .... é, eles podem até ser mais específicos : sociedade sustentável e desenvolvimento sustentável.

Entrevistadora: Com relação a esses princípios e conceitos que você falou antes, você acha que o curso daqui, que a gente ofereceu, tinha essas características? 
Estudante 5 Tinha. As disciplinas que a gente trabalhou durante o curso buscaram atingir esses princípios e até as práticas que a gente desenvolveu durante o curso e nosso trabalho, a gente viu que o curso deu margem a você buscar trabalhar com o que foi aprendido tanto em colégio como em comunidade. É claro que cada lugar desse tem uma estrutura diferente, uma cultura talvez diferente e que acaba envolvendo todos os princípios, na verdade né.

Entrevistadora: Você acredita que na proposta pedagógica do curso ocorreram dificuldades que dificultaram a apreensão, compreensão por parte dos alunos, desses princípios, desses conceitos?

Estudante $5 \mathrm{Sim}$. Até pra, eu creio que todo curso exige um prérequisito, de partindo de alguma coisa. E acho que todo mundo, como essa é uma idéia nova, tava verde no que diz respeito a isso né. Todo mundo, não tinha uma base que pudesse já entrar sabendo alguma coisa de conceitos de sustentabilidade, conceitos de ética, conceito desses assuntos que estão ligados, que foram trabalhados durante a proposta e como tudo pela primeira vez você sente um pouco de dificuldade. As coisas que a gente devia saber e passar pra outras pessoas, coisas assim mais específicas, mais complexas que a gente tinha que parar e ficar discutindo aquelas coisa mais rudimentares, mais fundamentais né, e não discutir coisas e não trabalhar na forma mais aplicada.

Entrevistadora: Então você acha que esse problema ocorreu por quê? Em decorrência de quê?

Estudante $5 \mathrm{Eu}$ acho, isso não foi um problema do curso. É um problema eu acho que você não ter uma certa capacitação anterior, você não ter um conhecimento já adquirido anteriormente, isso não é um problema. Isso decorre da própria vida. Por se uma coisa nova o pessoal não tava inteirado ainda.

Entrevistadora: Os alunos?

Estudante 5 Os alunos, os alunos! 
Entrevistadora: E os professores?

Estudante 5 Com relação à proposta, falando em relação aos problemas do curso! Também. Eu digo que é os professores, alguns deles passavam maior segurança, outros já demonstravam uma certa, como se tivessem também passando um conteúdo mas não ligando aquele conteúdo à proposta real. Alguns deles passavam : vou falar de política. Tudo bem, falar de política, um exemplo, não que o professor de política não soube conduzir, mas em alguns momentos a metodologia parece que não correlacionou com outras propostas, com outras disciplinas, com os outros conteúdos e acabou, ao invés de se complementarem, acabou por parecer coisas diferentes, parecendo contrárias e que a gente só pode compreender depois no final quando a gente já tinha entendido. Começou a ler mais, a buscar mais conhecimento relacionado com aquilo, que a gente veio a entender que tava ligado tal e foi até rever algumas coisas.

Entrevistadora: E o curso teve virtudes? Quais as principais virtudes desse curso?

Estudante 5 Teve sim. Você passa dez meses trabalhando com uma idéia e você não desistie e aprofundae é porque alguma coisa é a virtude do curso. Eu acho que mesmo as pessoas que foram formadas, capacitadas a repassar alguma coisa, se no futuro não repassar pra alguém, acho que ele mesmo em si próprio já conseguiu modificar alguma coisa. É eu creio que muitos, até quem trabalha com educação acaba passando alguma coisa. Até em decorrência do que foi passado durante o curso. Acho que uma das virtudes maiores do curso foi a questão do relacionamento né. A questão de você entender que meio ambiente não é só ambiente físico, natural e sim tudo o que envolve você. É o seu bem estar de uma maneira geral, o seu ambiente tanto interno, você mesmo com o externo, com o físico, em geral.

Entrevistadora: Como você viu a distribuição e a seqüência das disciplinas? Você tem alguma coisa a falar sobre isso? 
Estudante 5 Eu não sei especificamente que disciplina foi que veio antes. Ocorreu alguns momentos, parece que as disciplinas que lá... é, você dava uma disciplina e lá na frente você pensava: pô! Aquela disciplina aqui seria legal agora, porque se eu soubesse isso que eu sei hoje, talvez eu teria aprendido mais com tal disciplina que passou ou com tal professor assim, assim Eu lembro que a professora Eda Tassara parece que quando ela veio falando cada coisa a gente ficou voando assim. E aí, no finalzinho a gente depois de algumas disciplinas penso: poxa! Se fosse aquela professora agora, pelo tanto que ela passou pra gente, a gente e acho que esperava muito mais, acabava por assimilar muito mais do que pensava.

Entrevistadora: É porque era realmente um diálogo né.

Estudante $5 \mathrm{E}$ ficava centralizado em torno das pessoas que tava mais inteirado da proposta, pessoas que tinha maior conhecimento, que talvez já tivesse vivenciado situações parecida e tal e que já lesse mais, conhecesse mais e tal.

Entrevistadora: E com relação ao período e a duração dos encontros?

Estudante 5 Dos encontros, normal!

Entrevistadora: Você acha que foi suficiente?

Estudante $5 \mathrm{Sim}$. Eu acho que foi suficiente por se tratar de um curso que talvez se a gente fosse buscar um período tal pra desenvolver um trabalho, a gente ficaria aqui 4 anos como a graduação e o trabalho não chegaria ao fim. Por que você sabe que o desenvolvimento sustentável e mais na área de educação ainda você não chega ao final. Você sempre forma pessoas, que forma outros que vão se multiplicando e isso não tem fim.

Entrevistadora: A proposta do curso, ela tinha três eixos que norteavam, os conteúdos, a comunidade aprendizagem e a pedagogia da práxis que seriam os projetos de intervenção educacional. Qual sua compreensão sobre a comunidade aprendizagem? 
Estudante 5 Quando você fala comunidade aprendizagem seria no caso em relação a clientela do curso ou a comunidade ....

Entrevistadora: Como você compreendeu isso. Porque a intenção era que aqui a gente se constituísse enquanto uma comunidade de aprendizagem.

Estudante $5 \mathrm{Ah}$, sim! Minha compreensão da comunidade aprendizagem não sei bem se vou fugir um pouco da resposta correta, mas eu creio que seja seria a própria interação ou a relação da clientela dos alunos do curso com o processo né que foi trabalhado durante o curso. Seria no caso, toda metodologia que foi desenvolvida. Todo processo, mesmo de digo assim, o processo que foi trabalhado, as idéias que foram propostas e tal. É por aí, já que eu tou associando um ao outro, um termo ao outro, então seria mais ou menos isso. Seria uma ligação que objetivou todo o corpo do curso, o processo de adaptação das proposta que foi surgindo nas disciplina, enfim foi a assimilação dos conceito e as idéias.

Entrevistadora: E a integração entre vocês?

Estudante 5 Eu acho que a integração entre nós ...

Entrevistadora: houve integração, não houve?

D.: Eu creio que houve. Agora essa questão de integração no final do curso perdeu um pouco o sentido porque acabou cada um zelando no seu trabalho e no seu projeto e tal, deixando um pouco de lado. Agora, durante as disciplina que foi discutida nos módulos e nos encontros houve integração sim. Não tanto quanto gostaria que existisse, tanto que aconteceu como a maioria parece né. Até porque, depois do curso a gente tem contato com poucos colegas e sabendo que estes tão atuando também, desenvolvendo o que foi aprendido né, desenvolvendo algumas coisa que foi relacionada aqui no curso.

Entrevistadora: Com relação à proposta do curso como é que você vê o projeto de intervenção educacional? Como você vê a idéia do projeto dentro de uma proposta pedagógica de um curso de formação de educadores ambientais? 
Estudante 5 A idéia é muito boa. Agora eu vou falar pra você especificamente do nosso. O nosso a gente teve um pouco de dificuldade, um pouco de receio até no desenvolvimento dessa (...) do próprio trabalho. Até porque, o nosso foi numa comunidade onde tinha pessoas super carentes né e que a gente não poderia simplesmente intervir, tentar ajudar de alguma forma e depois é sei lá, tipo se não der certo larga pra lá e parte pra outro objeto de estudo. Sei lá, não é assim quando se trabalha com pessoas. Então a gente ficou muito preocupado com o pouco período de tempo que a gente tinha, o pouco espaço de tempo e a nossa disposição também, que a gente trabalha e tal, em desenvolver alguma coisa que pudesse ajudar o pessoal, que pudesse fazer eles buscar alguma coisa, que pudesse despertá-los pra alguma coisa. Eu acho que quando você trabalha como formador de idéias não é uma coisa fácil, que você vai lá e manipula. Quando você manipula é uma coisa de laboratório, é diferente e foi essa nossa preocupação, nossa dificuldade maior em não saber ao certo qual seria o resultado que a gente ia obter e se o resultado seria o que ia agradar a comunidade, ia resolver o problema da comunidade. A gente foi tentando acertar em uma situação que a gente não poderia errar. Eu não sei se foi o sentimento de todos os grupos e a gente acabou por às vezes até tentar

Entrevistadora:.: E por que não podia errar?

Estudante $5 \mathrm{Eu}$ sei lá! Eu sei que um pouco até por essa responsabilidade de você ta ali envolvendo pessoas, que sei lá! Trabalhar com pessoas que eu acho sei lá quando a gente trabalha com um lugar, o acesso `a comunidade carente a gente acaba incorporando, acaba sentindo um pouco na pele o que o pessoal passa e acaba tentando, e acho que a gente até fugiu um pouco com a proposta do curso né. A gente acabou sendo, como diz o professor, paternalista né e tentando de alguma forma já ... é não deixa o pessoal mais, acabou fazendo por eles na verdade, algumas coisas, e fugiu um pouco da proposta do curso que é você dar a idéia, você induzir o pessoal a buscar suas coisa, deixar sua idéias. A gente viu que teve que dar um empurrão, mesmo pro pessoal começar a andar. Talvez tenha sido um ponto 
negativo do nosso trabalho né. Talvez, eu acho, que se trabalhar a questão da cultura em sociedades e durante 6 meses assim é você, é você é muito difícil de você conseguir alguma coisa se você não... até por ser uma região extremamente política aqui em Jequié, o pessoal só faz alguma coisa mediante alguém do lado empurrando e talvez se a gente trabalhasse durante muito tempo com eles e ainda que 1 ou 2 da comunidade acabasse por incorporar o sentimento, a sensibilidade de buscar alguma coisa e esses pudessem se multiplicar em outros e outros e o trabalho pudesse fluir ao longo de vários anos. Mas num curto espaço de tempo não foi tão fluente não.

Entrevistadora: E hoje como é que você está se sentindo? Se você sente preparado, potente pra atuar na sociedade em busca de seus ideais?

Estudante 5 Sinto e ultimamente vivo em conflito muito grande na prática profissional. É você busca algumas coisa sem deixar de mão a sustentabilidade, sem deixar de mão a saúde, a cultura. É você sabe correlacionar tudo isso e a dificuldade que você tem em resolve essas coisas mediante toda uma sociedade, toda uma estrutura já formada, e você ter que obedecer algumas regras que não é bem o que você gostaria de seguir. E é um pouco angustiante às vezes quando você tem que tomar algumas atitudes que você não gostaria de tomar. É você às vezes Ter que impor alguma coisa que você gostaria de não impor, que você gostaria de educar talvez né. E em se tratando em fiscalização, que é a minha prática atual, a gente às vezes não educa. A gente educa depois que a gente atua ou autua. A gente primeiro dá uma ferroada e depois a gente vai e passa a mão e acalenteia. Primeiro a gente age e depois você tenta com a ação fazer com que o indivíduo acabe por entender alguma coisa. Mas, geralmente quando a pessoa sofre algum tipo de ação, marca mas volta a fazer de novo alguma coisa. A gente vê muito isso! $\mathrm{Na}$ área que eu trabalho com meio ambiente, meio ambiente no que diz respeito a água, no que diz respeito a saneamento básico, fiscalização, de um modo geral a gente vê muito isso. Você fala, a pessoa vai lá e você fala, fala, fala, e no dia 
que você não fala o cara volta a fazer tudo de novo. Então ele não assimilou coisa nenhuma que você fez. Não passo sensibilidade nenhuma pra ele, ele

Entrevistadora: Então por que vocês não propõe à prefeitura um programa educativo?

Estudante 5 Proposta a gente propõe. Agora o negócio é você desenvolver tudo isso. Até por quê, não é um trabalho sozinho, é um trabalho de uma equipe. E a equipe toda age já com uma certa ... já vem uma certa história aqui em Jequié de impor algumas coisas: não, tem que fazer assim, o senhor vai derrubar isso e vai construir assim, você tem que fazer de tal forma, assim, assim.... Agora, que a gente tá com um projeto educativo em todas as escolas né, um projeto que inclusive a gente inseriu, a gente fez esse ano 100 aulas educativas nas escolas todas, todas as escolas de Jequié e em todos os turnos e a gente distribuiu materiais, falamos sobre educação, saúde e meio ambiente, recebemos algumas coisas de meio ambiente e também passando algumas noções de meio ambiente, cidadania, essas discussões pra que talvez lá no futuro essas pessoas, principalmente as crianças, que a gente trabalha muito com crianças, não venha a sentir, pra que a prática deles no futuro seja diferente da dos pais hoje né. É interessante, a gente trabalhar com comunidades na cidade, quando vai dar aulas, a gente dá palestras em todas as escolas, qualquer buraco a gente vai da aula educativa, a gente mostra algumas coisa né, e aí a criança fala: ha! Meu pai faz isso! Meu pai faz aquilo! E a gente educa a criança pra ela tenta educa o pai em casa. $E$ a gente sabe que não vai conseguir, mas fica naquela criança e a gente espera .... Esse projeto é anual e às vezes a gente vai à escola no ano seguinte e encontra aquela criança em outra série e a gente fala alguma coisa e ela lembra daquilo que a gente disse o ano passado, a gente vê que ela não esqueceu. Eu acho que é por aí que a gente deve seguir. A gente pegar aquilo que aprendeu, aquelas noções que a gente teve e tentar aplicar isso e tentar passar. Não querer que o pessoal incorpore como a gente incorporou aqui. É isso aí. 


\section{REFERÊNCIAS BIBLIOGRÁFICAS}

ANDRADE, F. D. Desejo, alegria e tristeza: o conatus como potência de agir e existir. Cadernos Espinosanos. v 1., p. 7-44, 1996.

ASSMAN, H. Reencantar a educação: rumo à sociedade aprendente. Petrópolis: Vozes, 1998. 251p.

BALILA, D. Memórias e Sonhos de Encarcerados - estudo realizado a partir da idéia de servidão em Espinosa. São Paulo,2000. 250p. Dissertação (Mestrado) - Instituto de Psicologia, Universidade de São Paulo.

BECK, U. O que é globalização? Equívocos do globalismo: respostas à globalização. São Paulo: Paz e Terra, 1999.

BECKER, H.S. Métodos de pesquisa em ciências sociais. 2.ed. São Paulo: Hucitec, 1994. 178p.

BURNHAM, T. F. Complexidade, multirreferencialidade, subjetividade: três referencias polêmicas para a compreensão do currículo escolar. In: BARBOSA, J.G. (Org.) Reflexões me torno da abordagem multirreferencial. São Carlos: EdUFSCar, 1998. 126p.

CABRAL PINTO, F. Heresia Política de Espinosa. Lisboa: Livros Horizonte, 1990. 113p.

CARVALHO, E.A. Tecnociência e complexidade da vida. http://www.cfh.ufsc.br/ dich?Texto\%20do\%20Caderno2021.doc. $\quad(12$ ago. 2002) 
CARVALHO, I. C. M. Educação, meio ambiente e ação política. In: ACSELRAD, H. (Org.). Meio Ambiente e democracia. Rio de Janeiro: IBASE, 1992.

CARVALHO, I. C. M. As transformações na cultura e o debate ecológico: desafios políticos para a educação ambiental. In: PADUA, S.M ; TABANEZ, M.F. (Orgs.) Educação ambiental: caminhos trilhados no Brasil. IPÉ: FNMA: Brasília, 1997. P.. 271-280.

CASTORIADIS , C. As encruzilhadas do Labirinto I. Rio de Janeiro: Paz e terra, 1997. 250p.

CASTORIADIS , C. As encruzilhadas do Labirinto, III : o mundo fragmentado. Rio de Janeiro: Paz e terra, 1992. 267p.

CHAUÍ, M (Org.). Espinosa. 3. ed. São Paulo: Abril Cultural, 1983. 243p. (Coleção Os Pensadores)

CHAUÍ, M. Espinosa: uma filosofia da liberdade. São Paulo: Moderna, 1995. $112 p$.

CHAUÍ, M. Escritos sobre universidade. São Paulo: Ed. da UNESP, 2001. 205p.

DELEUZE, G. Espinoza e os signos. Porto- Portugal: Rés-Editora, s.d. 125p.

DEMO, P. Metodologia Científica em Ciências Sociais. São Paulo: Atlas, 1995. 167p.

DENZIN, N.K. Sociological methods: a sourcebook. Chicago: Aldine, 1970. $590 p$. 
DIAS, M. Na fronteira da cidadania. http://www.ces.fe.uc.pt/coloquio/cid. (23 nov. 2002).

FAZENDA, I (Org). Metodologia da pesquisa educacional. São Paulo: Cortez, 1989. 174p.

FAZENDA, I (Org). A pesquisa em educação e as transformações do conhecimento. Campinas: Papirus, 1997. 147p.

FREIRE, A.M.A Notas. IN: FREIRE, P. Pedagogia da esperança: um reencontro com a pedagogia do oprimido. Rio de Janeiro: Paz e Terra, 1992. P. 205-245.

FREIRE, P. Educação e mudança. Rio de Janeiro: Paz e Terra, 1979.

FREIRE, P. Pedagogia do oprimido. São Paulo: Paz e Terra, 1984.164p.

FREIRE, P. Pedagogia da autonomia saberes necessários à prática educativa. São Paulo: Paz e Terra, 1997. 165p.

FREIRE, P. Pedagogia da Indignação: cartas pedagógicas e outros escritos. São Paulo: Editora UNESP, 2000. 134p.

FUKUYAMA, F. O fim da história e o último homem. Rio de Janeiro: Ed. Rocco, 1992.

FERREIRA, A B.H. Minidicionário da língua portuguesa. 3.ed. Rio de Janeiro: Nova fronteira, 1993. 577p. 
FERREIRA, L.C. ; VIOLA, E. Incertezas de sustentabilidade na globalização. Campinas: Ed. da UNICAMP, 1996. 215p.

GOERGEN, P. Ciência , sociedade e universidade. Revista Educação \& Sociedade, v. 19, n. 63, p.35-47, ago. 1998.

GOHN, M.G. Movimentos e lutas sociais na história do Brasil. São Paulo: Ed. Loyola, 1995.

GONÇALVES, C.W.P. Meio ambiente, ciência e poder: diálogo de diferentes matrizes de racionalidade. In: SORRENTINO, M Ambientalismo e participação na contemporaneidade. São Paulo: EDUC/FAPESP, 2001, p. 135-162. 215p.

GRACIANI, M.S.S. Pedagogia Social de Rua. 2. Ed. São Paulo: Cortez/IPF, 1999. 326p. (Coleção Perspectiva)

GUATTARI, F. As três ecologias. Campinas, SP: Papirus, 1990.126p.

GUATTARI, F ; ROLNIK, S. Micropolítica - cartografias do desejo. Rio de Janeiro: Vozes, 1999. 230p.

GUTIERREZ, F. Educação como práxis política. São Paulo: Summus, 1988. $125 p$.

GUTIERREZ, F.; PRADO, C. Ecopedagogia e cidadania planetária. São Paulo: Cortez; Instituto Paulo Freire, 1999. 128p.

HARDT, M. Giles Deleuze: um aprendizado em filosofia. São Paulo: Ed. 34, 1996. 189p. 
HERCULANO, S. C.; PORTO, M.F.S.; FREITAS, C.M. (Orgs). Qualidade de vida e riscos ambientais. Niterói: Ed. UFF, 2000.

HOBSBAWM, E. Era dos Extremos. São Paulo: Companhia das Letras, 1995. $345 p$.

HOPPEN, S.R.; LAPOINTE, L.; MOREAU, E. Um guia para avaliação de artigos de pesquisa em sistemas de informação. www:http/read.adm.ufrgs.br/read03/ (15 nov. 2002).

HUBERMAN, A; MILES, M. data management and analysis methods. In: DENZIN, N. ; LINCOLN, Y. (Ed.) Handbook of Qualitative research. California: Sage, 1994. Cap. 27, p.428-444.

IANNI, O. A Sociedade Global. 5. ed. Rio de Janeiro: Civilização Brasileira, 1997. 183p.

INSTITUTO ECOAR PARA A CIDADANIA. Agenda 21 do pedaço. São Paulo: Consórcio Cógito; Instituto Ecoar para a Cidadania; SVMA- Secretaria Municipal do Verde e do Meio Ambiente, 1997. 16p.

JANESICK, V. The dance of qualitative research design. In: DENZIN, N. ; LINCOLN, Y. (Ed.) Handbook of Qualitative research. California: Sage, 1994. cap. 12 p.209-219.

JAPIASSÚ, H. A crise das ciências humanas. In: FAZENDA, I. (Org.) A pesquisa em educação $e$ as transformações do conhecimento. Campinas, SP: Papirus, 1997. Cap. 5. 159p.

LEITE, D. (Org.). Pedagogia universitária: conhecimento, ética e política no ensino superior. Porto Alegre: Ed. Universidade/UFRGS, 1999. 182p. 
LEITE, D.; BRAGA, A M. ; GENRO, M.E. Avaliação institucional e os desafios da formação docente na universidade pós-moderna. http://www2.uca.es/HEURESIS (12 ago. 2002).

LEITE, I. Emoções, sentimentos e afetos (uma reflexão sócio-histórica). Araraquara: JM Editora, 1999. 112p.

LEIS, H.R. O labirinto: ensaios sobre ambientalismo e globalização. São Paulo: Gaia; Blumenau: ed. da FURB, 1998. 225p.

LIMA. G. F. C. Crise ambiental, educação e cidadania: os desafios da sustentabilidade emancipatória. IN: LOUREIRO, C. F. B. (Org.). Educação ambiental: repensando o espaço da cidadania. São Paulo: Cortez, 2002. $255 p$.

LUDKE, M.E \& ANDRÉ, M.E.D.A. Pesquisa em educação: abordagens qualitativas. São Paulo: editora Pedagógica e Universitária, 1986.203p.

MAFFESOLI, M. No fundo das aparências. Petrópolis, RJ: Vozes, 1996. 350p.

MCLAREN, P. Utopias provisórias: as pedagogias críticas num cenário póscolonial. Petrópolis, RJ: Vozes, 1999.243p.

MCLAREN, P.; FARAHMANDPUR, R. Pedagogia revolucionária na globalização. Rio de Janeiro: DP \& A, 2002. 117p.

MINAYO, M.C.S (Org.). Pesquisa Social - teoria, método e criatividade. 14. ed. Petropolis-Rj: Ed. Vozes, 1999. 80p. 
MORIN, E. Os sete saberes necessários à educação do futuro. São Paulo: UNESCO. 2000. 118p.

MORIN, E. ; LE MOIGNE, JL. A inteligência da complexidade. São Paulo: Peirópolis, 2000. 263p. (Série nova cosnciência)

PATTON, M.Q. Qualitative evaluation and research methods. New York: Sage, 1990. 532p.

PRYGOGINE, I. O fim das certezas. São Paulo: Ed. da UNESP, 1996. 199p.

SACARDO, G.A. Participação e Subjetividade num programa de Educação Ambiental. São Paulo, 2001. 148p. Tese (Doutorado) - Faculdade de Saúde Pública, Universidade de São Paulo.

SANTOS, B.S. Um discurso sobre as ciências. 6. ed. Porto: Edições Afrontamento, 1993. 165p.

SANTOS, B.S. Introdução a uma ciência pós-moderna. Rio de Janeiro: Graal, 1989. 176p.

SANTOS, B.S. Pela mão de Alice. O social e o político na pósmodernidade. 3. ed. São Paulo: Cortez,1997. 347p.

SANTOS, B.S. Para um novo senso comum : a ciência, o direito e a política na transição paradigmática. Vol.I A crítica da razão indolente: contra o desperdício da experiência . 3 ed. São Paulo: Cortez. 2001. v.2. 415p.

SANTOS, M. Por uma outra globalização: do pensamento único à consciência universal. 3. ed. Rio de Janeiro: Record,2000. 286p. 
SAWAIA, B.B.A emoção como locus de produção do conhecimento - uma reflexão inspirada em Vygotsky e no seu diálogo com Espinosa.

http://www.fae.unicamp.br/br2000/trabs/1060.doc (12 ago. 2002).

SAWAIA, B.B. Participação Social e Subjetividade. In: SORRENTINO, M Ambientalismo e participação na contemporaneidade. São Paulo: EDUC/FAPESP, 2001, p. 115-134. 215p.

SCHERER-WARREN, I. Redes de Movimentos Sociais. São Paulo: Ed. Loyola, 1996. 214p.

SCRUTON, R. Espinosa. São Paulo: Ed. UNESP, 2000. 67p.

SORRENTINO, M. Crise ambiental e Educação. In. QUINTAS, J.S. (Org.) Pensando e Praticando a educação Ambiental na Gestão do Meio Ambiente. Brasília: Ed. IBAMA, 2000. cap.3, p. 34-42. 145p.

SPOZATI, A. Movimentos utópicos da contemporaneidade. In: SORRENTINO, M. Ambientalismo e participação na contemporaneidade. São Paulo: EDUC/FAPESP, 2001, p. 11-40. 215p.

TASSARA. E. Educação ambiental, referenciais históricos, teóricos e formação de redes. In: INESC; ECOAR; APRV. Cadernos do IV Fórum de Educação Ambiental. Rio de janeiro, 1997. 206p.

TRAJBER, R.; MANZOCHI, L.H. Avaliando a Educação Ambiental no Brasil: materiais impressos. São Paulo: Gaia, 1996. 230p. 
TRISTÃO, M. Rede de relações: os sentidos da educação ambiental na formação de professores/as. São Paulo, 2001. 158p. Tese (Doutorado). São Paulo: Faculdade de Educação, Universidade de São Paulo.

UESB. Projeto de recredenciamento. Vitória da Conquista, 2002. 103p.

YIN, R.K. Case study research: design and methods. Tradução e síntese de R. L. Pinto. http://www.fea.usp.br/metodologia/estudo_caso.asp/ (21 nov. 2001). 